\title{
Archaeological Excavation of the Priest Quarters, Mission San Francisco de la Espada, 41BX4, San Antonio, Texas
}

Jose E. Zapata

Center for Archeological Research, University of Texas at San Antonio

Maureen J. Brown

Center for Archaeological Research

Jeffery J. Durst

Center for Archaeological Research

Follow this and additional works at: https://scholarworks.sfasu.edu/ita

Part of the American Material Culture Commons, Archaeological Anthropology Commons, Environmental Studies Commons, Other American Studies Commons, Other Arts and Humanities Commons, Other History of Art, Architecture, and Archaeology Commons, and the United States History Commons

Tell us how this article helped you.

This Article is brought to you for free and open access by the Center for Regional Heritage Research at SFA ScholarWorks. It has been accepted for inclusion in Index of Texas Archaeology: Open Access Gray Literature from the Lone Star State by an authorized editor of SFA ScholarWorks. For more information, please contact cdsscholarworks@sfasu.edu. 


\section{Archaeological Excavation of the Priest Quarters, Mission San Francisco de la Espada, 41BX4, San Antonio, Texas}

\section{Creative Commons License}

\section{(c) (1) \&}

This work is licensed under a Creative Commons Attribution-NonCommercial 4.0 International License 


\section{Archaeological Excavation of the Priest Quarters,}

Mission San Francisco de la Espada, 41BX4,

\section{San Antonio, Texas}

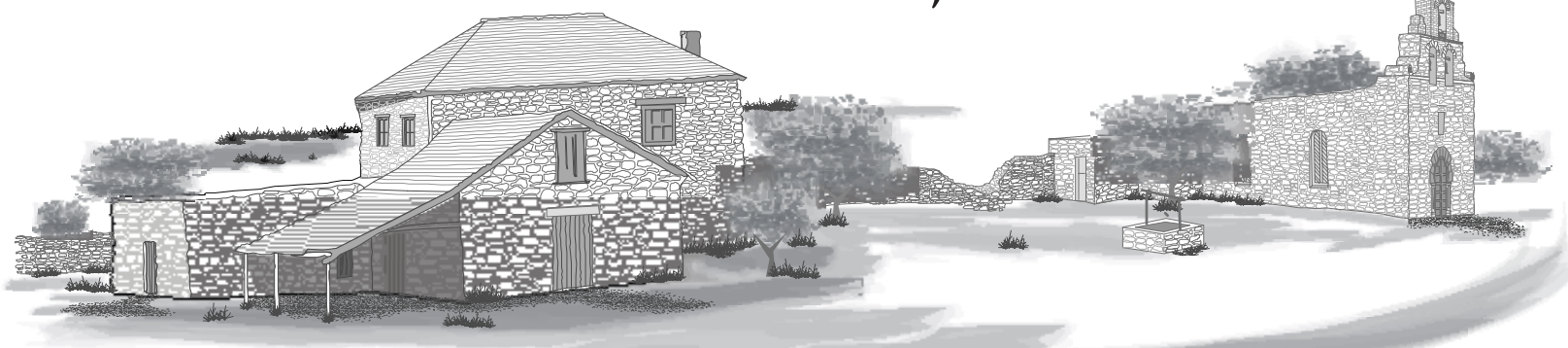

José E. Zapata, Maureen J. Brown,
and Jeffrey J. Durst

with contributions by

Anne A. Fox, Barbara A. Meissner,

Kristi H. Miller, and Steve A. Tomka

Center for Archaeological Research The University of Texas at San Antonio Archaeological Survey Report, No. 295 2000

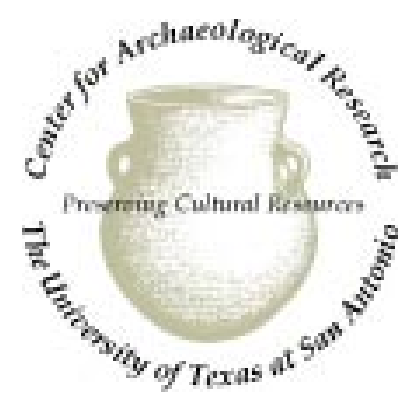




\title{
Archaeological Excavation of the Priest Quarters, Mission San Francisco de la Espada, 41BX4, San Antonio, Texas
}

\author{
José E. Zapata, Maureen J. Brown, \\ and Jeffrey J. Durst \\ with contributions by \\ Anne A. Fox, Barbara A. Meissner, \\ Kristi H. Miller, and Steve A. Tomka
}

\section{Robert J. Hard and C. Britt Bousman Principal Investigators}

Texas Antiquities Permit No. 2076

Ccopyright 2000

Center for Archaeological Research

The University of Texas at San Antonio

Archaeological Survey Report, No. 295 
The following information is provided in accordance with the General Rules of Practice and Procedure, Chapter 41.11 (Investigative Reports), Texas Antiquities Committee:

1. Type of investigation: Excavation, mitigation, data recovery and archival research.

2. Project name: Espada Southwest Corner Wall/Mission Espada Priest Quarters

3. County: Bexar.

4. Principal investigators: Robert J. Hard and C. Britt Bousman.

5. Name and location of sponsoring agency: San Francisco de la Espada/Catholic Diocese of San Antonio, 10040 Espada Road, San Antonio, Texas 78214

6. Texas Antiquities Permit No.: 2076

7. Published by the Center for Archaeological Research, The University of Texas at San Antonio, 6900 N. Loop 1604 W., San Antonio, Texas 78249-0658, 2000

A list of publications offered by the Center for Archaeological Research is available. Call (210) 458-4378; write to the Center for Archaeological Research, The University of Texas at San Antonio, 6900 N. Loop 1604 W., San Antonio, Texas 78249-0658; e-mail to car@lonestar.utsa.edu; or visit CAR's web site at http://car.utsa.edu/. 


\begin{abstract}
The following report is the result of two projects completed by the Center for Archaeological Research, of The University of Texas at San Antonio for San Francisco de la Espada/Catholic Diocese of San Antonio and J. T. Michel, Inc., under Texas Historical Commission Permit Number 2076. The investigations were conducted at Mission San Francisco de la Espada, San Antonio, Bexar County, Texas (41BX4).

The initial investigation was conducted in November 1998, prior to the planned installation of electrical lines along the southwest corner of the Convento (complex of structures grouped around a patio area), while the additional excavations of July and August 1999, were conducted to coincide with restoration work being conducted on the Chapel and Priest Quarters. Additional investigations were also conducted in July and August 1999, along the southern-most walls of the Priest Quarters prior to the installation of new foundation piers and beams designed to stabilize the existing wall foundations. The excavations affected the exterior walls of the Convento; an area $1 \mathrm{~m}$ wide by $1 \mathrm{~m}$ deep, and $25.2 \mathrm{~m}$ long. The monitoring portion conducted in October and November 1999, focused on unexcavated areas along walls that were exposed during the stabilization work. During the course of the investigations exposed foundations and features were documented, with specific attention to mode of construction and condition. The excavations resulted in the recovery of a variety of Colonial and post-Colonial artifacts including ceramics, lithics, glass, metal, and animal bone. These excavations which supplied the opportunity for the recovery of valuable cultural data, also revealed noticeable differences in wall foundation construction and reconstruction, which strongly suggest at least two distinct construction sequences.
\end{abstract}




\section{Contents}

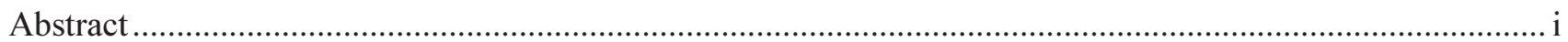

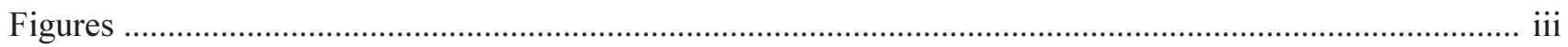

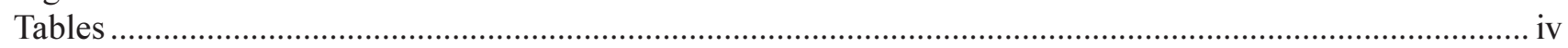

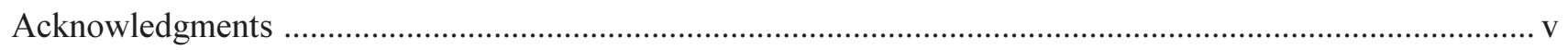

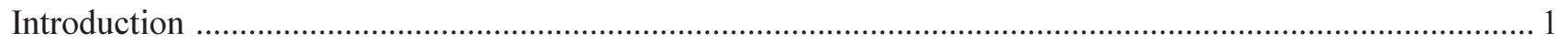

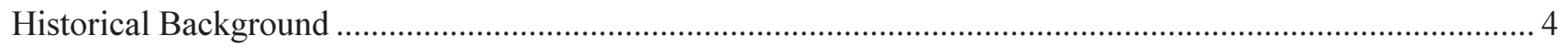

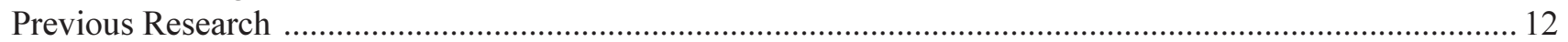

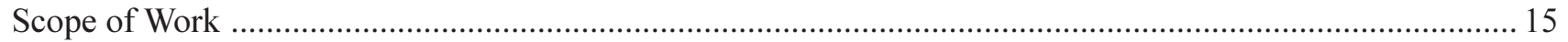

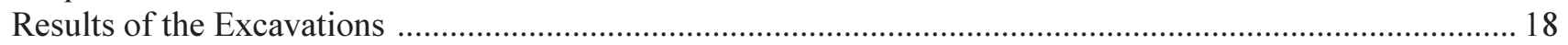

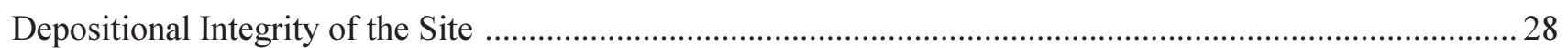

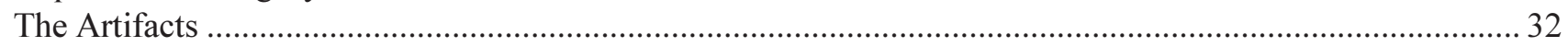

Chipped Stone, Ceramics, Other Artifact Types and Faunal Remains ................................................... 32

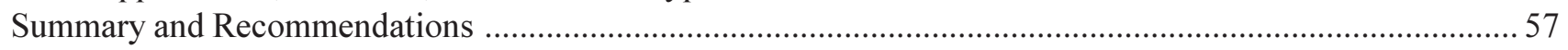

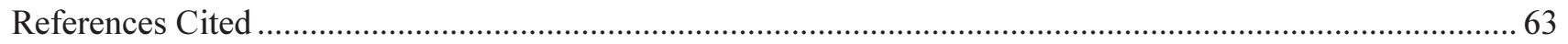

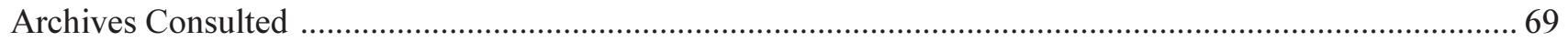

Appendix A

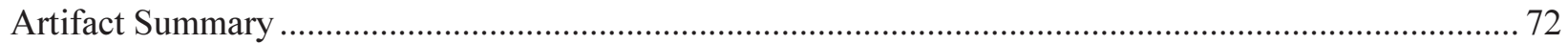

Appendix B

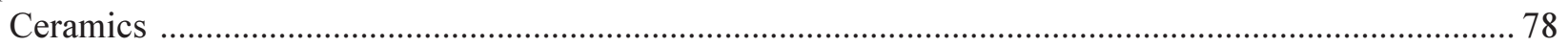

Appendix C

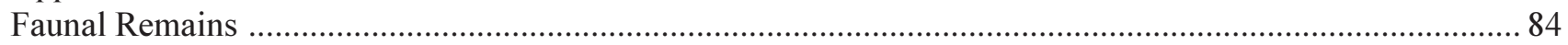




\section{Figures}

Figure 1. Location of Mission San Francisco de la Espada, San Antonio, Texas. ........................................... 1

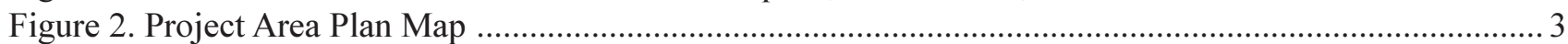

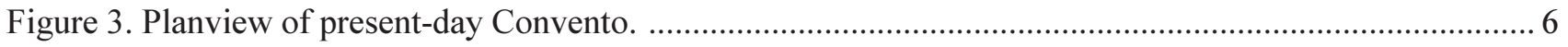

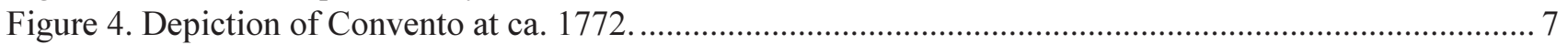

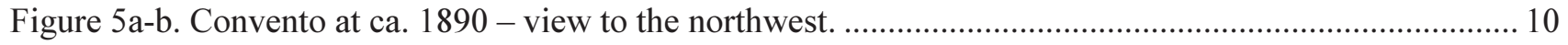

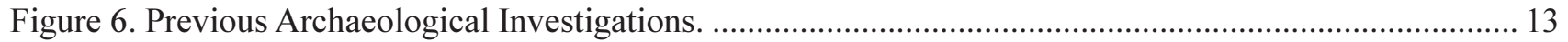

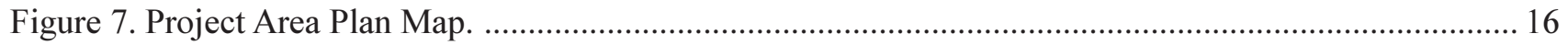

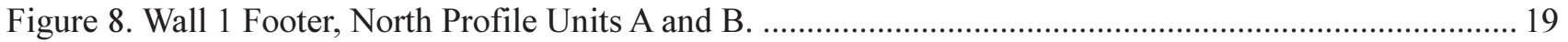

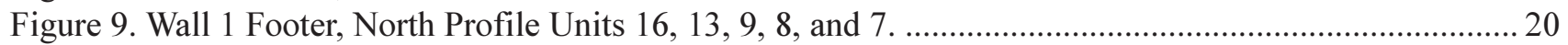

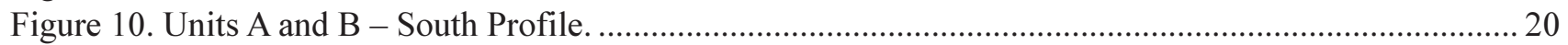

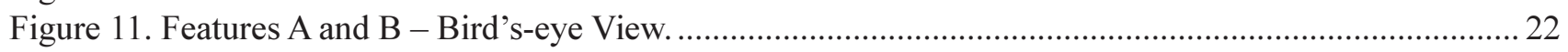

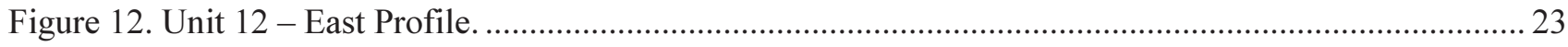

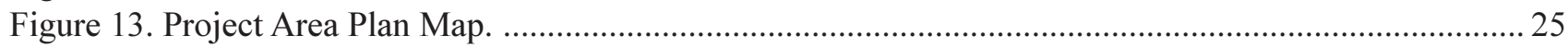

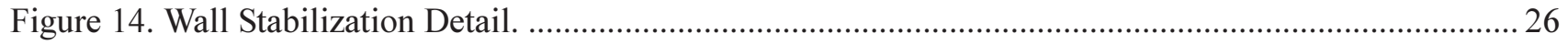

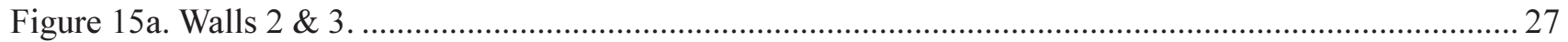

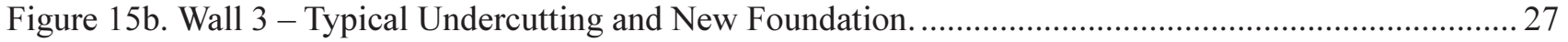

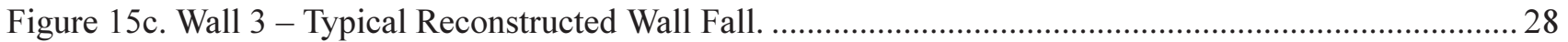

Figure 16. Density of Kitchen and Construction Artifacts, Walls 1 and 2. ..................................................2 29

Figure 17. Density of Kitchen and Construction Artifacts, Walls 3 and 4................................................. 30

Figure 18. Walls 1 and 2 Ceramics - Whiteware vs. Goliad ware. ........................................................ 31

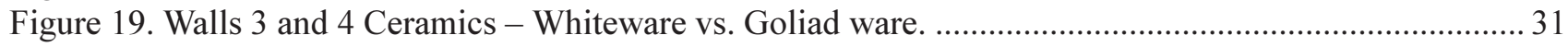

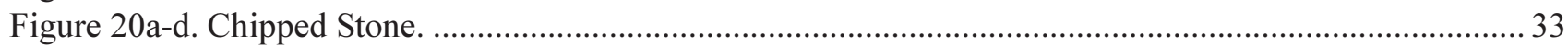

Figure 21. Distribution of Unmodified Lithic Debitage by Level............................................................ 36

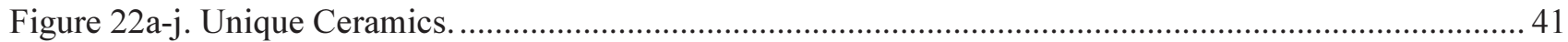

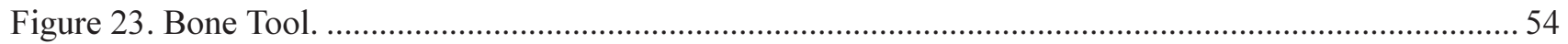

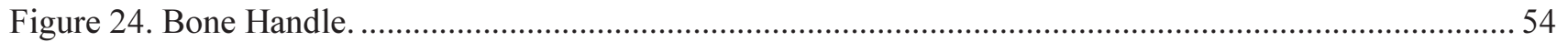

Figure 25. Two views of severe pathology in the elbow joint of a sheep from Unit 3. ................................ 55

Figure 26. Proximal end of a sheep humerus with deep cut, shown in a lateral view. ................................... 56 


\section{Tables}

Table 1. Demographic data - Mission Espada, 1737 to 1809 ....................................................................... 5

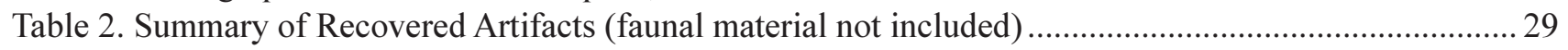

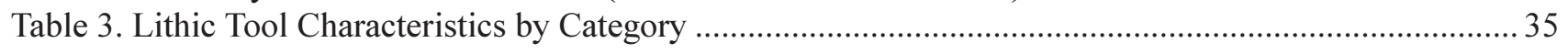

Table 4. Breakdown of Mean Debitage Size Characteristics by Level ........................................................ 37

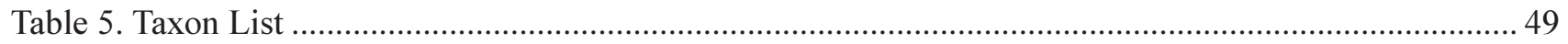

Table 6. Bone Identified to the Genus Taxonomic Level ........................................................................ 51

Table 7. Percent of Total NISP Bone Weight for Selected Taxa ................................................................5 52

Table 8. Highest Ranking Genera by NISP, MNI, and Bone Weight ....................................................... 52

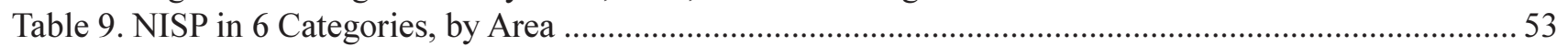

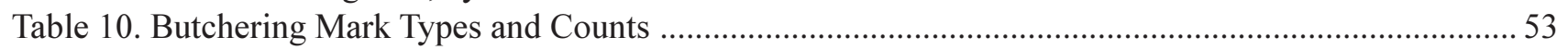

Table 11. Comparison of the NISP of Selected Genera from Three Mission sites in South Texas ................... 57

Table 12. Percentage of Total NISP Bone Weight in Six Categories Compared to the Current Project ........... 58

Table 13. Comparison of Levels Above and Below $40 \mathrm{~cm}$ in Units Adjacent to Walls 3 and 4 .....................59 


\section{Acknowledgments}

The authors wish to acknowledge the support and assistance of the staff of Ford, Powell and Carson, especially John Amos and Carolyn Peterson who provided a great deal of insight during these two projects. We would also like to acknowledge David Resendez and his staff from J. T. Michel, Inc. for their support and patience. Many thanks to Brother Jerome and Father Larry who were patient and understanding of our efforts outside their home, as well as Reverend Balthasar Janacek, Archdiocesan Director, Old Spanish Missions. Thanks also to the on-site staff of the National Parks Service who were very supportive during our presence at the site.

The archival research could not have been accomplished without the assistance of Rosalyn Rock of the San Antonio Missions, National Historical Park; Beth Dodd of the Alexander Architectural Archives, The University of Texas at Austin; the staff of the Catholic Archives in Austin; and Tom Shelton of the Institute of Texan Cultures, The University of Texas at San Antonio; as well as the staff of the Archdiocese of San Antonio.

We would also like to thank the support team at the Center for Archaeological Research, Robert J. Hard, director and C. Britt Bousman, associate director were vital to the success of this project and they offered, as always, a great deal of valuable insight to our investigations. Tony Lyle, Ruth Mathews, Chris Horrell, Clemente Murguía, Gloria Murguía, Brian Langner, Kristi Miller, Preston McWhorter, Ricky Robinson, Richard Jones, Patricia Moses and Laura Burgess made up the field crews on the two respective projects. Thanks are also due to our

graphics staff, Bruce Moses and Richard Young, and our editor, Maryanne King. For their insightful contributions, thanks are also due to Anne Fox, Barbara Meissner, Kristi Miller, and Steve Tomka. 



\section{Introduction}

In November 1998, the Center for Archaeological Research (CAR) of The University of Texas at San Antonio (UTSA) performed archaeological excavations at Mission San Francisco de la Espada, San Antonio,
Bexar County, Texas (Figure 1) prior to the installation of electrical lines in the Convento of Mission Espada. CAR was contracted by the Archdiocese of San Antonio to excavate a $1 \times 2$ meter area along the

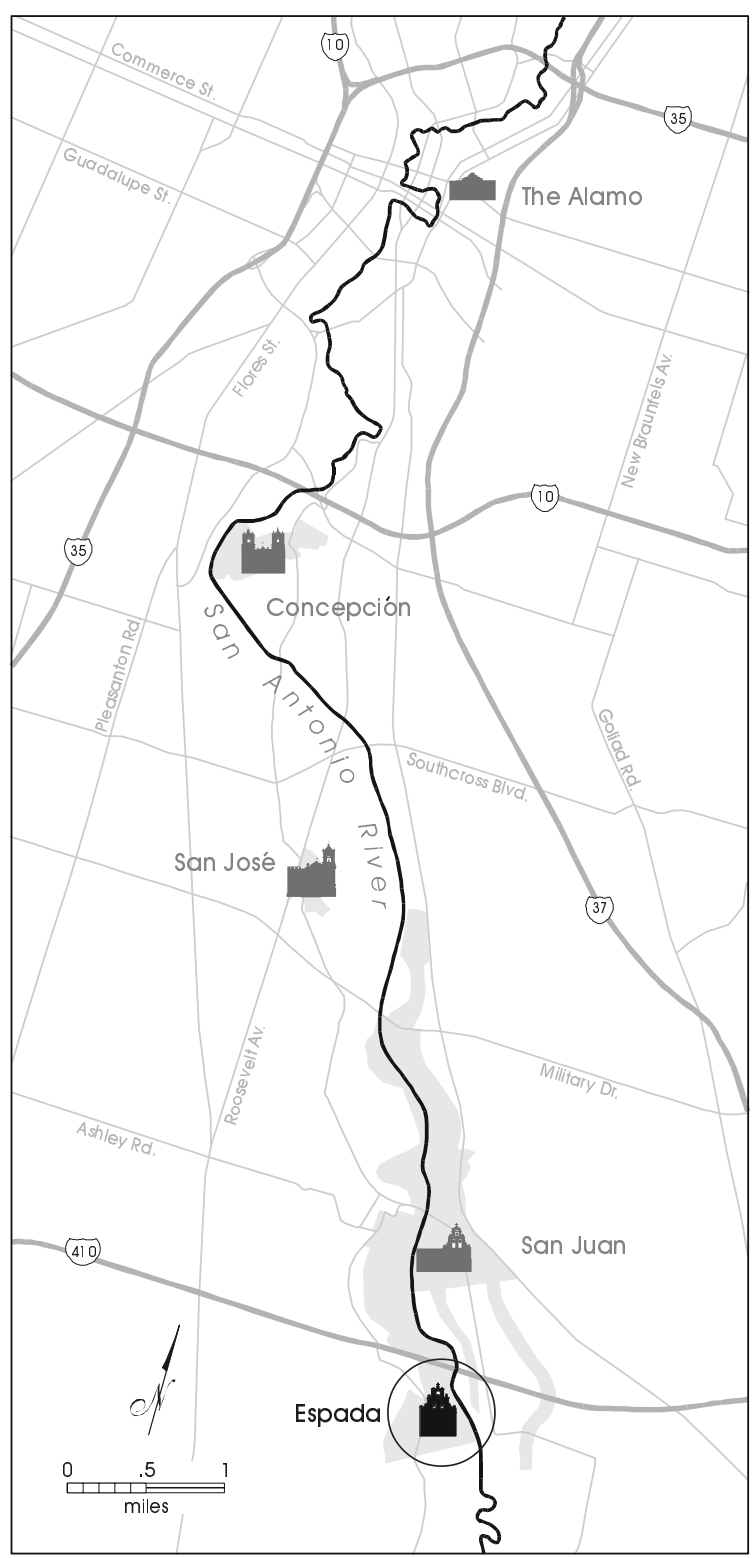

Figure 1. Location of Mission San Francisco de la Espada, San Antonio, Texas. 
southwest corner wall of the Priest Quarters. This investigation was supervised by Maureen J. Brown, of CAR-UTSA, in compliance with Texas Antiquities Permit Number 2076. The fieldwork was conducted between November 9 and November 18, 1998.

In July 1999, CAR-UTSA entered into a contract with J. T. Michel, Inc. to investigate the area along the southern walls of the Priest Quarters. This work was to coincide with restoration work being performed on the Chapel and Priest Quarters. During July and August 1999, additional excavations were conducted along the southern-most wall of the Priest Quarters. These excavations were conducted in advance of the installation of foundation piers and beams, which were to be installed directly beneath the existing wall foundations as part of a wall stabilization project, and included the area previously investigated by Brown.

These additional investigations were designed to recover data from Spanish Colonial period deposits that might be impacted by the proposed work. The fieldwork was conducted between July and August 1999, and supervised by Jeffrey J. Durst of CAR-UTSA. The investigation included archival research relating to the construction and reconstruction sequence of the Convento, as well as the monitoring of the work in progress, between October and November, 1999. The investigations were considered to be an extension of the earlier work conducted by Brown, and work proceeded under an amendment to Texas Antiquities Permit Number 2076.

The work conducted by Brown in November 1998, indicated that there were intact Colonial period deposits found in association with an apparent Colonial period wall foundation, located beneath the existing southern-most wall of the Priest Quarters. The Brown investigation also revealed a probable wall (stone alignment), the origins of which remained uncertain at that time. Based on Brown's preliminary report, a data recovery program was designed to mitigate the anticipated impact of the proposed wall stabilization work.

The July and August 1999 excavations consisted of 14 1-x-1 meter units, one 1-x-1.5 meter unit, and one 1.3-x-1.4 meter unit. These units were located along the edges of the five existing southern-most walls of the Priest Quarters. Figure 2 represents an isolated view of the project area, and indicates the units which were excavated in 1998 (A and B) and those excavated in 1999 (1-16). In addition to these excavations, a monitoring program was also designed for the unexcavated areas along Walls 4 and 5. This monitoring work was carried out during the months of October and November 1999.

The excavation and monitoring activities resulted in the recovery of a variety of Colonial and postColonial artifacts including ceramics, lithics, glass, metal, chipped stone, and animal bone. These excavations exposed $25.2 \mathrm{~m}$ of wall foundation, including $6 \mathrm{~m}$ along Walls 4 and 5 that were excavated by the general contractor. This amounted to the exposure of the entire length of the south-end walls. The exposed foundations and associated features were illustrated and also photo-documented. This investigation revealed noticeable differences in wall foundation construction, which strongly suggests at least two distinct construction sequences. 


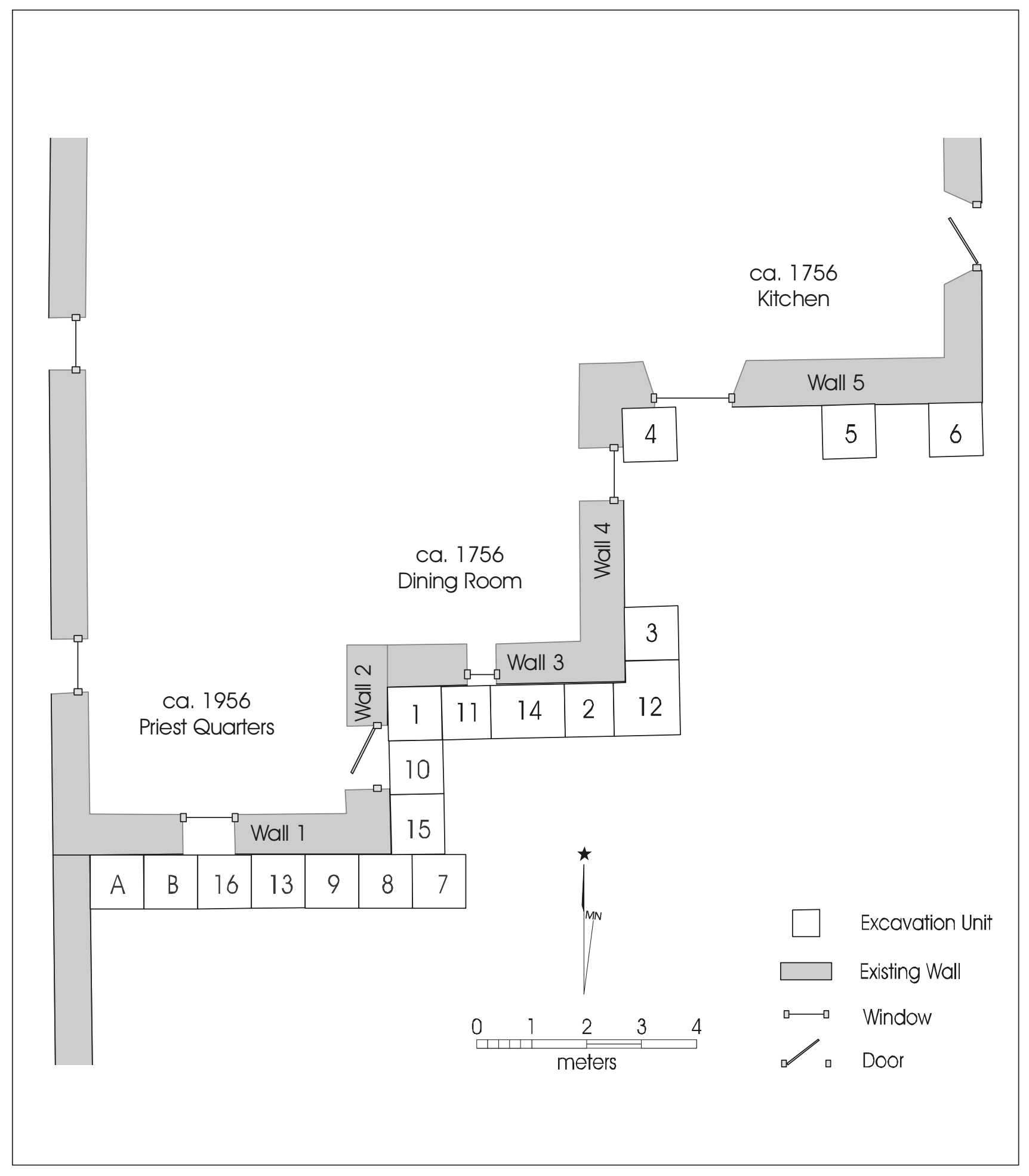

Figure 2. Project Area Plan Map 


\section{Historical Background}

Our interest is in detailing the site occupation history and construction sequence of the Convento. The data presented below is taken from a review of the literature, and includes the work of Escobedo (1984), Habig (1968), and Schuetz (1980). Additional data was taken from the Land Tenure Study of the San Antonio Missions (Almaráz 1982), and from Of Various Magnificence, The Architectural History of the San Antonio Missions, Volumes One and Two (Ivey et al. 1990; Thurber et al. 1993). These last three studies were especially useful. The archival data was gleaned from four primary sources: the Catholic Archives of Texas in Austin (CAT); the Archdiocese of San Antonio (ASA); the Institute of Texan Cultures (ITC), and an examination of the Harvey P. Smith drawings of San Antonio Missions, 1929-1957 which are located in the Alexander Architectural Archive, Architecture and Planning Library, The University of Texas at Austin (AA-APL).

\section{Beginnings}

Mission San Francisco de la Espada was originally established in 1690 among the Tejas Indians in east Texas. The establishment of the mission was in conjunction with the fifth expedition into Texas by the governor of the Province of Coahuila, Alonso de León (Foster 1995:33). León, along with Fr. Damian Massanet and three other friars from the Apostolic College of Querétaro established the mission on May 24, 1690, about seven miles west of the Neches River on San Pedro Creek (Habig 1968:192). This mission was abandoned in October of 1693 and was not reestablished until July 1716, when it was relocated about ten miles to the east on Bowles Creek and renamed Nuestro Padre San Francisco de los Tejas (Habig 1968:195). This mission failed in the summer of 1719 when the French drove the Spaniards out of east Texas.
In August of 1721, the mission was re-established on the same Bowles Creek site and renamed San Francisco de los Neches by the expedition of the Marqués de Aguayo, with the assistance of a detachment of Spanish soldiers and Fr. José Guerra. As a result of this expedition, the Franciscan College of Querétaro established three missions in east Texas, and the College of Zacatecas established another three. In 1729, the College of Querétaro decided to relocate its three missions to San Antonio. The moveable property of mission San Francisco de los Neches was relocated to the west side of the San Antonio River on March 5, 1731 and the mission was renamed San Francisco de la Espada (Habig: 202-204).

Mission Espada was the southern-most of the five San Antonio missions and was thus the most susceptible to attack from raiding Indian groups (see Figure 1). Frequent raids by Apaches continued throughout the early years of the mission. Despite these depredations, the missionaries and neophytes persisted and a small frontier settlement emerged.

The earliest census for Mission Espada was recorded in 1737 and the population numbered 108. The highest census recorded lists 207 in 1762, with a low count of 24 in 1809. The mission population fluctuated considerably between 1737 and 1809 , with a 50 percent decrease between $1789(n=93)$ and $1790(n=46)$ (see Table 1, Demographic Data). Although this extraordinary decrease was evident at all five missions, this decline was owed to a bureaucratic problem, rather than some calamity. Schuetz (1980:191-95) attributes this decrease to a change in the reporting criterion of the 1790 census, which required that only those Indians actually living inside the mission walls be included in the census. What this suggests is that by the late1780 s, at least half of the neophytes were living outside the mission walls. 
Smith (1980b) suggested that the mission developed in at least four phases, and that these phases might relate to fluctuations in the indigenous-resident population that provided the construction labor. Considering Ivey's (1990) suggestion of a 1731 to 1772 range for mission development, there may be some substance to Smith's idea. To illustrate, Table 1 shows that the highest average adult population for this mission was 127, between 1745 and 1777. This raises the question, Would the 1745-1777 labor pool be sufficient to support the mission's multi-faceted ventures? The oftcited enterprises included:

1) The farming and ranching of assorted crops and herds;

2) The construction and maintenance of an elaborate irrigation system; and

3) The construction of numerous masonry structures, outbuildings and other projects; (see Almaráz 1982; Escobedo 1984; Habig 1968; Ivey 1990).

Between 1737 and 1740, the average adult population was 73 (see Table 1). This low number would account for the fact that the early mission structures were jacales. These temporary structures were constructed in an expedient manner, utilizing readily available perishable materials (Ivey et al. 1990; Schuetz 1980). These early buildings would have eventually been replaced by stone structures, but according to Schuetz (1980:244-45), missions San Juan and Espada were never able to replace all of the jacales. Schuetz describes a typical Colonial period jacal as a small palisade-constructed structure, rectangular in form, and with a pitched roof (for a detailed description, see Graham 1978:38-45). It was not until the mid1740 s that any substantial structures are recorded at Mission Espada.
Table 1. Demographic data - Mission Espada, 1737 to 1809

\begin{tabular}{|l|c|c|c|c|c|}
\hline Year & $\begin{array}{c}\text { Total } \\
\text { Population }\end{array}$ & $\begin{array}{c}\text { Adult } \\
\text { Population }\end{array}$ & $\begin{array}{c}\text { Adult } \\
\text { Males }\end{array}$ & $\begin{array}{c}\text { Adult } \\
\text { Females }\end{array}$ & Children \\
\hline 1737 (1), (2) & 108 & 69 & 35 & 34 & 39 \\
\hline 1740 (1), (2) & 120 & 77 & 39 & 38 & 43 \\
\hline 1745 (1), (2) & 204 & 131 & 67 & 64 & 73 \\
\hline 1756 (1), (2) & 200 & 128 & 65 & 63 & 72 \\
\hline 1762 (1), (2) & 207 & 132 & 67 & 65 & 75 \\
\hline 1772 (2) & 174 & 134 & 68 & 66 & 40 \\
\hline 1777 (1), (2) & 174 & 111 & 57 & 54 & 63 \\
\hline 1783 & 96 & 60 & 32 & 28 & 36 \\
\hline 1784 (1), (2) & 98 & 63 & 32 & 31 & 35 \\
\hline 1785 (1), (2) & 115 & 74 & 38 & 36 & 41 \\
\hline 1786 (1), (2) & 144 & 92 & 47 & 45 & 52 \\
\hline 1787 (1), (2) & 81 & 52 & 27 & 25 & 29 \\
\hline 1789 (1), (2) & 93 & 60 & 31 & 29 & 33 \\
\hline 1790 & 46 & 32 & 17 & 15 & 14 \\
\hline 1791 (1), (2) & 46 & 29 & 15 & 14 & 17 \\
\hline 1792 (1), (2) & 48 & 32 & 15 & 17 & 16 \\
\hline 1794 (1), (2) & 45 & 29 & 15 & 14 & 16 \\
\hline 1809 (2) & 24 & 19 & 10 & 9 & 5 \\
\hline $\begin{array}{l}\text { Notes: Data derived from Habig (1968:207-18) \& Schuetz (1980:180-85). } \\
\text { of Extrapolations for adult population computed at 64\% of Total, and (2) Ratio of males to females computed at } 51: 49\end{array}$ \\
\hline
\end{tabular}

It is also believed that the master mason, Antonio de Tello of Zacatecas, designed and provided some supervision to the construction of the churches at missions Concepción, Valero, Espada, and San Juan, respectively. Tello's work is said to have been carried out between 1738 and 1744 , which includes the length of his stay in San Antonio (Ivey et al. 1990). The first church at Espada was never fully completed but Tello managed to partially construct the sacristy, which was then put into use as a temporary church at ca. 1745. Since the church was never completed, the sacristy eventually became the functioning chapel of Espada and has maintained this use up until the present day. 


\section{The Convent (Convento)}

More significant to our current research is the construction and reconstruction history of the Convento, a complex of structures grouped around a patio. A typical Convento is comprised of the friary (Priest quarters), hospice, office, infirmary, kitchen, refectory (dining room) and privy (Ivey et al. 1990). In the case of Mission Espada, this complex also includes the chapel (see Figure 3).

At present, the structures that comprise the Convento are considered non-secular (religious) buildings. In accordance with the Cooperative Agreement of 1983, between the Archdiocese of San Antonio and National Park Service, the Convento falls under the disposition of the Archdiocese of San Antonio (see Ivey et al. 1990:467-70). As will be demonstrated in the resulting research notes, the historical fabric of the ca. 1756 Convento has been considerably altered over the course of its history. The present-day configuration of the Convento is depicted in Figure 3, most of these alterations were accomplished in the 1950 s by the architect, Harvey P. Smith.

The structures associated with the Convento were among the first in the series constructed at Mission Espada, and date to between 1745 and 1756. Smith (1980b) suggests that the mission may have been constructed in four phases, but fails to commit to specific time-lines. By the same token, Ivey only goes so far as to state that "the buildings followed a very orderly process of development between 1731 and 1772" (1990:195). Smith and Ivey suggest that the first phase of construction would have consisted of the sacristy (present-day chapel), friary, and associated stone walls.

The Convento appears to have taken shape with the construction of the sacristy, which subsequently became the chapel. Construction then proceeded to the friary, which consisted of two offices on the ground floor and two rooms above, all completed sometime between 1745 and 1756 (Habig 1968; Ivey et al. 1990). The friary would have served as a residence for the priests and as guest quarters. Ivey suggests that this two-story friary would have had a staircase and that the privy would have been located on the lower level, underneath the landing. Habig's account of a 1756 report authored by Fr. Ortiz describes the recently completed friary as a two-story building with four rooms. This same report noted that the sacristy, or chapel, had also been completed. Habig (1968) also relates that in 1756, the neophytes were still housed in jacales but that these were being replaced with stone structures.

According to the 1762 inventory (Habig 1968), the friary consisted of three rooms on the lower level and four rooms on the top floor. An arcade, which flanks the friary, is also mentioned at this time. By 1772, the friary consisted of four offices on the ground floor, with a row of cells fronted by a corridor on the second floor (Ivey et al. 1990). Adjoining the friary to the south and to the east, were two additional structures; the kitchen and the dining room (antecocina). These rooms are believed to be contemporaneous with the friary and chapel. Figure 4 is taken from Ivey et al. (1990) and depicts the Convento at ca. 1772. It shows a floorplan for the two-story friary, and the current project area as it relates to this early configuration.

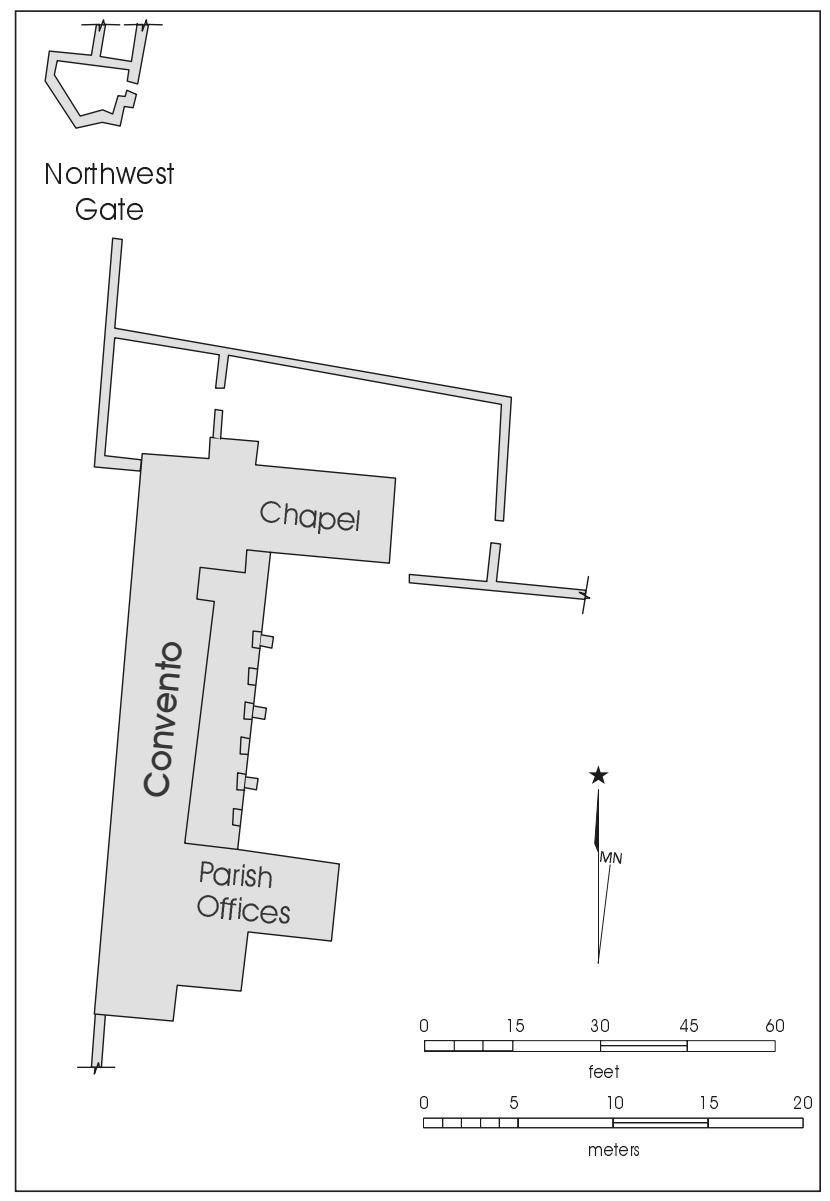

Figure 3. Planview of present-day Convento. 


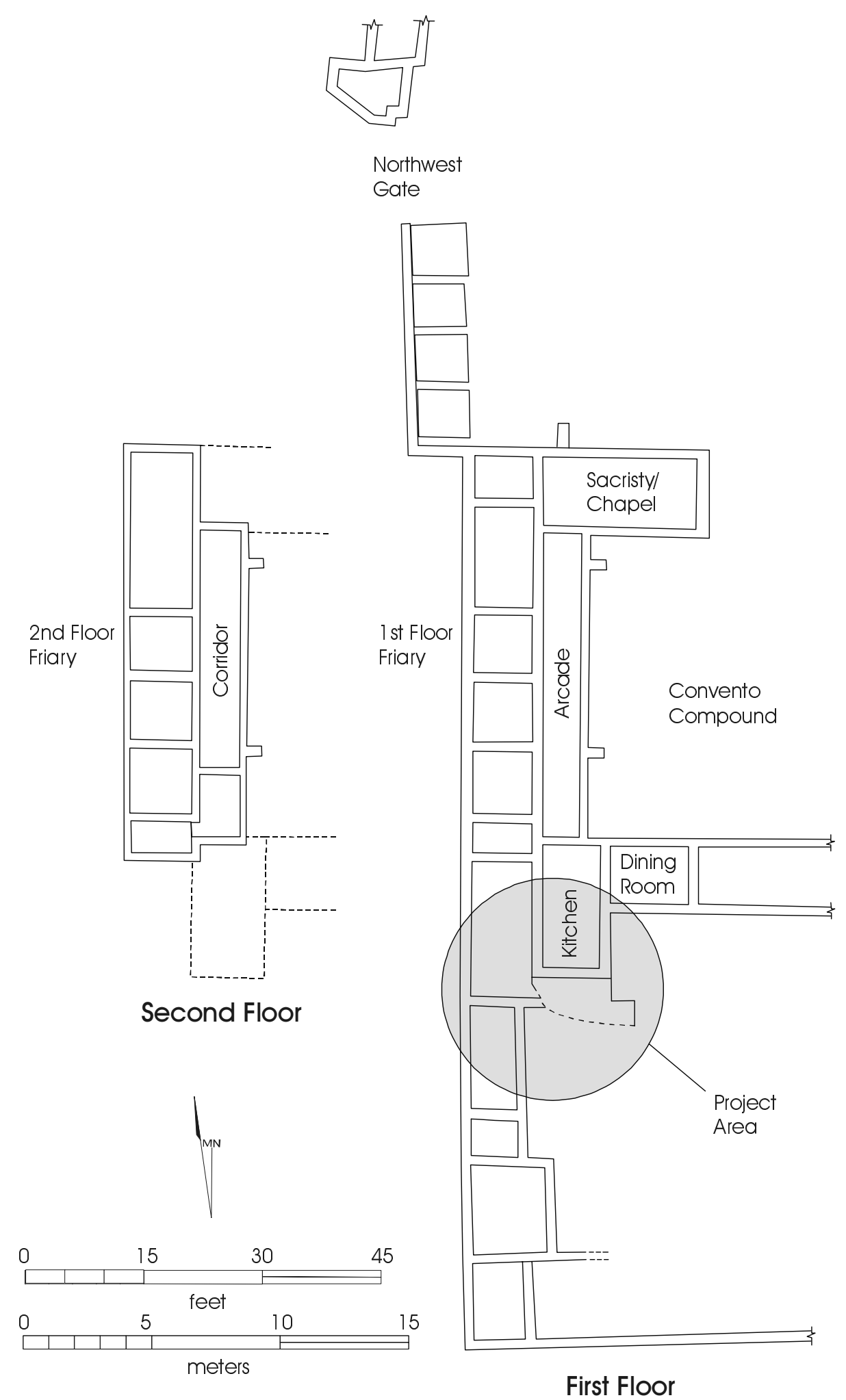

Figure 4. Depiction of Convento at ca. 1772.

Note: Reversal of Kitchen and Dining Room labels below (based on Ivey et al. 1990) 
Partial secularization of the San Antonio missions occurred in 1794, and full secularization in 1824. Over the course of this 30-year period, Mission Espada's population decreased considerably, and ownership of the Convento structures fell into private hands. In 1824 ownership of the kitchen (cocina) and dining room (antecocina) went to Rafael Casillas, and the friary went to Ramos Casillas (Almaráz 1982).

The 1824 inventory associated with the final secularization noted that the kitchen and dining room were in good condition and in use. The two rooms are described as having flat, earthen roofs, although the dining room is described as having an additional roof, probably gabled, which would have created attic space above the original flat roof (Ivey et al. 1990). In contrast, the chapel and friary were in poor condition and, at a minimum, lacked roofs. This same inventory listed most of the mission property in terms of ox-cart loads of stone. The local city council viewed the former missions as sources of reusable construction material, suitable for favored citizens (Almaráz 1982).

Although there were still a few people in-residence at the mission between ca. 1824 and ca. 1867 (Almaráz 1982; Habig 1968), it seems that the mission structures were neglected. Whether true or not, there was enough of the friary and adjoining structures left in 1867 for Father Bouchu to restore and adapt these for use as work and living quarters.

\section{Fr. Bouchu's Legacy}

Father Francis Bouchu (b. 1829 - d. 1907) resided at Mission Espada for approximately 40 years, beginning in 1867 (Habig 1968). According to Habig (1968) and Ivey (1990) he was the person most responsible for the restoration, adaptive reuse, and reconstruction of the Convento's Spanish Colonial fabric. The deed records show that Fr. Bouchu bought the property on which those structures stood from Gregorio Casillas in 1868 (Ivey et al. 1990:313). Besides continuing to purchase mission property, Fr. Bouchu purchased several other properties adjoining the mission (Almaráz 1982). These properties were all purchased with personal funds and under his own name. In his personal ledger, Bouchu has a conceptual drawing of the friary, kitchen, and dining room. Beneath the drawing, on the same page, are ledger entries for 1867 , 1868 and 1869 for the purchase of building materials and for payments to brick makers, carpenters, and masons. From this information it can be assumed that the Convento structures, with the exception of the chapel, underwent various modes of architectural intervention, between 1867 and 1869 .

Fr. Bouchu did not get around to restoring the chapel until ca. 1884, and may have completed the work by ca. 1887 (Ivey et al. 1990). Several photos in the Institute of Texan Cultures collection were helpful in discerning the Convento's metamorphosis. Most of the photos appear to be second and third generation facsimiles and, as a result, their reproduction value for this report would be negligible. The following descriptions are based on a close inspection of the photos, with the use of an $8 x$ loupe.

The earliest photo was taken ca. 1877 and is an east elevation shot of the chapel in ruins, with the bells missing (ITC, 88-322). We note that this is ten years after Fr. Bouchu took up residence at Espada. The next photo of interest was taken some twenty years later (ca. 1887), and shows four men resting on a rock pile, just north of the chapel. The north elevation of the chapel is clearly visible. The photo depicts a low slope, gabled roof; windows that feature louvered shutters; round window pediments; and a batten door in the area of the present-day north transept (ITC, 82-493).

A ca. 1890 photo (ITC, 82-491) shows the Convento to the west-southwest. The west-end of the chapel is visible in this photo, as is the south transept and adjoining sacristy. The transept and sacristy exhibit low sloped tin roofs, and the roof of the sacristy appears to be elevated a bit higher than the roof for the transept. A cluster of three buildings are visible to the south of the chapel. All three are of rubble masonry (mampostería) construction. A two-story structure (friary) with a hip roof is the nearest to the chapel; a second structure with a flat roof extends to the south of the two-story structure (antecocina), and then a third structure (cocina) extends to the east of this second structure. The third structure features a medium sloped wood shingle roof and a half-width porch. The friary and cocina feature chimneys at the gable ends and 
both appear to be off-center. A low stone wall encircles the cocina to the south and east. A picket fence runs north to south along the outer edge of the south transept, towards the cocina.

Another photo of interest was one taken ca. 1900, and depicts Fr. Bouchu in front of his house with a stack of brick tiles in the background (ITC, 83-198). A ca. 1903 photo is a view of the Espada Store (kitchen) to the southwest. The photo includes a note that remarks that the store was "formerly the Chavagneaux's Store operated by Peter Hooge" (ITC, 74-988; photo by Peter Hooge). This would suggest that Fr. Bouchu leased the structure known as the kitchen to Peter Hooge and to Elizabeth and/or Margaret Chavagneaux; persons he had named in his "will" (Escobedo 1984).

\section{Post-1907}

After the death of Father Bouchu in 1907, the mission was placed under the care of the Claretians, and the chapel fell into disuse from 1909 to 1915 . The Claretians apparently discontinued services at the Espada chapel and transferred these over to Mission San Juan. Beginning around 1916, the diocese handed over responsibility of the mission to Fr. William Hume. With diocesan support, Fr. Hume was able to carry out some reconstruction of the Espada chapel. Father Hume replaced the roof, added parapet walls above the roof line, a ceiling, brick flooring, doors, and windows (Thurber et al. 1993).

Between 1922 and 1931, the Redemptorist Fathers cleaned up the exterior of the Convento, refitted the rooms at the south-end of the complex as a residence and schoolhouse. During this same period, the doors and windows of the chapel were again replaced.

After this period, additional work to the structures located at Mission Espada was not undertaken for another twenty years. However, during the early- and mid-1930s, Harvey P. Smith managed to develop a series of measured and restoration drawings (AAAPL). And, in 1936, the Historic American Buildings Survey (HABS) photo-documented all of the San Antonio missions (Thurber et al. 1993).
The spatial configuration which was depicted in Smith's ca. 1957 reconstruction (i.e., the present-day appearance, see Figure 3), is practically the same as Ivey's conceptualization (see Figure 4). However, Harvey's reconstruction did not include a second story for the friary and Ivey's drawings did not include the room at the southwest corner of the Convento. The Priest quarters (see Figure 2) was conceived by Smith and was said to be constructed on remnants of Spanish Colonial foundation (ASA, Bishop Leven's letter dated 31 October 1956).

\section{Notes on Structural Interventions}

As reported here, the location of the dining room and kitchen is the reverse of Ivey's conceptual plan map (refer to Figure 4 and Figure 5b). Instead, we elected to follow the configuration suggested by Almaráz (1982). This is an important point, since the location of these two buildings will relate to later discussions and interpretation of the artifactual evidence.

Iveys' configuration of the Convento (see Figure 4) is based on a 1772 itemized inventory. In recounting the inventory, Ivey moves south from the chapel, describing a series of cells or workrooms which butt up against the two-story friary. He describes first -a kitchen adjacent to and east of the friary, which is followed by an antecocina or dining room. In his land tenure study, which is also based on the 1772 inventory, Almaráz (1982) also moves south from the chapel, describing the various offices and cells and lists the dining room and then the kitchen (as depicted in Figure 5b). Almaráz also provides the dimensions for both structures. The dining room is said to be 5 varas wide by 7.5 varas long ( $13.9 \mathrm{ft}$ x $20.8 \mathrm{ft}$.), and the kitchen 5 varas wide by 10.75 varas long (13.9 ft. x $29.8 \mathrm{ft}$.). The conversion of varas to feet is based on the standard of $331 / 3$ inches to a vara.

Although we concur with Almaráz (1982) on the location of these structures, we believe that the dimensions were mislabeled. In the first place, it seems illogical that the kitchen would be larger than the dining room. Also, after converting and comparing the room dimensions, it seems that the sizes quoted by Almaráz are interior dimensions. Using the recent 


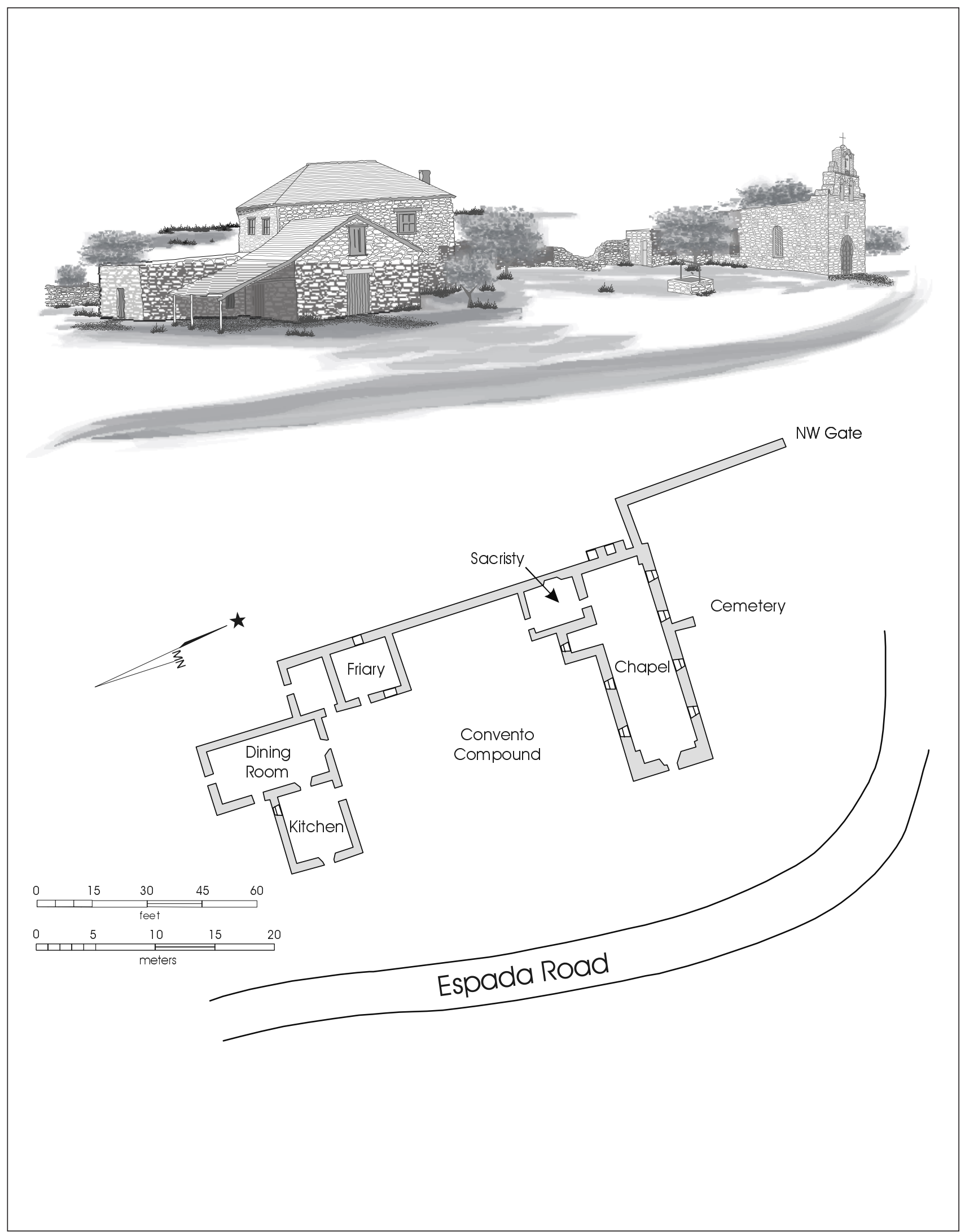

Figure 5a-b. Convento at ca. 1890 - view to the northwest.

(Based on ITC 82-491A and Corner 1890) 
architectural drawings of Ford, Powell, and Carson, Inc. the interior measurements of the structure we call the dining room are $14 \mathrm{ft}$. by $30.5 \mathrm{ft}$., and $14 \mathrm{ft}$. by $21.5 \mathrm{ft}$. for the kitchen. These measurements indicate that the width for both rooms is off by one-tenth of a foot and the length by seven-tenths of a foot. These discrepancies may be related to conversions and/or rounding errors.

The following figures depict the Convento at ca. 1890 (see Figures 5a and 5b). This marks an important period in Fr. Bouchu's 40-year residency, since we believe that most of the work he had accomplished had been completed by this date.

Figure 5a is a computer enhanced image of a ca. 1890 photograph believed to have been taken by Fr. Bouchu (ITC, 82-491A). The quality of this photo prevented its reproduction here. The enhanced image shows the kitchen (foreground) as a pitched roof structure with a loft above, and a half-width porch along its south elevation. The friary is the two-story, hip roof structure in the background, and the flat-roofed dining room is situated between the friary and kitchen. The details for the well and chapel were derived from two ca. 1890 photos using an 8x loupe (ITC 75-1158 and ITC $75-1157)$. Figure $5 b$ is taken from Corner's (1890) plan map of Mission Espada, which he sketched while on a visit to the mission, and shows good conformity to Figure 5a. Based on the Historic American Building Survey photos of ca. 1936, these structures were extant at this late date (CAT, HABS Tex-3-20, 53674).

\section{Summary of Impacts}

The accumulated data suggest an almost uninterrupted occupation of the Convento that spans 270 years:

\begin{tabular}{|c|c|c|}
\hline Franciscans & $1731-1794$ & (64 yrs.) \\
\hline Casillas Family & $1794-1868$ & (74 yrs.) \\
\hline Fr. Bouchu & $1868-1907$ & (39 yrs.) \\
\hline \multicolumn{3}{|c|}{ Peter Hooge, Executor of the Estate } \\
\hline & $\begin{array}{l}1907-1915 \\
\text { of San Ant }\end{array}$ & ( 9 yrs.) \\
\hline
\end{tabular}

This means that the morphological evolution of the mission has been influenced by no less than five culturally distinct occupants (e.g., Spaniard, Native American, Tejano, French, and Anglo). As a result, the historic fabric of the Convento complex has been mostly replaced by successive structural adaptations. The most notable alterations were caused by Fr. Bouchu's reconstruction and adaptive reuse efforts of ca. 1867-90, and then by the extensive restoration efforts of Harvey P. Smith and the Archdiocese at ca. 1956, however, the basic layout of the Convento has persisted throughout the whole of this evolution. 


\section{Previous Research}

To date a total of 10 archaeological studies of Mission San Francisco de la Espada have been undertaken, but all have been limited and isolated in both scope and areal extent. The following summarizes the major findings of each study. Figure 6 indicates the approximate location of each of the previous eight investigations and the two reported here.

1. The Fox and Hester (1976) investigation of the bastion was the earliest archaeological study of this mission. In May 1976, Anne Fox of CARUTSA excavated three $1-\mathrm{m}$ by $1-\mathrm{m}$ units along the exterior and interior walls of the bastion. This was a limited study designed to determine the mode of construction of the wall footings, which would aid in the planned stabilization of the bastion (Fox and Hester 1976). For this purpose, two of the units were located along the exterior east and west wall of the bastion, and the third was located along the interior south wall. The findings of this investigation noted that the wall footing was constructed of " $50 \mathrm{~cm}$ of rubble set in soil, packed into a trench the same thickness as the wall." The wall was described as being "constructed of roughly shaped local stone, set in a sand and lime mortar" (Fox and Hester 1976:22). Although Fox was unsuccessful in establishing a date of construction for this feature, there are references made in relation to this bastion from as early as 1772 (Fox and Hester 1976:4).

2. In March 1977, Killen and Scurlock (1976), working for the Texas Historical Commission, excavated four kilns located immediately north-northeast of the compound. Only the interior of the kilns were excavated, and the recovered artifacts were of Colonial and post-Colonial origin. The features are considered to be Spanish Colonial in nature and interpreted as being lime kilns. Due to time constraints, only one of the four kilns was excavated to its final depth, and the adjacent areas were not investigated. These features were backfilled and then capped with corrugated metal sheets for future consideration.

3. In 1981, Anne Fox of CAR-UTSA conducted archaeological investigations of two areas (Area A and Area B). A total of three units were excavated immediately north of the chapel (Area A, Units 1, $2 \& 5)$. Testing of Area A was designed to identify and document cultural features and/or deposits, in order to make way for the existing, caliche-paved, parking area. The second area tested (Area B, Units 3 \& 4) was designed to document an early-twentieth century building, referred to as either the Oaks House or the Old Convent. This area is located at the opposite, exterior east wall of the compound. Fox concluded that the proposed parking area (Area A) would not impact the Mission's cultural resources, but did suggest future improvements in this area be limited to raising the present grade of the caliche gravel, rather than cutting into it. Fox located a minimal amount of architectural evidence of the Old Convent and proposed that future development of Area B would not impact the Mission's cultural resources.

4. In 1983, Anne Fox of CAR-UTSA conducted archaeological monitoring of coring activities and a limited test excavation. A total of five core drills were located within the immediate vicinity of the Convento, and a sixth was placed at the exterior northwest corner of the mission compound. The core drilling and limited test excavation was designed to secure subsurface information in connection with wall stabilization efforts. The results of the cores noted dark loamy and clayey soils to about 3 meters below surface, and then caliche to about 6.1 meters, at which point water was reached. The $3-\mathrm{ft}$. by 5 -ft. $(.9 \times 1.5 \mathrm{~m})$ test trench was located along the west perimeter wall of the 


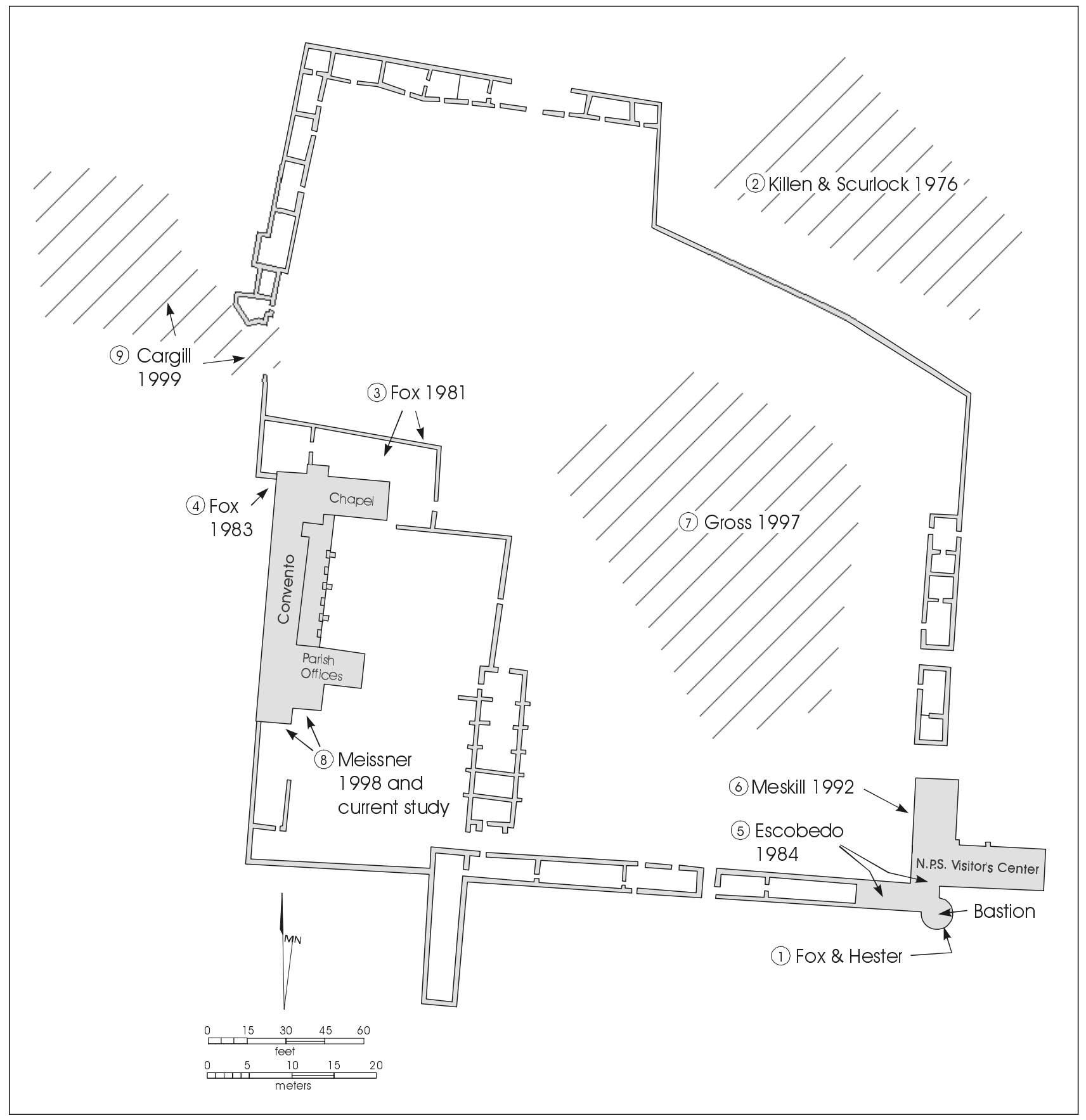

Figure 6. Previous Archaeological Investigations.

compound, just south of the chapel. The excavation located the extent of the wall at about 1.2 meters below surface. The wall footer extended between 1.2 and 1.6 meters below surface. The results of the excavation did note that various stages of wall collapse and rebuilding had occurred in this area.
5. Prior to initiating a structural stabilization project, the National Park Service excavated two rooms to the north and west of the bastion (Escobedo 1984). Escobedo's investigation included extensive archival research and an abstract of the property. These excavations were designed to define the nature of the rooms and to identify any 
Colonial features. One trench and six test pits were excavated in the interior of the North Room (Casanova Room), and one test pit was excavated inside the West Room (Diaz Room). The most significant find was the location of a flagstone floor in the West Room, which was presumed to be Colonial period in origin. Escobedo concluded that the rooms were probably constructed ca. 1785 and that, contrary to Fox and Hester (1976:4), the bastion was constructed ca. mid-1820s. Escobedo also suggested that the Mission was constructed in phases and that, the Southeast section represented the last construction phase.

6. In October 1990, staff of UTSA-CAR (Meskill 1992) excavated three units within the southeast corner of the compound. One of these units was located within the plaza away from any structures, while the other two were placed along the walls of the structures. Testing in the structure area was designed to examine foundations and determine the extent of Spanish Colonial and Mexican period cultural fill. A twentieth century concrete foundation was exposed beneath the east wall at Unit 1, and a Spanish Colonial stone-rubble foundation was located against the south wall at Unit 2. Testing within the plaza (Unit 3) resulted in the location of a loose stone alignment, which was attributed to a previously recorded low-lying wall. The results of these excavations indicate that a portion of the original foundation, along the east wall, was modified at ca. 1930. The wall footer along the south wall extends approximately 50 $\mathrm{cm}$ below the actual depth of the wall construction. The wall alignment exposed within Unit 3, with a north to south orientation, was located at approximately $10 \mathrm{~cm}$ below surface. Excavation of Unit 3 ceased at $45 \mathrm{~cm}$ below surface and was determined to be culturally sterile at that point. Meskill did caution against any below-grade disturbances being conducted in this area of the Mission compound.

7. In advance of a proposed movie set construction, within the area known as the New Plaza, CARUTSA (Gross 1997) executed a series of shovel tests. A total of 25 shovel tests were placed at 50 $\mathrm{ft}$. intervals within a $200 \mathrm{ft}$. by $300 \mathrm{ft}$. area. An additional shovel test was placed five feet west of ST A4 in order to investigate a possible stone alignment. Based on the recovered cultural material, the results of this testing suggest an earlier occupation or use of the north-end of the plaza. The occurrence of Colonial artifacts and bone fragments at the north-end was much greater than that at the south-end. As a result, Gross suggested that the north-end of the New Plaza may contain intact Spanish Colonial deposits, and that this area should be avoided until after the proposed 6 to 12 inches of fill was added.

8. In April 1998, CAR-UTSA (Meissner 1998a) monitored the excavation of a 10 inch wide by 18 inch deep hand-excavated trench along the southend of the Priest quarters and parish office. Excavation of this trench was for the purpose of installing a below-grade electrical conduit. Monitoring of this activity resulted in the collection of a small sample of diagnostic artifacts and the recording of noted cultural features. As a result of locating a wall foundation, as well as large fragments of bone and ceramics, Meissner cautioned against any future excavation in this area. The wall foundation was located about eight feet east of the reconstructed north to south perimeter wall, and a high density of Spanish Colonial ceramics were also located in this same general area.

9. As a result of planned drainage improvements and construction of a hike and bike trail, a series of monitoring and testing activities were carried out between September 1998 and March 1999 (Cargill 1999). The work accomplished by the staff of CAR-UTSA included a pedestrian survey, backhoe trenching and testing of areas to be impacted, monitoring of work-in-progress, and the execution of numerous test units, as well as mitigation of an early-twentieth century pottery kiln. The affected areas included the outer periphery of the Mission, to the south and west, as well as testing along the Mission's northwest gate. 


\section{Scope of Work}

Testing along the south-end of the Convento's south and east walls was conducted in 1998 and 1999 in order to mitigate the effects of a wall stabilization project. These projects were related to work that was scheduled to be carried out by the architectural firm of Ford, Powell, and Carson, Inc.

The proposed structural interventions consisted of the installation of foundation piers and beams along the length of south-end walls of the Priest quarters.

The objective of the mitigation was to investigate the construction of these walls, materials used, and mode of construction. This investigation would also attempt to determine when these walls were constructed; that is, whether they were part of the original mission complex or were later additions. This investigation was also designed to determine if intact Spanish Colonial to mid-nineteenth century deposits existed along the south wall. Based on Meissner's (1998a) monitoring activity and preliminary analysis of the November 1998 excavation data (reported here), we were aware that intact Spanish Colonial deposits existed along the far west-end of the south wall of the Priest quarters. This same data indicated that portions of these deposits had been severely impacted by twentieth century construction activities. Also, the excavations were designed to determine whether there were any buried foundations or other structures which might predate, or postdate, the Priest quarters (Meissner 1998a). In addition to the excavations, the study was augmented through archival research that focused on the structural history of the Convento. A preliminary review of historic photographs and records suggested that the project area had been considerably impacted by successive building activities. As a result, the expected Spanish Colonial evidence may have been destroyed by building activities.

\section{Excavations}

Almost the entire length along the south-end Convento walls were impacted by two distinct projects reported here. The area impacted was about one meter deep by one meter wide, and 25.2 meters long. The first investigation was completed in November 1998 and was carried out in advance of a project to install new electrical lines. Additional excavations were carried out during the months of July and August 1999. This second investigation was designed to mitigate the impact of trenching activity related to the stabilization of the wall foundations.

The November 1998 excavations impacted a 1 x 2 meter area along the southwest corner of the Convento. This investigation was conducted in advance of a Ford, Powell, and Carson, Inc., project designed to install new electrical lines. The extent of the $1 \times 2$ meter area was precluded by the south elevation wall of the Priest quarters (north) and the compound's west perimeter. The area was then divided into two distinct units, designated Unit A and Unit B (refer to Figure 2). Units A and $B$ were excavated to $85 \mathrm{~cm}$ below surface. With the exception of the first level (excavated $0-30 \mathrm{~cm}$ ), the remaining levels were excavated in arbitrary increments of $10 \mathrm{~cm}$.

Additional excavations were carried out during the months of July and August 1999. The data recovery program, based on the 1998 investigation, was designed to mitigate the impact of trenching activity related to the stabilization of the wall foundations on the south-end of the Convento. The work was divided into two phases; a testing phase and a mitigation phase. Progression into the second phase was contingent upon the preliminary findings of the testing phase.

The testing phase of the project consisted of the excavation of six 1-x-1 meter units, designated Units 1-6, 
located adjacent to walls 2, 3, 4 and 5 (see Figure 2). The purpose of these units was to determine if there were intact Colonial features that might be adversely impacted by the proposed foundation work, and also was to be investigated in advance of the Ford, Powell, and Carson, Inc., project. Completion of the testing phase determined that there were significant amounts of intact Colonial features to warrant the second phase of mitigation.

The second phase of the investigation consisted of the excavation of eight $1-x-1$ meter units, one $1-x-1.5$ meter unit and one 1.3-x-1.4 meter unit. These units were designated Units 7-16 and located adjacent to walls 1, 2, 3, 4 and 5. All units from both phases of the project were excavated to sterile soils, or a minimum depth of $80 \mathrm{~cm}$ below surface. Excavations proceeded in arbitrary levels of $10 \mathrm{~cm}$, except where cultural features dictated otherwise.

The discovery of a wall foundation along Wall 3 (designated Feature $\mathrm{A}$ ) required additional mitigation (see Figure 7). The stone feature was plan mapped and profiled as it was revealed in the excavation units. After the feature was completely revealed it was photographed both at ground level and from a bird's-eye perspective at approximately twelve feet above ground surface. Because the feature lay directly in the path of

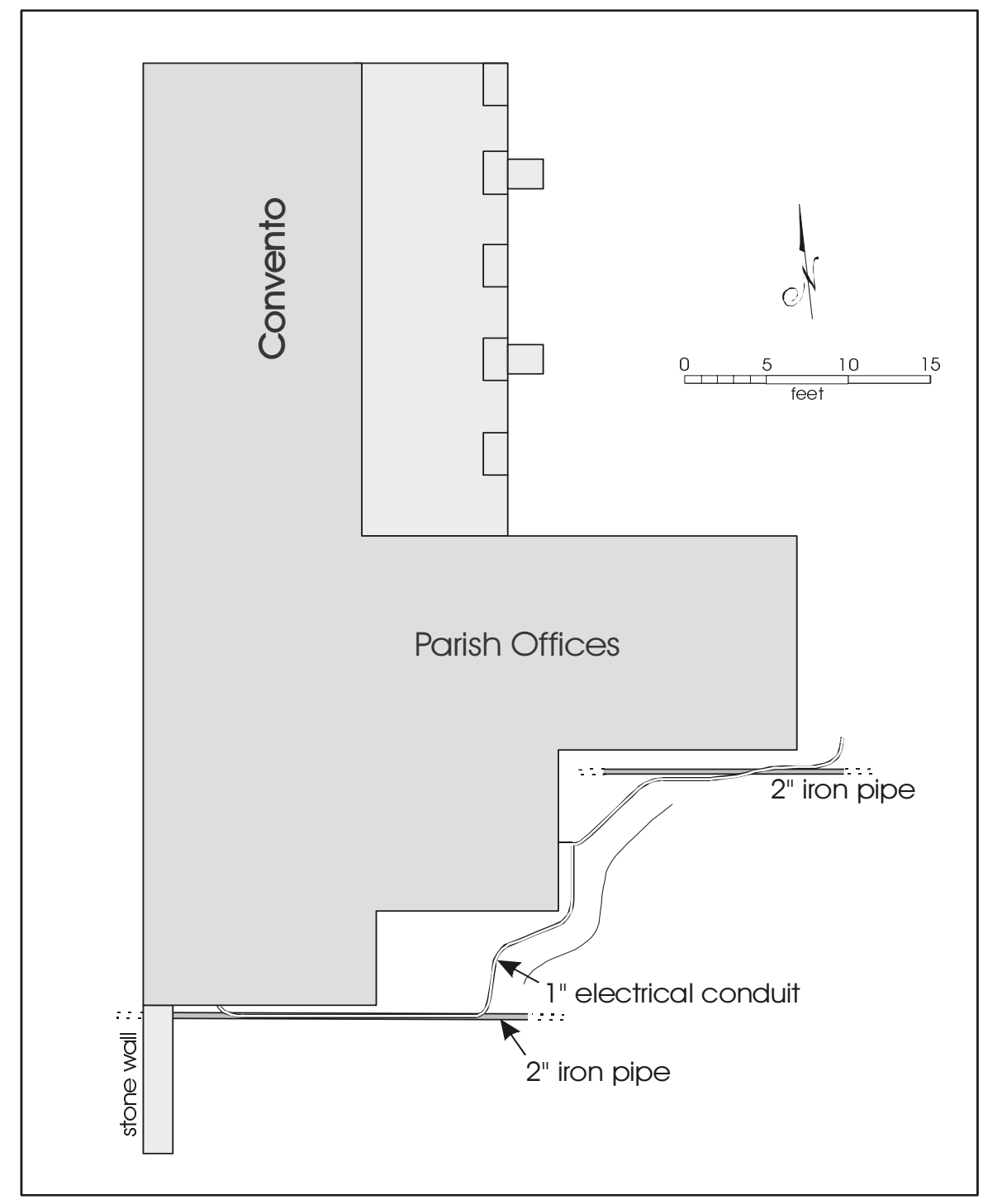

Figure 7. Project Area Plan Map. 
the proposed foundation work it was decided that the wall would be removed. The stones from each course of the foundation were carefully labeled and removed, with each subsequent course being plan mapped. The stones were placed on a pallet and possession was relinquished to the National Park Service.

Another stone alignment (designated Feature B) was discovered along Wall 2. This feature was also plan mapped and profiled after being fully exposed. It was photographed at ground level and also from a bird'seye perspective (see Figure 7). Because this feature also lay in the path of the proposed foundation work it was decided that it too would be removed. This feature was plan mapped and removed in courses from the top down to sterile soil. The stones were labeled as they were removed and possession of these stones from the alignment of Feature B were relinquished to the National Park Service.

While excavations conducted along Walls 1, 2, and 3 were contiguous, excavations along Walls 4 and 5 were staggered (refer to Figure 2). The general contractor eventually removed the soils from the unexcavated areas, under the supervision of a staff archaeologist from CAR-UTSA. The monitoring work performed in these areas was designed to ensure that any unknown cultural features would not be adversely impacted by the removal of soil for the repair of the foundation.

In both the 1998 and 1999 projects soils were screened through 3-inch wire mesh and artifacts collected. The recovered cultural material was transported to the CAR-UTSA laboratory for processing, analysis, and curation. Included in this report is a detailed analysis of Native American and Colonial ceramics and other artifacts from this study, as well as the analysis regarding the faunal and lithic material recovered. All structural details were recorded and mapped in an effort to determine the construction history of the architectural features.

The excavations were complemented with archival research in order to determine the construction sequence and structural history of this section of the Convento. The available archival records were reviewed to determine when rooms were constructed and by whom. This research included a study of all available photographs of the mission at different periods in its history, as well as descriptions recorded by various visitors during Colonial and later times. The collections at the Catholic Archives of Texas, the Archdiocese of San Antonio, and the photograph collection at the Institute of Texan Cultures were consulted. The written sources found to be most noteworthy were the Land Tenure Study of the San Antonio Missions (Almaráz 1982), and Of Various Magnificence, The Architectural History of the San Antonio Missions (Ivey et al. 1990; Thurber et al. 1993). 


\section{Results of the Excavations}

Eighteen units along Walls 1-5 were archaeologically excavated and the remaining area was monitored during construction. The excavated volume was one meter wide, one meter deep, and 25.2 meters long. The results of the excavations and monitoring are outlined below. Particular attention is paid to Features and the presence of intact Colonial deposits. These discussions are presented in order, in accordance with their structural relationship from Walls 1-5 as follows: Walls 12 ca. 1956 Priest quarters; Walls 3-4 ca. 1756 dining room; and Wall 5 ca. 1756 kitchen.

Prior to beginning excavations, the datum for Units A and $\mathrm{B}$ was set at $20 \mathrm{~cm}$ above surface, while the datum for Units 1 through 16 was set at $10 \mathrm{~cm}$ above surface. Given that the surface along the south-end of the complex is gently undulating, depth measurements were easily adjusted to below surface. Throughout the report the unit levels have been changed to reflect "below surface" (bs) rather than below datum (bd) depth. Example, Units A and B, Level 1 (0-30 cm bd) is now Level $1(0-10 \mathrm{~cm} \mathrm{bs})$, and Units 1-16, Level 1 $(0-20 \mathrm{~cm} \mathrm{bd})$ is now Level $1(0-10 \mathrm{~cm} \mathrm{bs})$. In this way the depth controls of the two projects are comparable.

\section{Excavations - Walls 1 and 2, ca. 1956 Rectory}

Walls 1 and 2 form the south-end of the ca. 1956 rectory. A total of 10 units were excavated along this 9.3$\mathrm{m}$ length of walls. Two of the 10 units were excavated in 1998, while the other eight were excavated in 1999. Discussion of these excavations follows the units as they occur along Wall 1 from west to east (Units A, B, $16,13,9,8$, and 7), and Wall 2 from south to north (Units 15, 10, and 1).

A $1 \times 2 \mathrm{~m}$ area was located along the southwest corner of the Convento, and the area was then divided into two distinct units, designated Unit A and Unit B (see Figure 2). The excavations located two subsur- face disturbances: a two-inch PVC, electrical conduit was located at about $35 \mathrm{~cm}$ below surface and across the west end of the $1 \times 2 \mathrm{~m}$ area. The approximate depth and path of this conduit had been monitored and recorded by Meissner (1998a:5, see Figure 5). In addition, a two-inch galvanized gas line was located at $50 \mathrm{~cm}$ below surface. This line was oriented eastwest along the entire length of the excavated area. The galvanized pipe was located towards the bottom of a trench that extended along the entire length of Wall 1. The pipe trench measured approximately $45 \mathrm{~cm}$ wide and extended to $65 \mathrm{~cm}$ below surface (see Figure 7).

A portion of what appeared to be Spanish Colonial foundation was exposed in the west wall of Unit A, between 54 and $61 \mathrm{~cm}$ below surface. This wall foundation relates to the west perimeter wall, and not the ca. 1956 rectory. This section of wall footing was believed to be undisturbed, since it was found in association with a solid caliche-packed surface. The wall footing continued to a depth of approximately $83-\mathrm{cm}$ below surface. A majolica blue-on-white ceramic dish rim sherd dating to the Colonial period was discovered in the caliche matrix at $53 \mathrm{~cm}$ below surface. Excavation of this caliche surface also uncovered a posthole that was located approximately $12 \mathrm{~cm}$ south of the north wall profile of Unit A, and about $73 \mathrm{~cm}$ from the west compound wall. The posthole measured $17.5 \mathrm{~cm}$ in diameter and its depth was between 65 and $85 \mathrm{~cm}$ below surface. The posthole fill was composed of a mixture of ash, charcoal, and caliche.

Exposure of the ca. 1956 rectory wall foundations was of interest, since this room was supposedly constructed on remnants of a Spanish Colonial foundation. As a results of the Unit A excavations, a portion of Spanish Colonial wall footing was exposed along Wall 1 (see Figure 8). The figure represents a typical wall footer that begins at ca. $5-\mathrm{cm}$ bs and extends to ca. $70 \mathrm{~cm}$ bs. This foundation sits on ca. $10 \mathrm{~cm}$ layer of Houston 


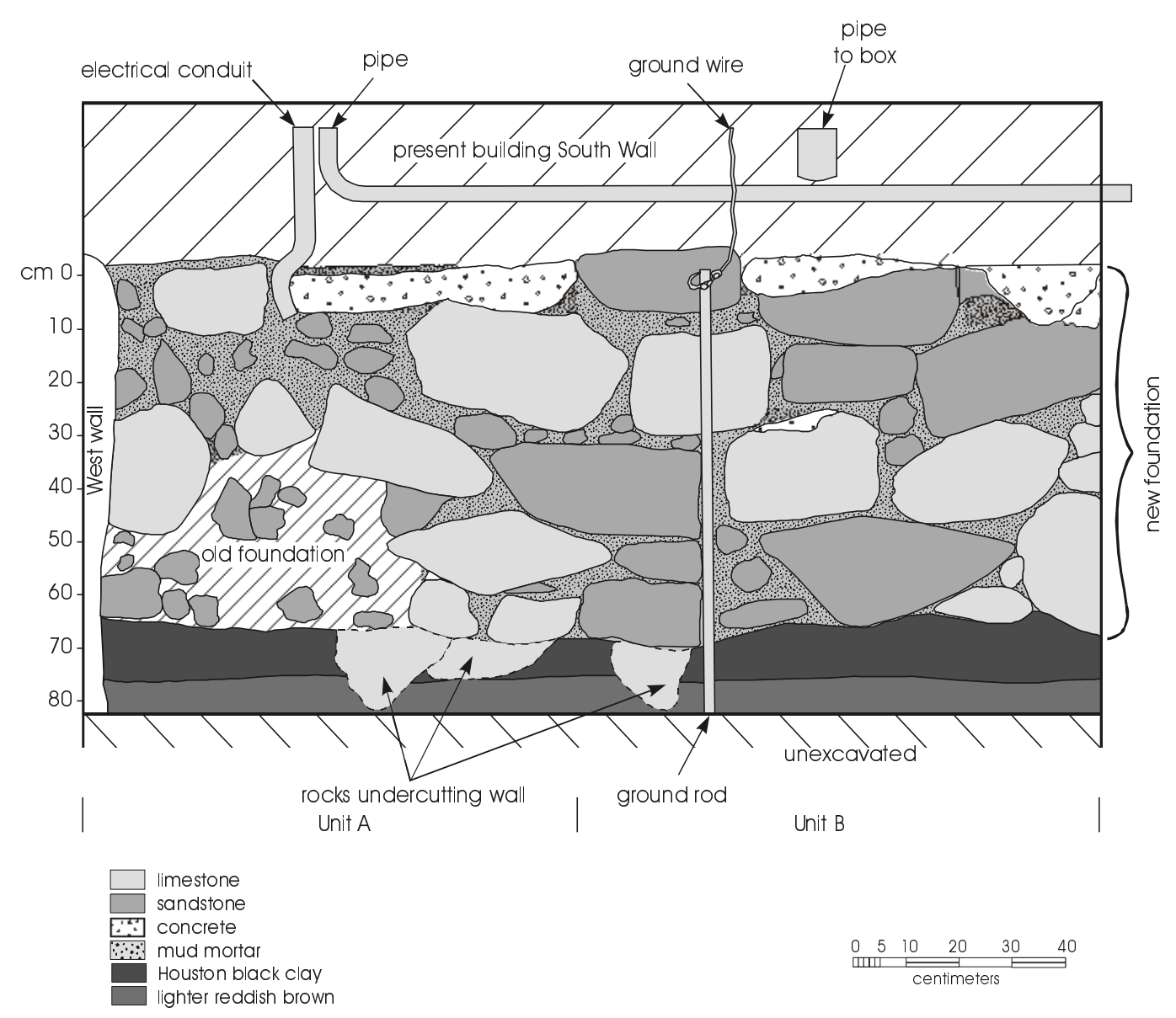

Figure 8. Wall 1 Footer, North Profile Units A and B.

black clay, followed by a light, reddish brown clay. A few limestone rocks undercut the wall and continued to about $82 \mathrm{~cm}$ below surface. The original footing was located at a depth beginning approximately 32 $\mathrm{cm}$ below surface and extended to about $70 \mathrm{~cm}$ below surface. This portion of Spanish Colonial wall foundation was distinct from the reconstructed portions, since it was made up of yellowish mortar mixed with small unevenly shaped rocks. The reconstructed wall foundations were made up of a mixture of cut and uncut limestone and sandstone, mud mortar, as well as cement. Figure 9 relates to the additional excavations along Wall 1 and illustrates the exposed wall footer. The extent and appearance of the wall and footer, is typical for Walls 1-5.

The most important aspect of the illustration is Feature $\mathrm{B}$, and a discussion of this feature follows.
Wall rubble was found in the south wall of Units A and $\mathrm{B}$, and was also picked up on the south wall of Units 16 and 13 . Figure 10 serves to illustrate the disturbance encountered in the excavated units. The wall fall, or construction debris, was located between 15 and $40 \mathrm{~cm}$ below surface, and was oriented in an eastwest direction. In 1998, Meissner mentioned this anomaly in her monitoring notes, and speculated that it might be a north to south wall alignment

The 1999 excavations of Units 16, 13, 9, 8, and 7, continued noting the presence of disturbed deposits along Wall 1 . The unit levels were fairly consistent: Levels 1-3 (0-30 cm bs) noted disturbed loamy soils with mixed deposits; Levels 4-5 (30-50 cm bs) noted disturbed loamy soils with few artifacts; Level 6 (50$60 \mathrm{~cm} \mathrm{bs}$ ) located a sandy loam with either few or no artifacts; and Levels 7-9 (60-90 cm bs) noted a layer of Houston black clay with either few or no artifacts. 


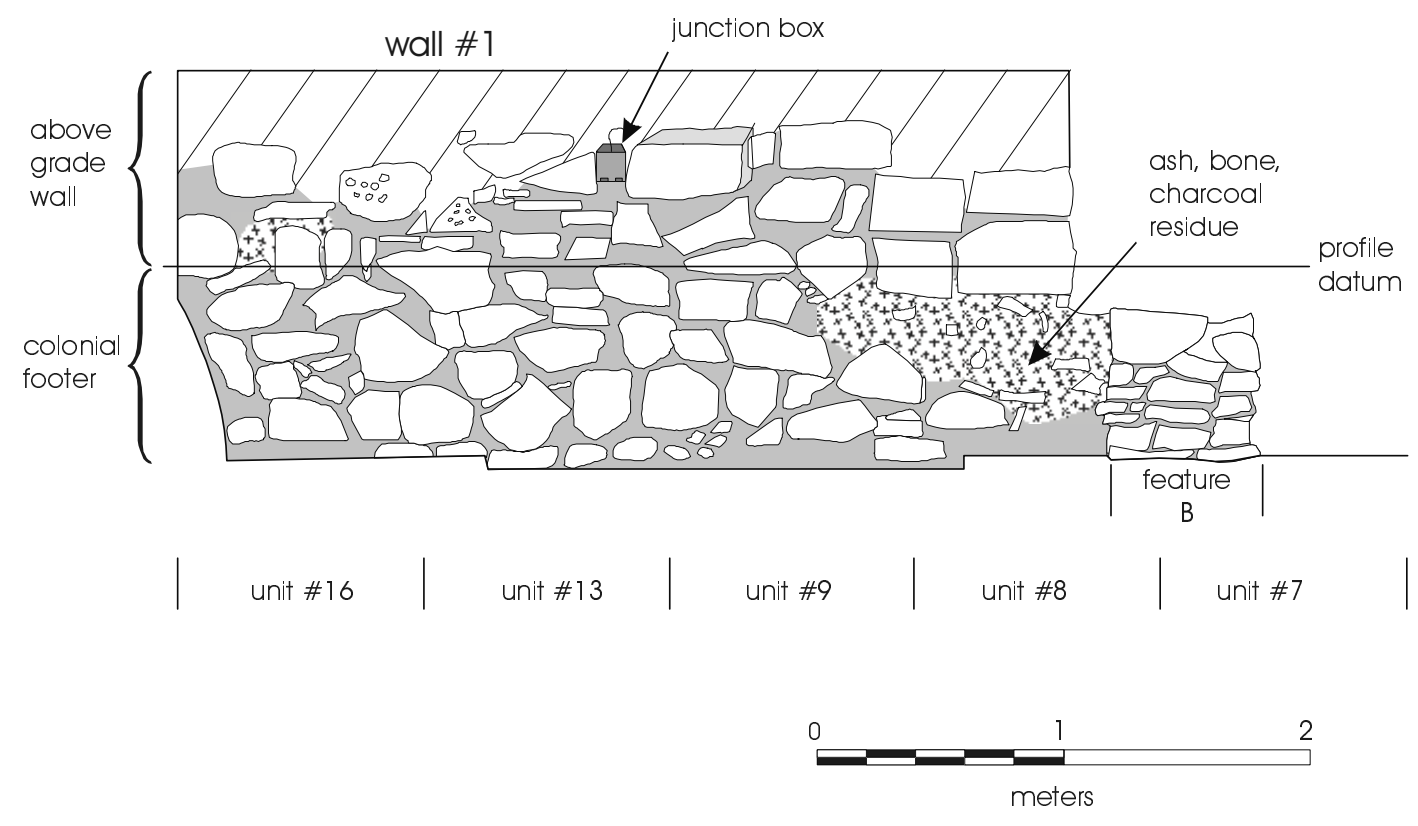

Figure 9. Wall 1 Footer, North Profile Units 16, 13, 9, 8, and 7.

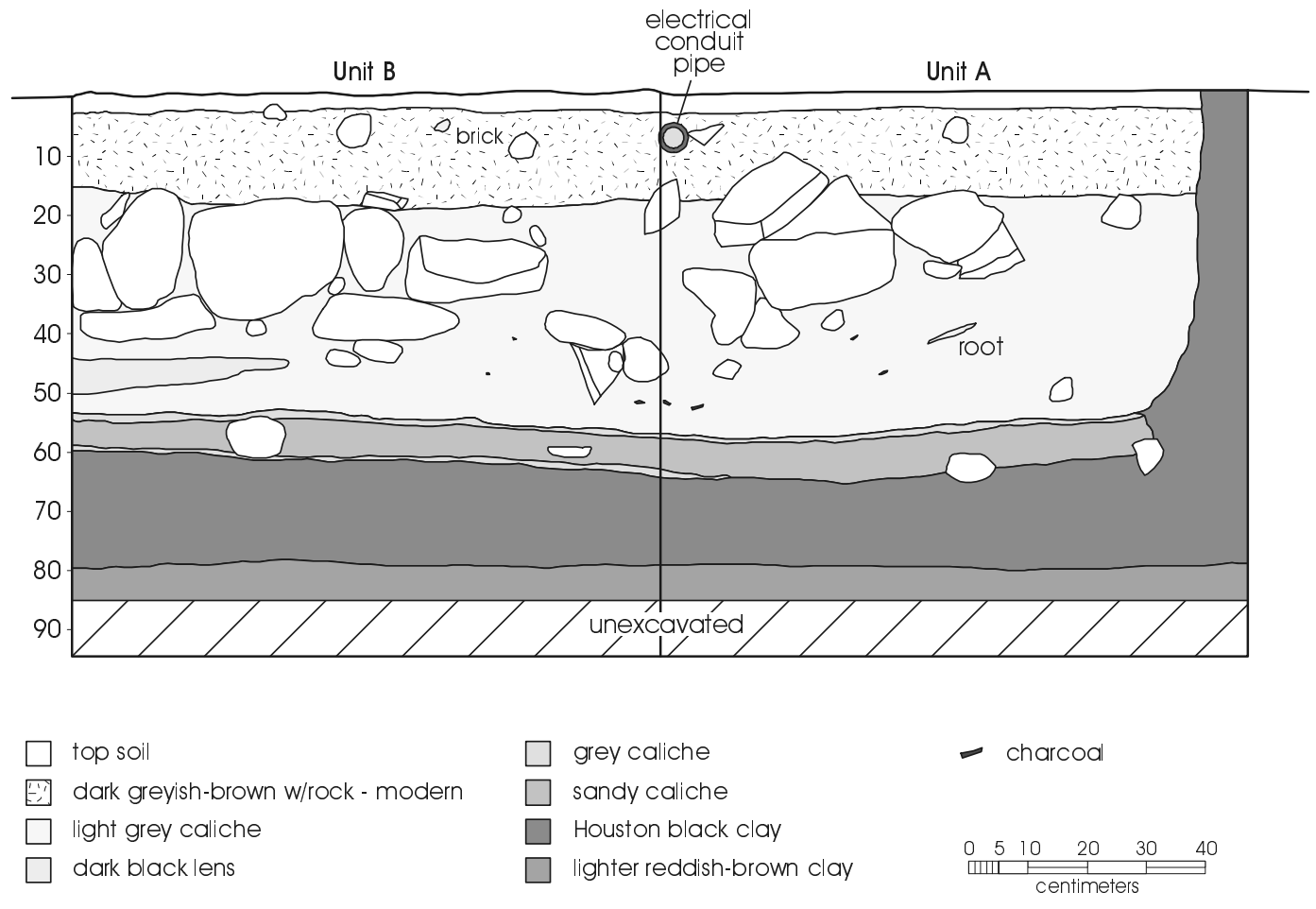

Figure 10. Units $A$ and $B$-South Profile. 
Excavation of Units 15, 10, and 1, along Wall 2, also noted this same mixed stratigraphy although only onethird of the units to the east were archaeologically excavated. Two-thirds of the area excavated was impeded by a north-south rock alignment, encountered at approximately $20 \mathrm{~cm}$ bs, and designated Feature B. This ca. $80 \mathrm{~cm}$ wide feature extended to approximately $80 \mathrm{~cm} \mathrm{bs}$, and is either a Spanish Colonial wall foundation or buttress.

The excavations did not encounter any distinguishable layers or deposits, and the cultural material ranged from modern to Spanish Colonial. Loamy soils were typically encountered in the upper $50-60 \mathrm{~cm}$ of fill, as were traces of ash and charcoal. Ash and charcoal residue was especially evident along Wall 1, Unit 8 (10$60 \mathrm{~cm} \mathrm{bs}$ ) (see Figure 9), but none of the associated artifacts were charred. An artifact of note, was a gunflint that was recovered from Unit 1, Level 2 (10$20 \mathrm{~cm} \mathrm{bs}$ ). The artifact density dropped considerably between 50 and $60 \mathrm{~cm}$ below surface. Only five percent of the total $(n=4307)$ was recovered from between 60 and $90 \mathrm{~cm}$ bs, and was almost non-existent in the dark clay loam, between 60 and $80 \mathrm{~cm}$ below surface. The highest number of artifacts were construction-related items ( $\mathrm{n}=2340$ or $54 \%$ ), such as nails, masonry debris, and window glass. The next highest category was kitchen/household ( $\mathrm{n}=1403$ or $33 \%$ ), which included a high number of glass shards $(\mathrm{n}=812)$. Of the total artifacts recovered from along Walls 1 and 2, only seven percent $(n=313)$ were ceramics.

\section{Excavations along Walls 3 and 4, ca. 1756 Dining Room}

A total of seven units were excavated along Walls 3 and 4, including Unit 1. Only $7.2 \mathrm{~m}$ of the $9.4 \mathrm{~m}$ length along Walls 3 and 4 was archaeologically excavated. Discussion of these excavations follows the units as they occur along Wall 3 from west to east (Units 1, $11,14,2$, and 12) and Wall 4 from south to north (Units 3 and 4).

A rock-constructed wall feature was encountered in Unit 1 at a depth of $17 \mathrm{~cm}$ below surface, and was designated Feature A. Excavation of Unit 2 encountered the east-west feature at a depth of about $20 \mathrm{~cm}$ bs, and also extending into Units 11 and 14. Although the encountered depth and width of Feature A varied between units, this feature was located at approximately $10 \mathrm{~cm}$ bs and extended to $68 \mathrm{~cm}$ bs, and was $80 \mathrm{~cm}$ wide where intact. The upper-most layer of Feature A consisted of eight large stones (ca. 25-40 $\mathrm{cm}$ wide and 10-15 cm thick); most of these stones exhibited at least one perfectly flat side. Excavation of Units 7, 8, 10, and 15 (discussed above) located Feature B and noted its association with Feature A. Feature B, another wall feature, was located at approximately $20 \mathrm{~cm}$ bs and extended to $85 \mathrm{~cm} \mathrm{bs}$, and was $60 \mathrm{~cm}$ wide. The bird's-eye view shown in Figure 11 illustrates the relationship between Feature A and Feature B.

A 9-cm layer of fist-size river cobble was revealed in Unit 12 between 38 and $47 \mathrm{~cm}$ below surface. These cobbles appeared to be running in a north-south alignment and were observed at this same depth in Unit 3 where they seemed to trail off towards the northeast. This cobble-lined floor may relate to the ca. 1890, fullwidth, shed-roofed porch that ran along Wall 5 (refer to Figure 5a).

Excavations along the east-end of Wall 3 found that the Wall 3 foundation extended about $30 \mathrm{~cm}$ to the east, in Units 12 and 3. This wall extension was located at approximately $25 \mathrm{~cm}$ bs. This stub and the foundation that it ties into both appear to be Colonial. A close examination of Smith's 1934 measured drawings failed to locate evidence of this feature (AA-APL, Measured Drawings 1-24-34).

Three gunflints and two strike-a-lites (fire igniting tool) were recovered from along Walls 3 and 4. All five specimens came from four units located at the southeast corner of the ca. 1756 dining room. Two gunflints and one strike-a-lite were recovered from between 0-30 cm bs, and a gunflint and strike-a-lite came from Level 6 (50-60 cm bs). The ceramics recovered from Level $3(20-30 \mathrm{~cm}$ bs) were sparse $(n=7)$, having recovered only six sherds of Goliad ware and one blue on white tin-glazed ware sherd. Over a hundred bone fragments were recovered from Levels 4 and 5, between 45 and $55 \mathrm{~cm}$ bs of Unit 3. This concentration of bone with a comparable collection of ceramics continued into Level 6 (55-60 cm bs). 


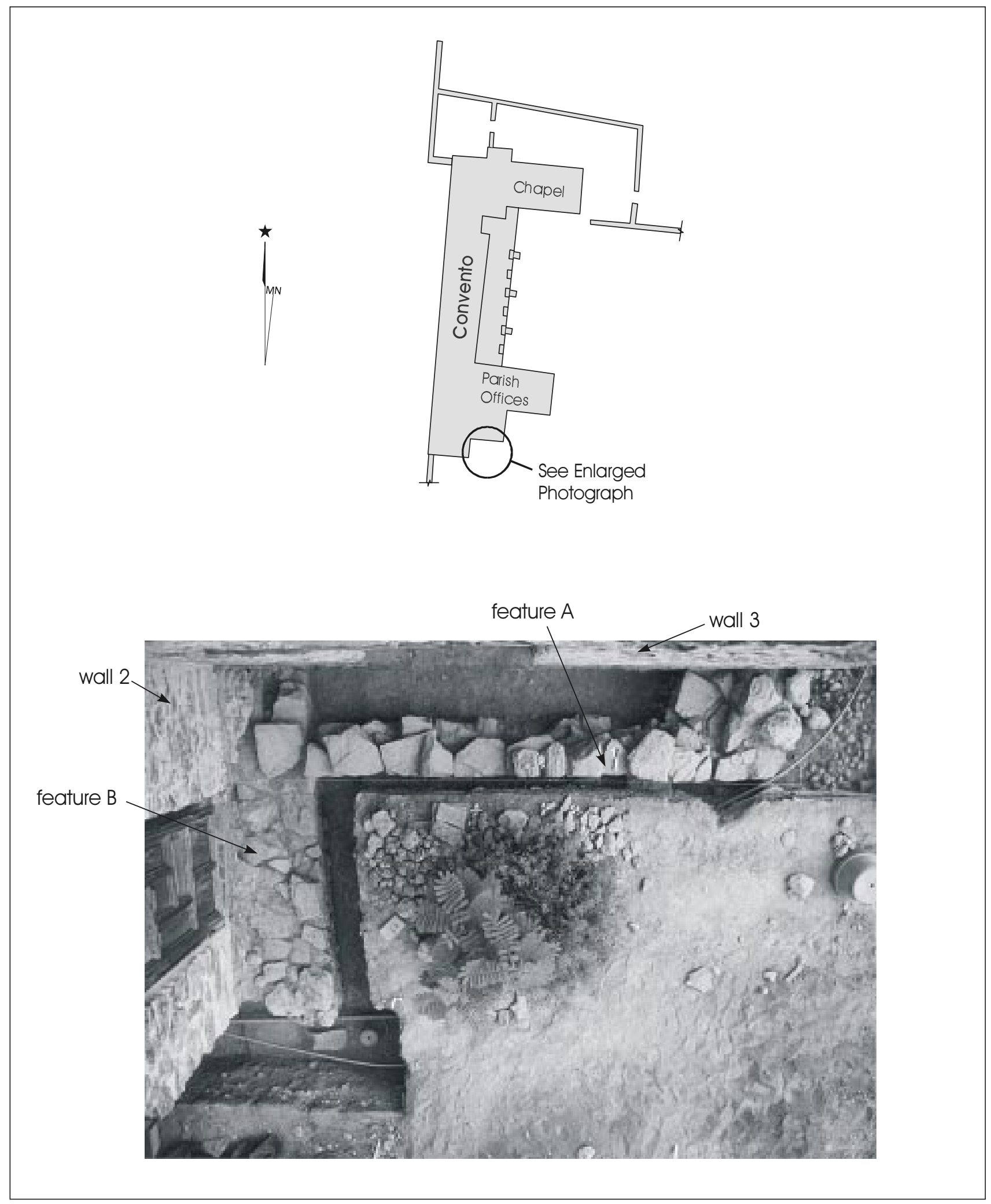

Figure 11. Features A and B-Bird's-eye View.

Note: Taken from ca. $12 \mathrm{ft}$. above surface (not to scale) 
Although no intact deposits were observed in Unit 3, there was a horizontal distribution of artifacts dating to between ca. 1900 and 1980. The twentieth century artifacts were comprised mainly of an assortment of glass fragments $(\mathrm{n}=347,30-50 \mathrm{~cm}$ bs). It was noted that there was an almost even distribution of nails between 40 and $50 \mathrm{~cm}$ bs; a total of 36 wire nails and 30 cut nails were recovered, as were 33 fragments of window glass. This mix of construction-related artifacts would suggest that this material might be attributed to a reconstruction/restoration event. The amount of recovered cultural material decreased considerably between 60 and $90 \mathrm{~cm}$ below surface. A total of 13 ceramic sherds, six fragments of mortar, and two pieces of iron scrap were recovered between 60 and $80 \mathrm{~cm}$ below surface. The only cultural material recovered, between 80 and $90 \mathrm{~cm} \mathrm{bs,} \mathrm{were} \mathrm{five}$ ceramic sherds ( 4 Goliad ware and 1 blue on white tin-glazed ware).

Unit 4 was located at the far north-end of Wall 4, with a $2.7 \mathrm{~m}$ gap (unexcavated) between Unit 3 and Unit 4. Two utility pipes were revealed at $15-20 \mathrm{~cm}$ below surface, and the soils down to $50 \mathrm{~cm}$ below surface appear heavily disturbed. A total of three postholes were located; one in the northwest quadrant and two in the northeast quadrant of Unit 4. The one in the northwest quadrant may have been modern, since it was located $24 \mathrm{~cm}$ south of Wall 4, within a caliche matrix, and between 20 and $30 \mathrm{~cm}$ bs. The postholes in the northeast quadrant were located along the east wall of the unit while the second was about $20 \mathrm{~cm}$ to the west of the first. The posthole along the east wall profile extended from between $22 \mathrm{~cm}$ and $80 \mathrm{~cm}$ below surface, while the second was only visible between 50 and $60 \mathrm{~cm}$ below surface. All three postholes were approximately $20 \mathrm{~cm}$ in diameter.

Based on the excavations of Walls 3 and 4, it appears as though these were constructed on original Colonial period foundations. The cultural levels are disturbed along Wall 3, south of Feature A, and appear to be intact in the area east of Wall 4 (see Figure 2 and Figure 12). The two postholes located within the northeast quadrant may relate to the ca. 1890, full-width, shed-roofed porch that ran along Wall 5 (refer to Figure 5a). These postholes may relate to the vertical poles (supports) for the shed-roof. The minimal disturbance along Wall 4 and the proximity of the poles to this wall probably protected these structural remnants.

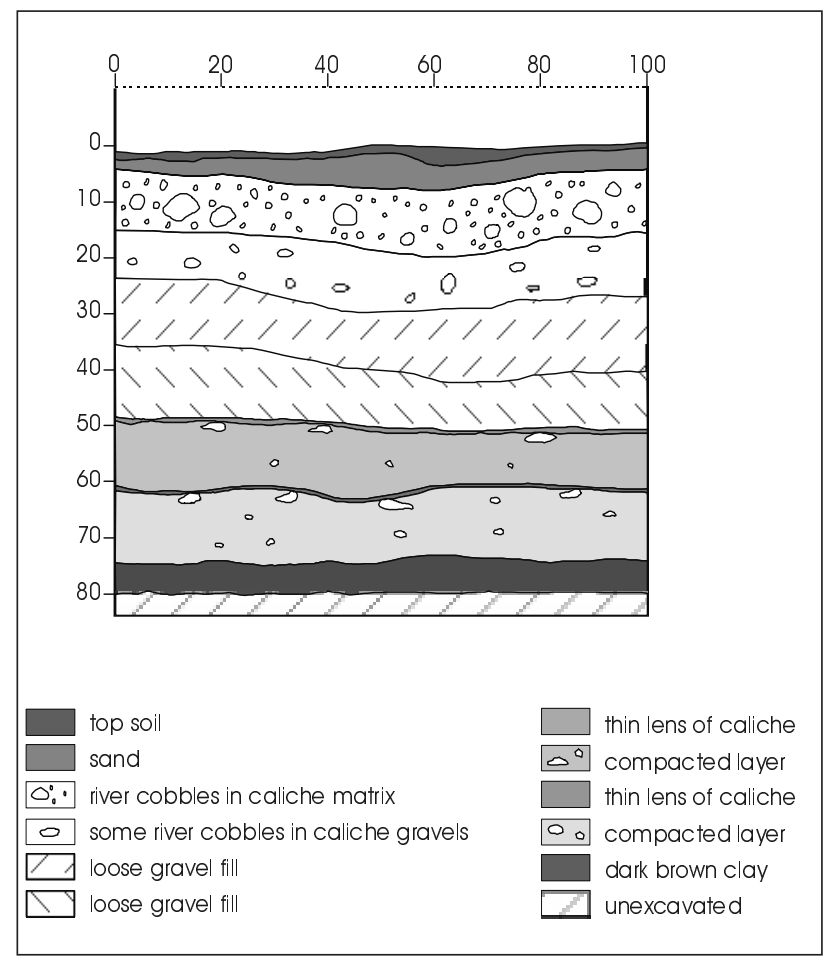

Figure 12. Unit 12 - East Profile. 


\section{Excavations along Wall 5, ca. 1756 Kitchen}

A total of 3 units were excavated along Wall 5, including Unit 4. Only $3 \mathrm{~m}$ of the $6.5 \mathrm{~m}$ length of Wall 5 was archaeologically excavated. Discussion of these excavations follows the units as they occur along Wall 5 from west to east (Units 4, 5, and 6).

Although the Unit 4 excavations revealed disturbed soils down to $50 \mathrm{~cm}$ below surface, at least two Historic period postholes were located within the northeast quadrant of Unit 4. As noted above, these postholes may relate to the ca. 1890 full-width, shed-roofed porch that ran along Wall 5 (shown in Figure 5).

In Unit 5, at about $19 \mathrm{~cm}$ below surface, a section of what appeared to be an intact plastered floor was revealed. This compacted surface was impacted at the north end by what might be restoration-related disturbance, and at the south end by a pipe trench. As the excavation progressed, a horizontal distribution of cobbles was exposed at about $50 \mathrm{~cm}$ bs and continued to $60 \mathrm{~cm}$ below surface. Excavation through this layer of cobbles and subsequent levels failed to reveal additional features. The unit profiles, to the east, west, and south, did not discern these compacted surfaces. A bottle cap, nails, and glass fragments were recovered at Level 8 ( $70-80 \mathrm{~cm}$ bs). Wall fall material $(0-80$ $\mathrm{cm} \mathrm{bs}$ ) consisted of an unidentifiable metal fragment, a glass fragment, and a strike-a-lite.

A pebbled, gravely surface was exposed in Unit 6 at $10 \mathrm{~cm}$ bs. The level directly above this layer of cobbles was heavily disturbed modern fill. Excavation through this layer revealed a mixed deposit, mostly bottle caps and modern glass, which strongly suggests that this layer of cobbles was of recent origin and not part of a Colonial floor feature. A gunflint and strike-a-lite were recovered from within the first $20 \mathrm{~cm}$ of excavated soils. The amount of cultural material recovered dropped considerably between 50 and $70 \mathrm{~cm}$ below surface, and was non-existent between 70 and $80 \mathrm{~cm}$ below surface. No additional features were noted.

It was difficult to discern any intact Colonial deposits along Walls 5 and 6 , as most of the area was heavily disturbed by the installation of utility lines. Given the disturbed deposits, the postholes and compacted surfaces encountered in Units 4, 5, and 6 are probably not of Spanish Colonial origin, but may relate to the ca. 1890 full-width, shed-roofed porch and associated grocery store. The large number of recovered soda bottle caps may relate to this later time period.

\section{Monitoring of Wall Stabilization}

Archaeological excavation of the area to be impacted was concluded in late-August 1999. This part of the investigation cleared an area one meter wide by one meter deep by 25.85 meters long. This then allowed the J. T. Michel, Inc. crew to initiate the wall stabilization efforts. The stabilization work required three distinct tasks:

1. Drill and install eight steel reinforced concrete piers;

2. Excavate and install eight steel reinforced concrete pier caps; and

3. Undercut foundation and install a contiguous concrete foundation beam.

In addition to monitoring the unexcavated areas along Walls 4 and 5, CAR-UTSA also monitored the removal of the wall foundation features along Walls 2 and 3 , and the undercutting of the foundations of Walls 1-5.

The eight piers and pier caps were strategically located along the length of Walls 1, 2, 3, 4, and 5 (see Figure 13). It was evident that the wall stabilization design could not be accomplished without the removal of Features A and B encountered along Walls 2 and 3 (refer to Figure 11). This disassembly allowed for a detailed description of the features.

Features A and B were located at between 10 and 20 $\mathrm{cm}$ below surface, and extended to between 68 and 85 $\mathrm{cm}$ below surface. The width of these features varied. Feature A varied in width in areas due to missing stones -where all stones were intact it measured $80 \mathrm{~cm}$ wide, while Feature B was $60 \mathrm{~cm}$ wide and appeared to be intact. Their construction was composed of three to five courses of rock and, prior to their removal both of the features were extensively photo-documented and illustrated. 


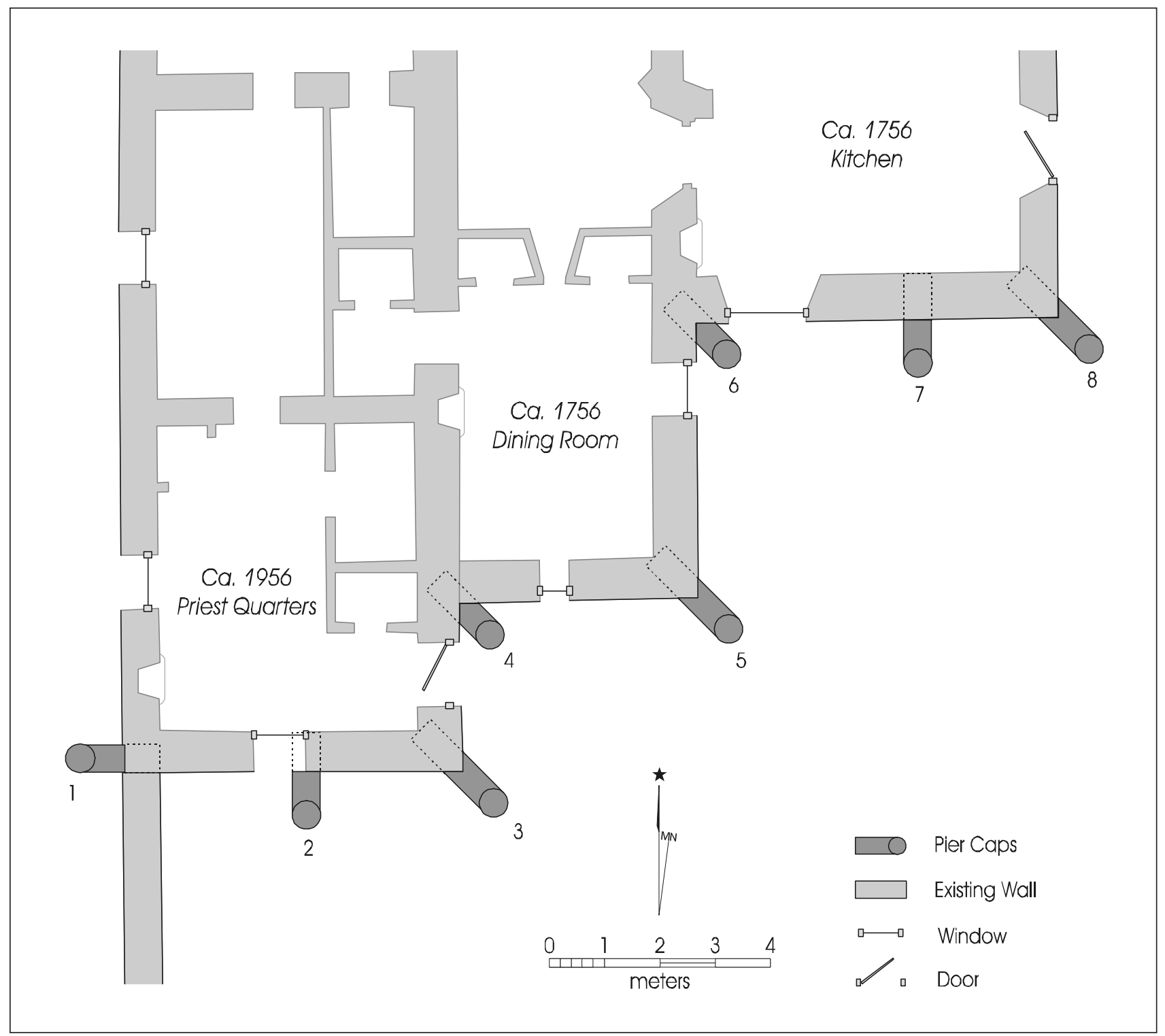

Figure 13. Project Area Plan Map.

Note: Foundation Piers.

Before drilling the $2 \mathrm{ft}$. diameter by $18 \mathrm{ft}$. deep piers, first a 4-ft. square by 4-ft. deep area was excavated to make way for the pier. The four foot deep squares were hand-excavated, beginning at $80 \mathrm{~cm}$ below surface, and then mechanically drilled an additional 18 feet. The second task involved undercutting the foundations directly in front of the piers in order to install the pier caps. These pier caps serve as structural supports for the contiguous concrete beam. Figure 14 illustrates the structural relationship between the piers, pier caps, and foundation footer. The structural integrity of the foundations was not undermined by the initial under- cutting, since a two-foot clayey substratum was left intact. As a result, and since all of the disturbance occurred in culturally sterile levels, CAR-UTSA did not monitor the above-described work.

The monitoring portion of the project began once the eight piers and pier caps were in place and the wall stabilization crew proceeded to undercut the existing foundations. The required undercutting was six inches beyond the width of the existing foundations and was to be completed in four-foot sections. A concern was the possibility that the proposed undercutting might 


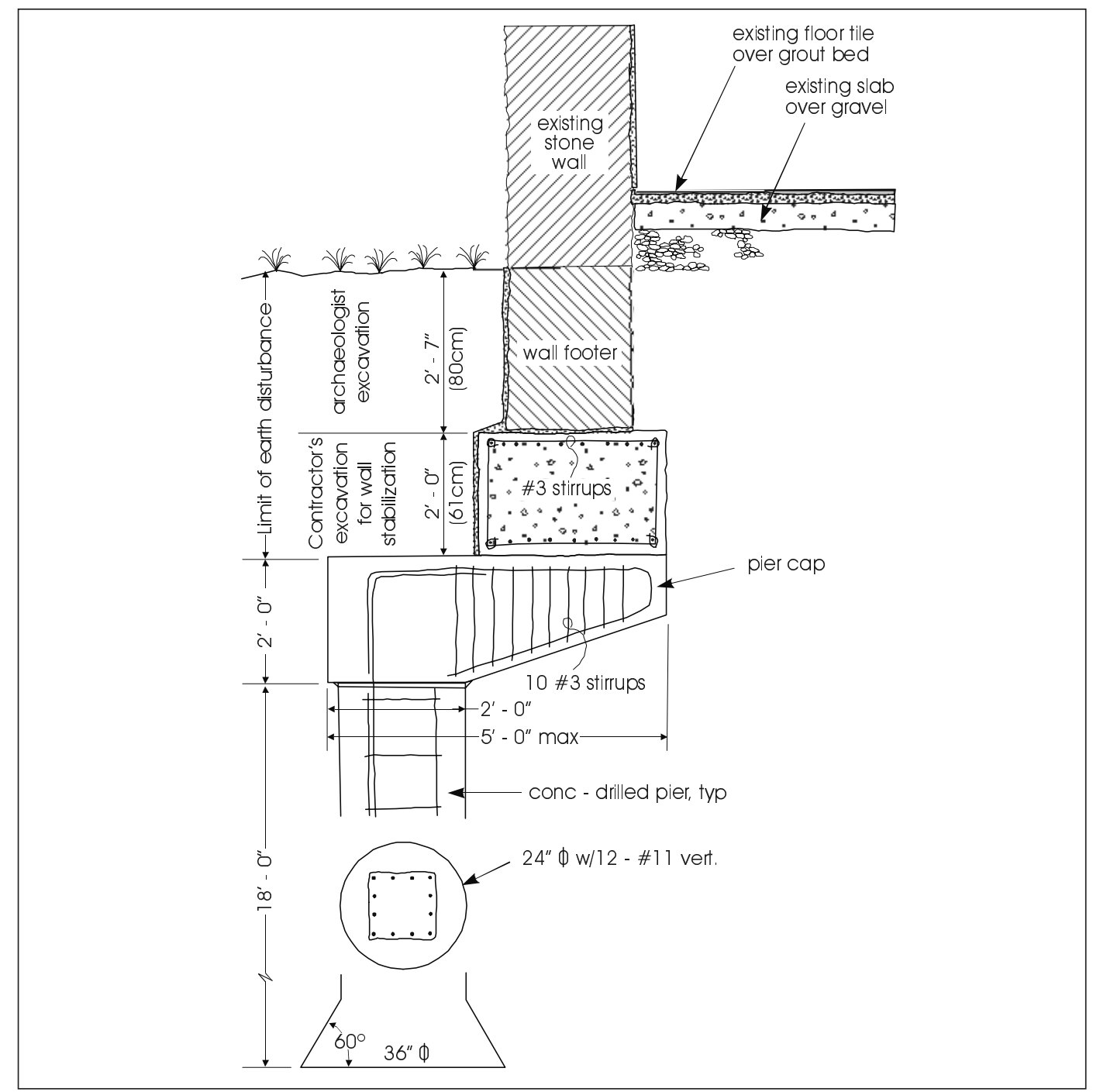

Figure 14. Wall Stabilization Detail.

(from Ford, Powell, and Carson 1999)

compromise the structural integrity of the buildings. This concern was based on the knowledge that these wall foundations are typically constructed of no more than $50 \mathrm{~cm}$ of rock rubble, mud packed into a trench usually the same width as the above-grade wall. These walls were constructed of roughly shaped local stone, set in a sand and lime mortar (Fox and Hester 1976).

Undercutting of the foundation began along Wall 3, at pier beam and cap No. 5 (see Figure 13). Removal of the clayey soils caused the foundation to fail and the loss of approximately one-third of the Colonial period rock-rubble foundation above this cut (see Figure 14). CAR-UTSA notified the Texas Historical Commission and Ford, Powell, and Carson, Inc., of this loss of stone, and all agreed that the work would proceed. Figures $15 \mathrm{a}$ to $15 \mathrm{c}$ illustrates the typical process and results of the wall stabilization work.

Undercutting of the foundation and installation of fourfoot sections of concrete beam continued over a fourweek period, and additional sections of wall foundation were lost in the process. As sections of foundation failed, the remaining stones were temporarily braced while the concrete beam was poured. Once the poured concrete section had hardened, the stones that had fallen were replaced. Some bone fragments and ceramic sherds were recovered during the undercutting, but these came from the soils along the interior of the foundations. No other features were noted during this phase of construction. 


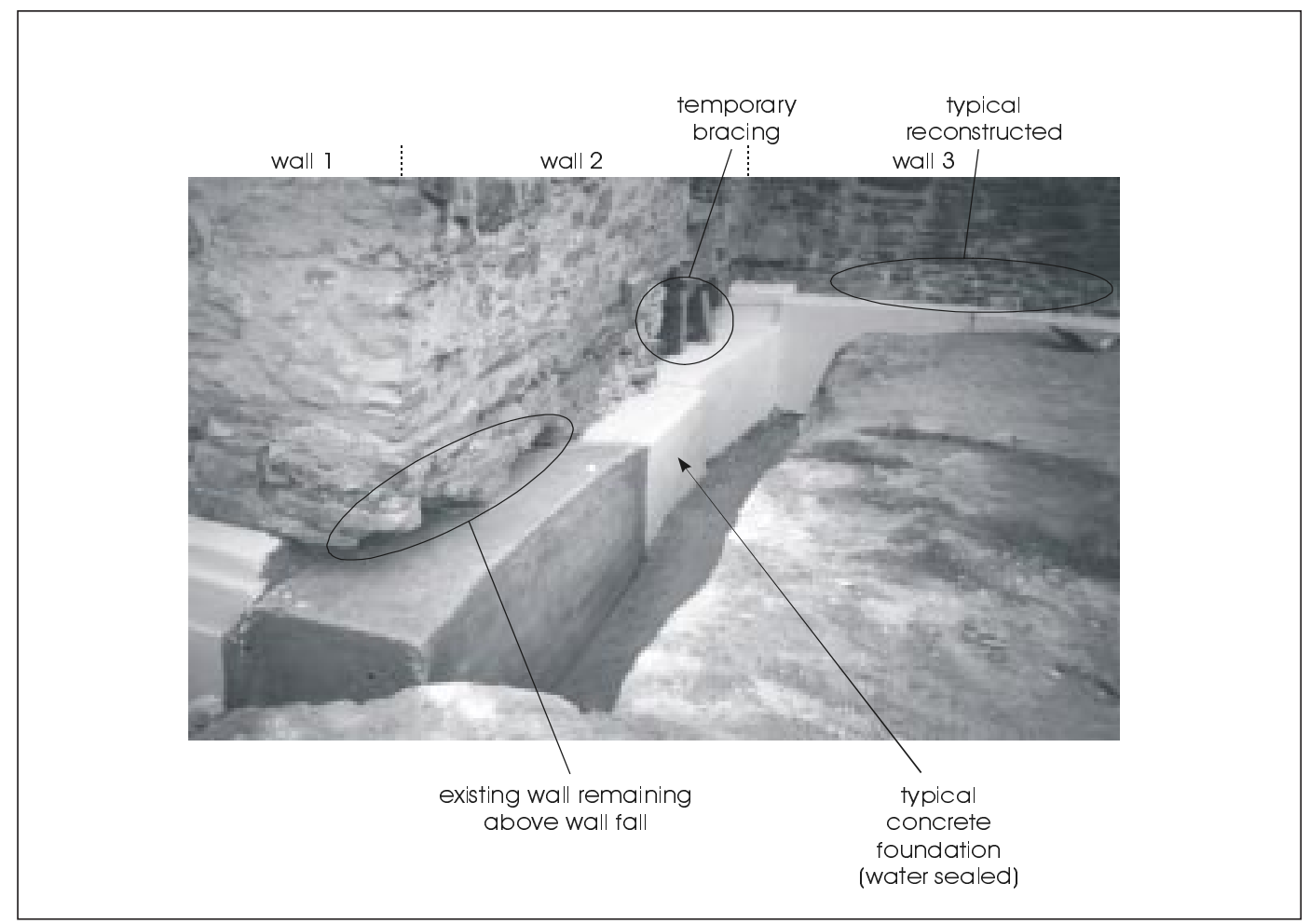

Figure 15a. Walls $2 \& 3$.

Typical Undercutting and New Concrete Foundation.

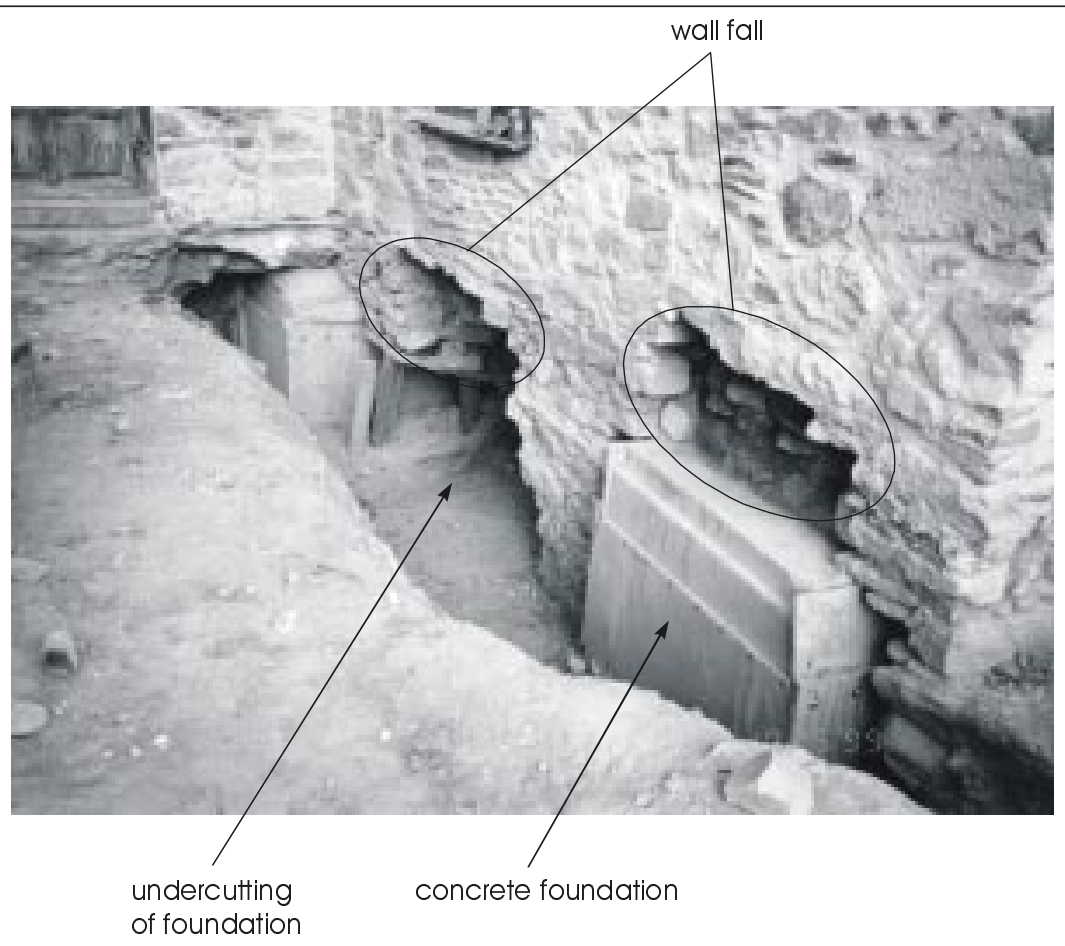

Figure 15b. Wall 3 - Typical Undercutting and New Foundation.

Note: Wall fall above undercutting. 


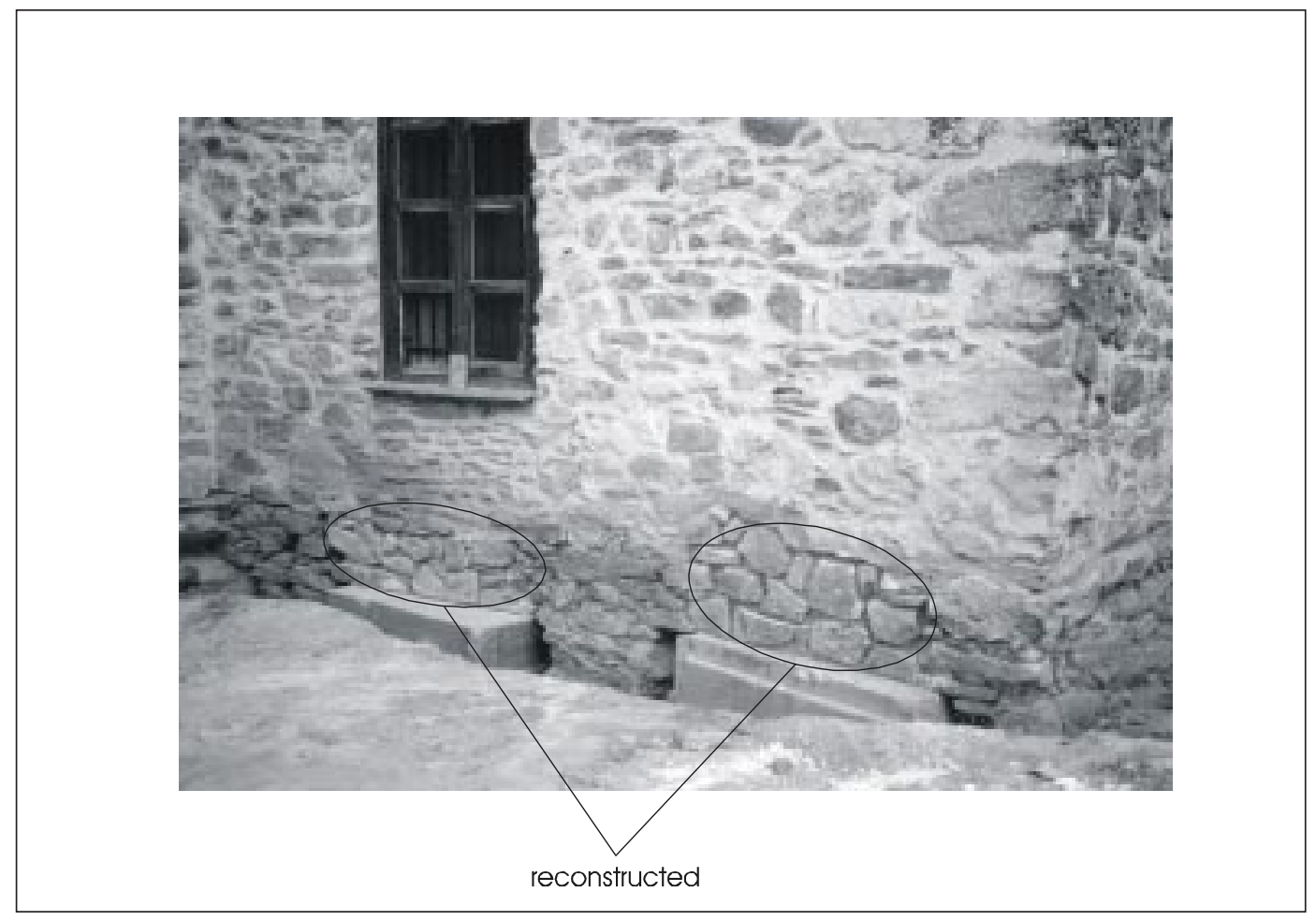

Figure 15c. Wall 3 - Typical Reconstructed Wall Fall.

\section{Depositional Integrity of the Site}

In order to assess the site's depositional integrity, it was necessary to group the area along the walls according to their structural relationship. Figure 2 illustrates the relationship between Walls 1-2 and the ca. 1956 rectory, Walls 3-4 and the ca. 1756 dining room, and Wall 5 and the ca. 1756 kitchen. The artifact summaries in Appendices A and B follow this scheme. Table 2 summarizes the total number of artifacts (excluding faunal and lithic material) recovered from along the south-end walls of the Convento.

In reviewing early plan maps, descriptions, and photos of the Convento, it became obvious that this complex had been considerably altered between ca. 1756 and ca. 1956. Over the years, the Convento tenants had adapted the structures to serve their individual needs. The most obvious alterations were the conversion of the kitchen into a grocery store at ca. 1908, the use of the dining room as a schoolhouse in the early 1900 s, and then the addition of the rectory at ca. 1956.
The importance of the relationship between the rooms and the artifacts was made clear by the fact that $55 \%$ of all the ceramics recovered were from along Walls 3 and 4 (dining room). This is further emphasized by the fact that $73 \%$ of all the bone was recovered from along these same two walls. These findings suggest that the recovery of a large amount of ceramic and bone, from along Walls 3 and 4, relates to the recurring disposal of artifacts which took place along the rear of the dining room.

A comparison of the recovered artifacts, between the rectory (Walls 1 and 2) and the dining room (Walls 3 and 4), is illustrated in Figures 16, 17, 18, and 19. Figure 16 relates to the kitchen and construction-related material recovered from along Walls 1 and 2, and Figure 17 relates to the kitchen and constructionrelated material recovered from along Walls 3 and 4. Figure 18 relates to the amount of Whiteware versus Goliad ware recovered from along Walls 1 and 2, and Figure 19 relates to the amount of Whiteware versus Goliad ware recovered from along Walls 3 and 4. 
Table 2. Summary of Recovered Artifacts (faunal material not included)

\begin{tabular}{|c|c|c|c|c|c|c|c|c|c|c|c|}
\hline Artifacts & $\begin{array}{c}\text { Level } 1 \\
(0-10)\end{array}$ & $\begin{array}{l}\text { Level } 2 \\
(10-20)\end{array}$ & $\begin{array}{l}\text { Level } 3 \\
(20-30)\end{array}$ & $\begin{array}{l}\text { Level } 4 \\
(30-40)\end{array}$ & $\begin{array}{l}\text { Level } 5 \\
(40-50)\end{array}$ & $\begin{array}{l}\text { Level } 6 \\
(50-60)\end{array}$ & $\begin{array}{l}\text { Level } 7 \\
(60-70)\end{array}$ & $\begin{array}{l}\text { Level } 8 \\
(70-80)\end{array}$ & $\begin{array}{l}\text { Level } 9 \\
(80-90)\end{array}$ & Totals & $\begin{array}{l}\text { Percent } \\
\text { of Total }\end{array}$ \\
\hline Chipped Stone & 9 & 13 & 10 & 7 & 13 & 25 & 4 & 1 & 0 & 82 & $.9 \%$ \\
\hline Ceramics & 98 & 209 & 156 & 140 & 107 & 100 & 44 & 30 & 5 & 889 & $9.6 \%$ \\
\hline Kitchen/Household & 621 & 678 & 317 & 286 & 420 & 94 & 66 & 19 & 3 & 2504 & $26.9 \%$ \\
\hline Construction & 1515 & 1199 & 618 & 453 & 443 & 284 & 82 & 31 & 8 & 4633 & $49.8 \%$ \\
\hline Clothing/Personal & 10 & 10 & 3 & 3 & 3 & 1 & 2 & 0 & 0 & 32 & $0.3 \%$ \\
\hline Activity & 1 & 3 & 1 & 3 & 1 & 2 & 0 & 2 & 0 & 13 & $0.1 \%$ \\
\hline Arms & 2 & 3 & 2 & 0 & 0 & 1 & 0 & 0 & 0 & 8 & $0.1 \%$ \\
\hline Barn/Workshop & $\overline{44}$ & 23 & $\overline{13}$ & 17 & 15 & 4 & 3 & 1 & 0 & 120 & $1.3 \%$ \\
\hline Metal & 242 & 135 & 131 & 233 & 29 & 44 & 9 & 5 & 2 & 830 & $8.9 \%$ \\
\hline Miscellaneous & 47 & 75 & 18 & 14 & 10 & 19 & 4 & 3 & 1 & 191 & $2.1 \%$ \\
\hline Grand Totals & 2589 & 2348 & 1269 & 1156 & 1041 & 574 & 214 & 92 & 19 & 9302 & \\
\hline
\end{tabular}

The Figure 16 data indicates an abundance of construction-related material within the first $30 \mathrm{~cm}$ excavated, and the occurrence of construction-related items remains relatively high, between $42 \%$ and $52 \%$, within the last $60 \mathrm{~cm}$ excavated. The Figure 16 data also indicates that the occurrence of kitchen-related items remained relatively low, between $23 \%$ and $46 \%$, throughout the entire $90 \mathrm{~cm}$ excavated.

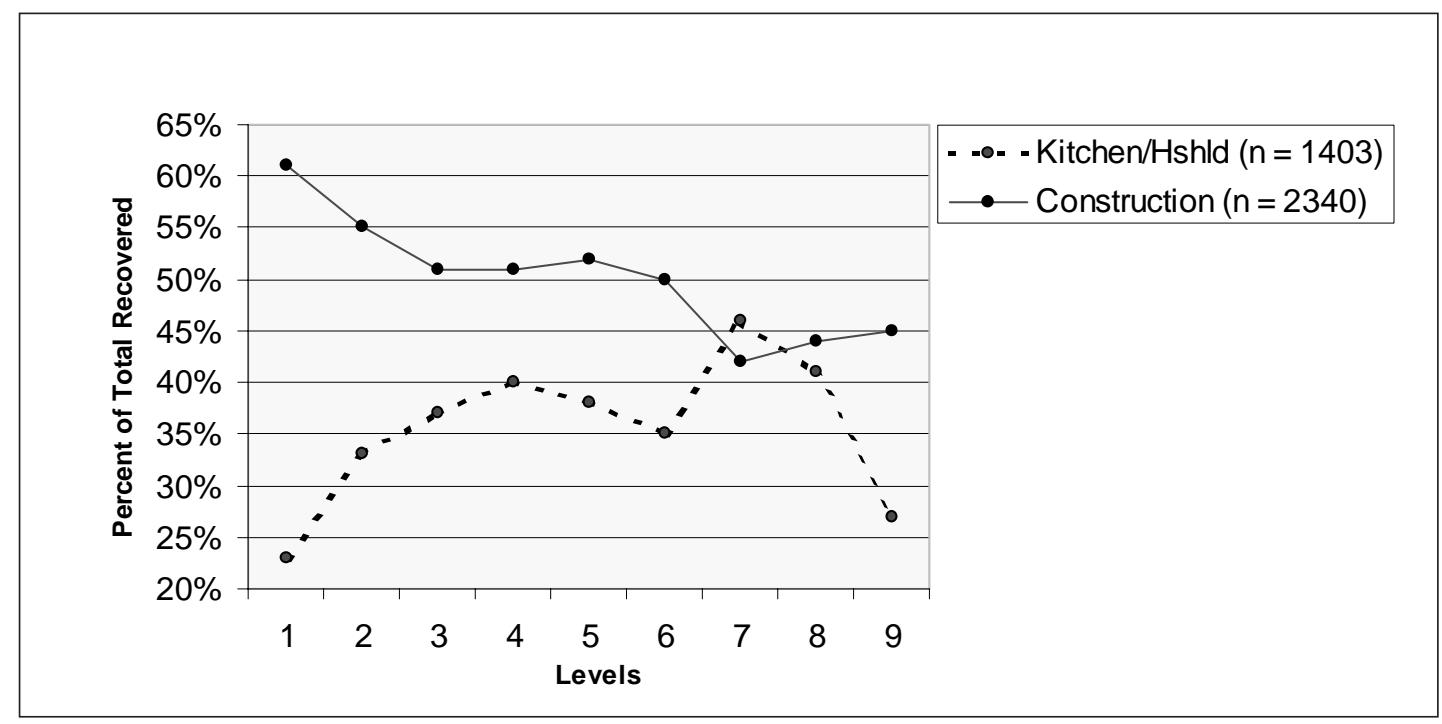

Figure 16. Density of Kitchen and Construction Artifacts, Walls 1 and 2. 
In contrast, the Figure 17 data indicates a steady decline of construction-related items between Level 1 (64\%) and Level 8 (21\%). If not for a sharp increase at Level 5, the data for the kitchen-related items would have also shown a steady decrease, between Level 1 $(23 \%)$ and Level 8 (8\%). The unit level form (Unit 3, Level 5) notes a soil disturbance along the west-end of the unit. This is probably what accounts for the large number of glass fragments $(n=266)$ which caused the sharp increase in kitchen-related items and skewed the data for Level 5.

The Figure 18 and Figure 19 data serve to compare the occurrence of two extremely diverse ceramic types. Although both ceramic types were present in the San Antonio missions during the nineteenth century, Goliad ware is generally less frequent after ca. 1830, while Whiteware is generally more abundant after ca. 1830 (refer to Ceramic analysis section). Ideally then, the archaeological record should reveal a high percentage of Whiteware at Level $1(0-10 \mathrm{~cm})$ and a lower percentage at Level $9(80-90 \mathrm{~cm})$. Conversely, the Goliad ware would be lower at Level 1 and higher at Level 9. The Figure 18 line graph indicates a consis- tently disturbed strata, which can likely be attributed to the installation of below-grade utility lines along Walls 1 and 2.

Figure 19 depicts a classic depositional sequence, with the line graph showing a higher percentage of Whitewares at the upper levels $(0-40 \mathrm{~cm} \mathrm{bs})$ and a lower percentage at the lower levels $(40-90 \mathrm{~cm} \mathrm{bs})$. On the other hand, the frequency of Goliad ware is lower at the upper levels and higher at the lower levels. Additionally, the Figure 19 data reveal a distinct transitional zone between 30 and $40 \mathrm{~cm}$ below surface between both types of ceramics.

As noted in the Results section, the area along Walls 1 and 2 has been heavily impacted by constructionrelated activities over the years; this was clearly illustrated in Figures 16 and 18. In contrast, the area along Walls 3 and 4 has not been as heavily impacted and, as illustrated in Figure 19, the deposition appears to be somewhat intact. An analysis of the Wall 5 data failed to reveal any definite depositional patterns. This is probably owing to the comparatively smaller area excavated and the low number of artifacts recovered.

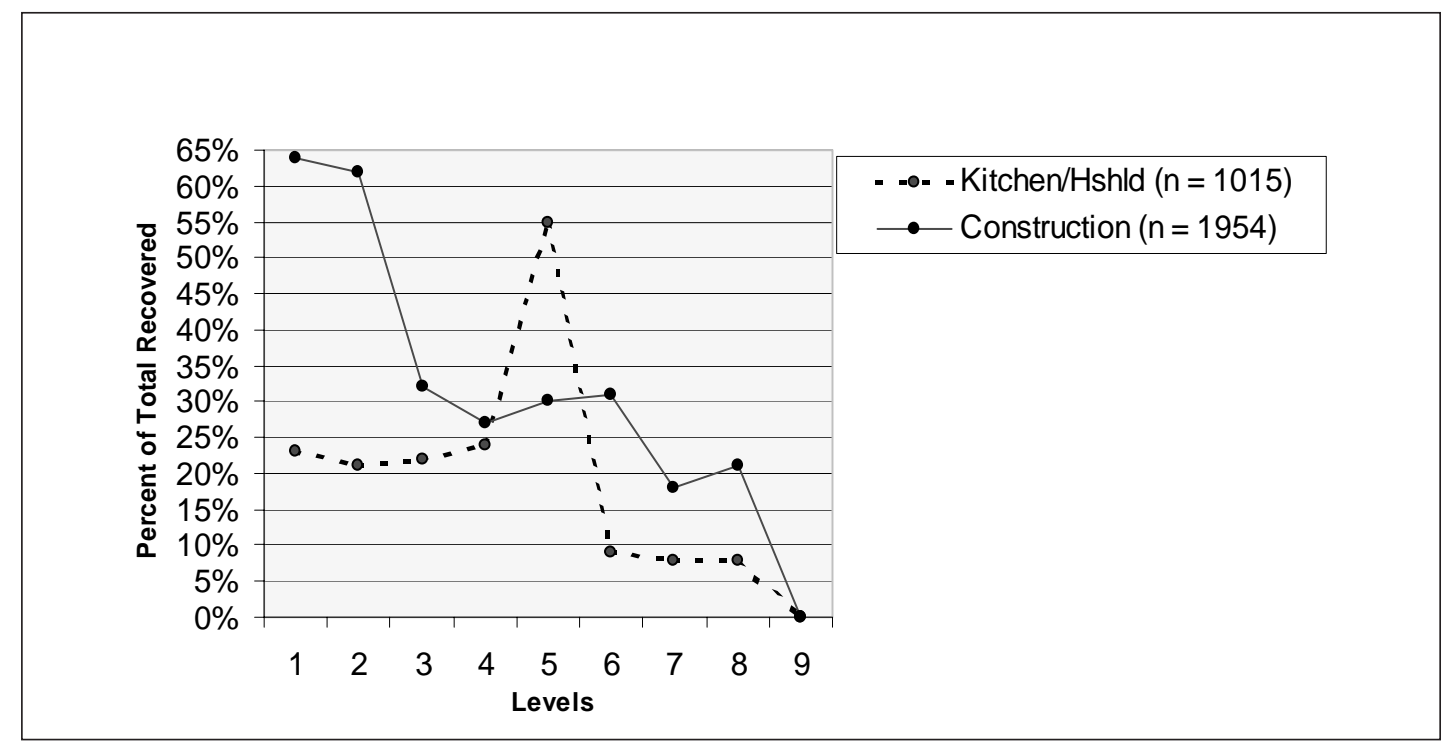

Figure 17. Density of Kitchen and Construction Artifacts, Walls 3 and 4. 


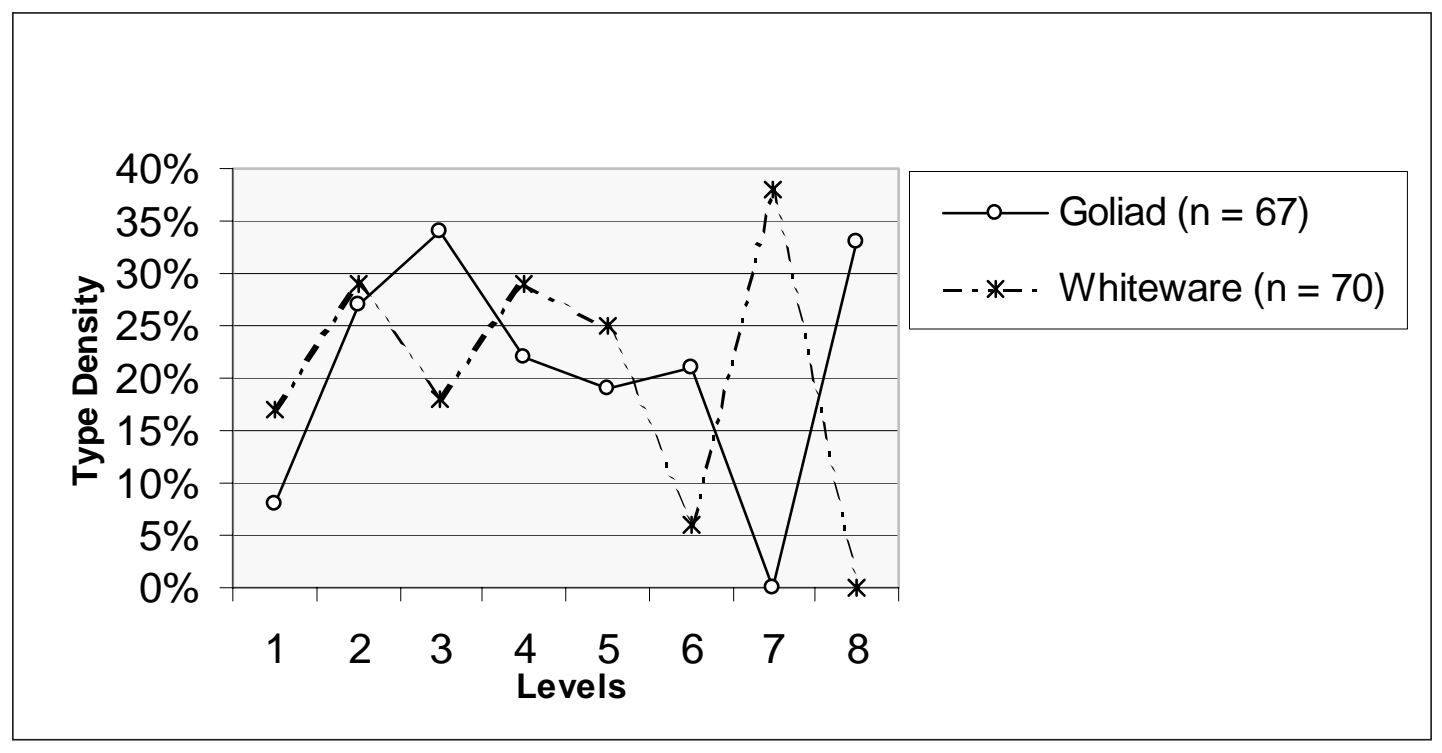

Figure 18. Walls 1 and 2 Ceramics - Whiteware vs. Goliad ware.

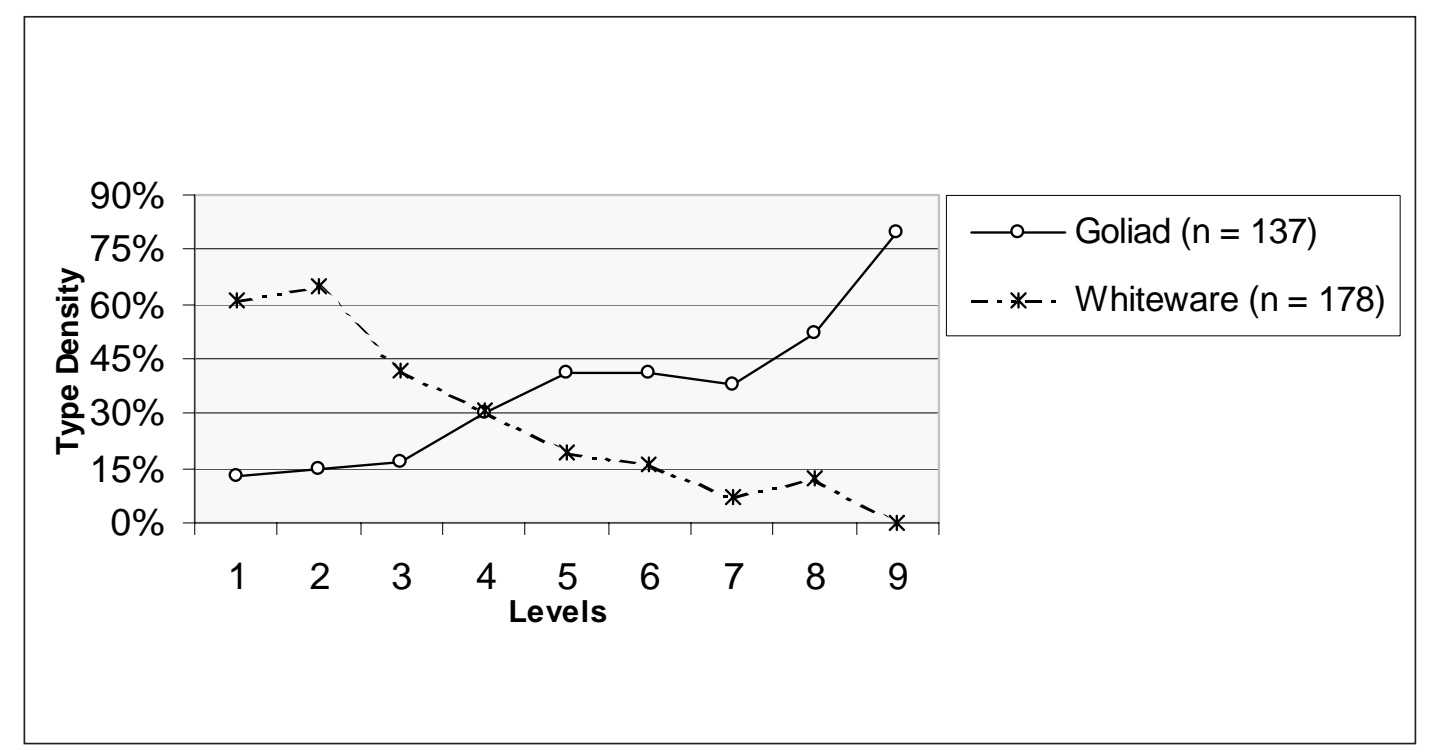

Figure 19. Walls 3 and 4 Ceramics - Whiteware vs. Goliad ware. 


\section{The Artifacts}

\section{Chipped Stone, Ceramics, Other Artifact Types, and Faunal Remains}

Given the extent of the excavations $\left(25.2 \mathrm{~m}^{3}\right)$, it is not at all surprising that a large amount of cultural material was recovered. Well over 16,000 fragments of assorted cultural material was processed (see Appendices $\mathrm{A}, \mathrm{B}$, and $\mathrm{C}$ ). The data were entered into a Microsoft Excel spreadsheet to facilitate the artifact analysis and to determine artifact densities within or between units and levels. The diagnostic artifacts were used to generate approximate occupation dates, which were in turn compared to the archival data.

Although the majority of the artifacts are of the Historic period, these specimens do include a few Prehistoric types (i.e., lithic material), as well as Modern material. The artifact types were sorted and analyzed according to functional category. Major types and categories are Lithics, Ceramics, Kitchen and Household, Construction, Clothing and Personal items, Activity, Arms, Barn and Workshop, Metal Objects, Miscellaneous, and Faunal remains.

The chipped stone material is comprised of chert debitage and flakes, as well as several unique gunflint and strike-a-lite specimens. The gunflints are included in the Arms count and the strike-a-lites are included in the Activity category in Table 9. The other categories include Historic and Modern remains. The domestic groupings include kitchen and household items, such as those related to the preparation, serving, consumption, and storage of food or drink. Although this latter category includes ceramics, the specialized nature of ceramic analysis requires that these artifacts be considered separately. The construction category refers to items related to architecture and building remains (e.g., nails, brick fragments, and window glass). The clothing and personal category considers items of individual use such as buttons, jewelry, and grooming. The activity grouping consists of toys and writing material. The arms category consists of items that relate to firearms and ammunition. The barn and workshop grouping includes artifacts related to working in a shop (e.g., tools, horseshoes, and machinery). The metal grouping consists of an assortment of undiagnostic scrap metal and other unidentified metal items. The miscellaneous category considers items that may be classified in more than one grouping, or may simply be unidentifiable. The faunal category includes a rather large volume of vertebrate faunal remains, much of which was of great analytical value.

\section{Chipped Stone}

\section{Steve A. Tomka}

A total of 91 chipped lithic artifacts was recovered during the excavations at the Priest quarters and adjacent the southwest corner wall at Mission Espada. The majority (85\%) of the collection consists of 77 pieces of unmodified lithic debitage. The remaining specimens $(n=14,15 \%)$ are categorized into the following functional groups: one arrow point fragment, five gunflints, four strike-a-lites, two scrapers, and a single core (Table 3 ). In addition, a single unifacially flaked artifact is classified as an indeterminate uniface due to its small size and fragmentary nature. Tool function was determined by low-powered $(20 \mathrm{x}-80 \mathrm{x})$ micro-wear analysis.

\section{Arrow Point}

A single stem fragment is classified as an arrow point. It was recovered from Level $3(20-30 \mathrm{~cm}$ bs) in Unit 6 (Figure 20a). Judging from its widely expanding stem, its concave base, and narrow neck, it is likely to 

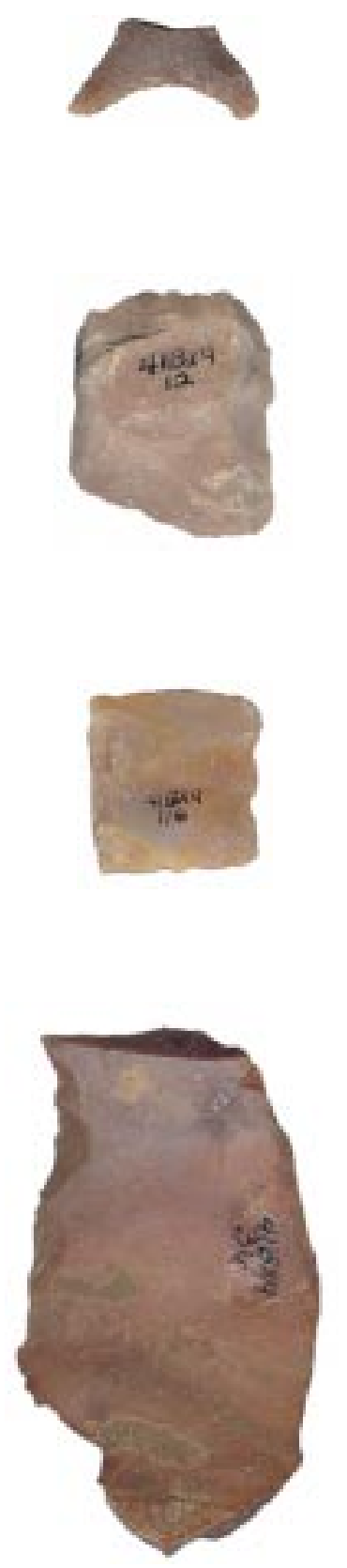

C

b
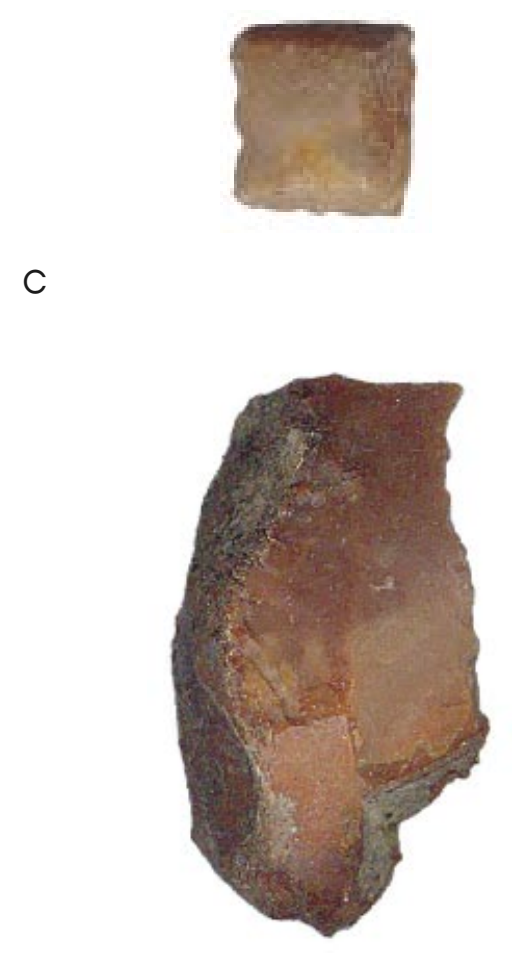

d

a. Edwards arrow point stem fragment

b. gun flint

c. gun flint (French origin)

d. strike-a-lite

Figure 20a-d. Chipped Stone from the current project. a) Edwards Arrow Point and Stem Fragment; b) Gunflint; c) Gunflint (French origin); d) Strike-a-lite. 
represent an Edwards arrow point (Turner and Hester 1993). This point was first defined by Sollberger (1978), who believed that the type may have been the earliest arrow point to appear during the Late Prehistoric period in south-central Texas. Hester (1971) recovered Edwards points from the La Jita site in northeastern Uvalde County. They were found in levels dating to A.D. 930 (Hester 1971:114). Hester (1971) estimated that the type dates between A.D. 930 and 1040. At site 41BX377, at Camp Bullis, some 220 Edwards points were recovered. A charcoal sample from $10-15 \mathrm{~cm}$ below surface, where the majority of the points were recovered, was dated to A.D. $1060 \pm 70$ (TX2771). A large number ( $\mathrm{n}=88$ ) of Edwards points also were found at Scorpion Cave, although the levels were never dated (Highley et al. 1978). In general, the type seems to occur along the south-southeastern edge of the Edwards Plateau particularly in Uvalde, Kerr, and Bexar counties (Mitchell 1978).

Given that the type is not thought to be associated with Historic mission occupations, it is likely that the find is an indication of the presence of a Late Prehistoric occupation underlying mission period debris. Alternatively, it is possible that the specimen is the product of recycling of Prehistoric material by mission residents.

\section{Gunflints and Strike-a-lites}

Five gunflints and four strike-a-lites were identified. Three of the gunflints have a roughly rectangular shape and are made on tertiary $(\mathrm{n}=2)$ and secondary $(\mathrm{n}=1)$ hard hammer stone flake blanks (Figure 20b). They are only marginally retouched, most of the invasive flake scars that penetrate the face of the specimens result from use. A fourth specimen is a bifacially flaked trapezoidal gunflint. Use-related crushing is evident along all edges and moderate polish is present on flake scar ridges of both faces. These four gunflints are made of locally available tan to brown colored fine-grained chert. The final gunflint is made on a nearly square midsection of a trapezoidal blade (Figure 20c). The four edges are unifacially retouched on the dorsal face and form steep angles. Use-related step fracturing is present on the ventral face of the specimen only along one edge. In terms of morphology and manufacture technology, the specimen matches classic Europeanmade gunflints (Kent 1983). Use-wear, in the form of crushing and step fracturing, is present in both blade margins and on alternate faces of the two broken ends of the midsection. The honey-colored flint is characteristic of French-made gunflints imported from Europe (Kenmotsu 1990:96; Prewitt personal communication, 2000). French gunflints were the most common gunflints used in the American colonies prior to A.D. 1800. The English-made Brandon gunflints began arriving to America in quantity only after 1790 (Kenmotsu 1990:96) and they have a black to opaque gray appearance. Given that it was recovered from outside the window of the Priest quarters occupied by Father Bouchu, a French Franciscan missionary, it is possible that it was a specimen that may have been in his possession. It is not known whether he would have purchased or acquired the gunflint in Texas or Mexico or brought it with him from France. Certainly, the supply of European goods to the New World was well established by the mid-1800s when Father Bouchu arrived at Mission Espada and he could have easily acquired a French-made gunflint once in Texas.

Three of the four strike-a-lites are unifacially retouched artifacts representing recycled Prehistoric scrapers. All three are of fine-grained dark gray to brown chert blades or blade-like flakes. Dorsal cortex is present on all specimens and may be a purposeful design feature to enhance gripping. The multiple "working-edges" on all three specimens are characterized by heavy crushing verging on rounding distributed along the dorsal face of the artifacts. A few isolated irregularly spaced flake scars are also present on the ventral face of the specimens but are not evident along all utilized edges. The fourth strike-a-lite is a longitudinally curved distal blade fragment (Figure 20d). Crushing and step-fractured flake scars are distributed along the ventral face of one longitudinal edge. The opposite edge appears to also have been used although use-wear is light. The corticate dorsal surface adjacent this edge may have prevented the generation of sparks along this edge. 


\section{Scrapers}

Two scrapers were recovered during the Mission Espada excavations (Table 3). Based on the degree of retouch on their working edges, one is a minimally retouched end scraper and the other has one minimally retouched and one expedient working edge (i.e., edge modified by use not retouch). Based on the location of their working edges, the first specimen is an end scraper, while the other is a combination end/side scraper. The minimally retouched end scraper is made on a secondary hard hammerstone flake, the combination end/side scraper is on a small tertiary flake.

\section{Indeterminate Uniface Fragment}

A single unifacially retouched flake fragment is included in this category. This specimen could not be classified into existing functional tool categories (e.g., end or side scrapers, or knives, etc.) due to its fragmentary nature. The specimen has a retouched edge (Table 3 ) and it is too incomplete to allow meaningful measurements of dimensions.

Table 3. Lithic Tool Characteristics by Category

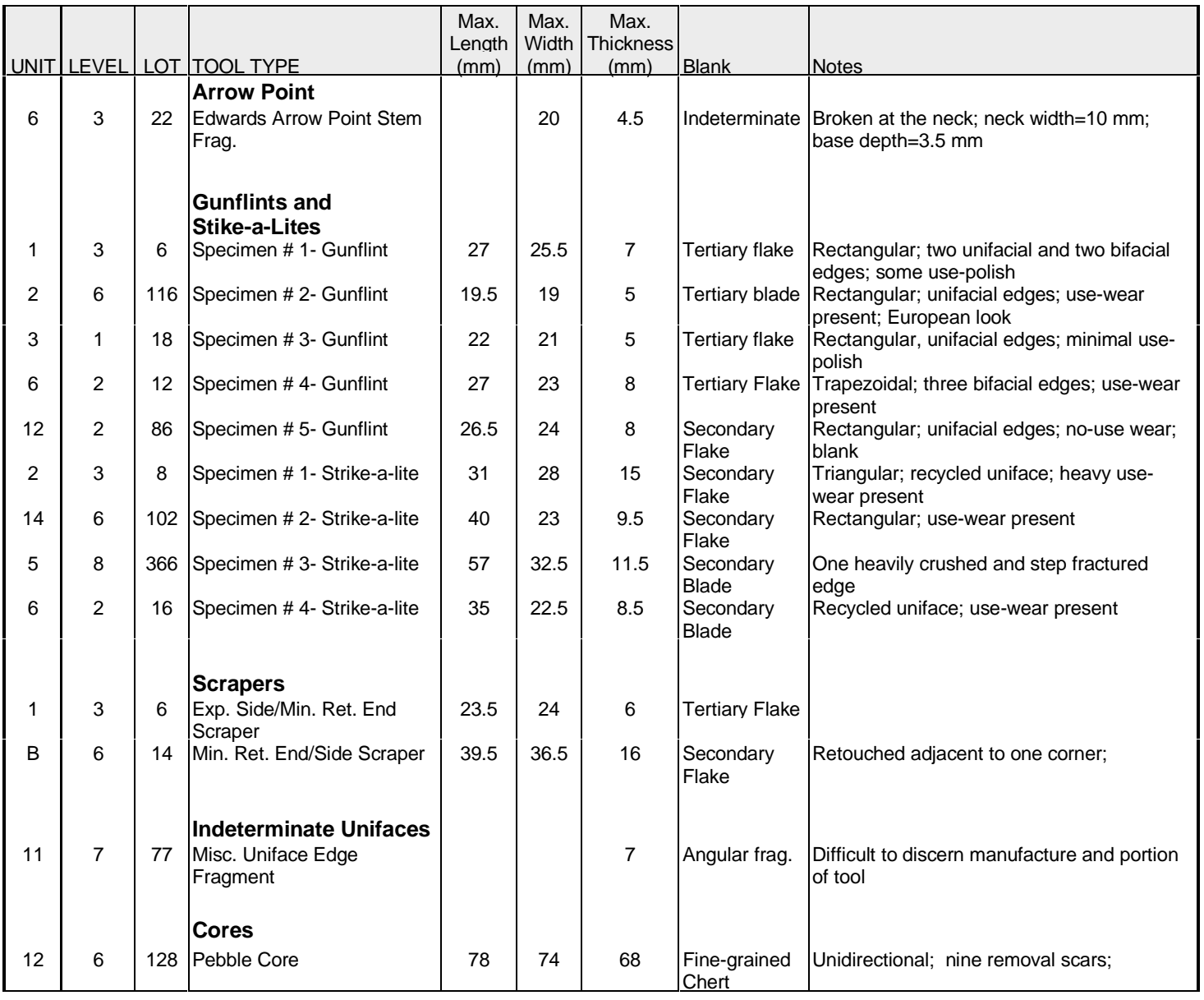




\section{Unmodified Debitage}

A total of 79 unmodified debitage was recovered from excavations at the Priest quarters and adjacent the southwest corner wall at Mission Espada. The majority $(n=72 ; 91 \%)$ of these are from the excavations associated with the Priest quarters (EUs 1-16). Only seven (9\%) are from EUs A and B adjacent the southwest corner. The five EUs (1, 2, 11, 12, and 14) along Wall 3 contain the largest total number of debitage $(n=25)$, followed by the seven EUs along Wall $1(n=20$; A, B, 7-9, 13, 16) and EU 3 along Wall $4(n=20)$.

Of the 79 specimens one came from trench fill. The level by level distribution of the remaining 78 specimens has a bimodal pattern (Figure 21). A smaller peak of 13 specimens is present in Level 2 below which debitage counts decrease through Levels 3 and 4. Counts begin increasing in Level 5 peaking with 23 specimens in Level 6. At least two explanations may account for this pattern. A single occupation zone buried between $50-60 \mathrm{~cm}$ below surface is present at the site and the smaller debitage peak in Level 2 represents specimens translocated through post-depositional disturbance (e.g., construction activities) from the original construction of the Priest quarters. Alternatively, the two debitage peaks represent distinct occupation zones with the deeper zone potentially dating to the early part of the Late Prehistoric period (e.g., Edwards point) and the upper zone representing the Protohistoric/mission era occupation.

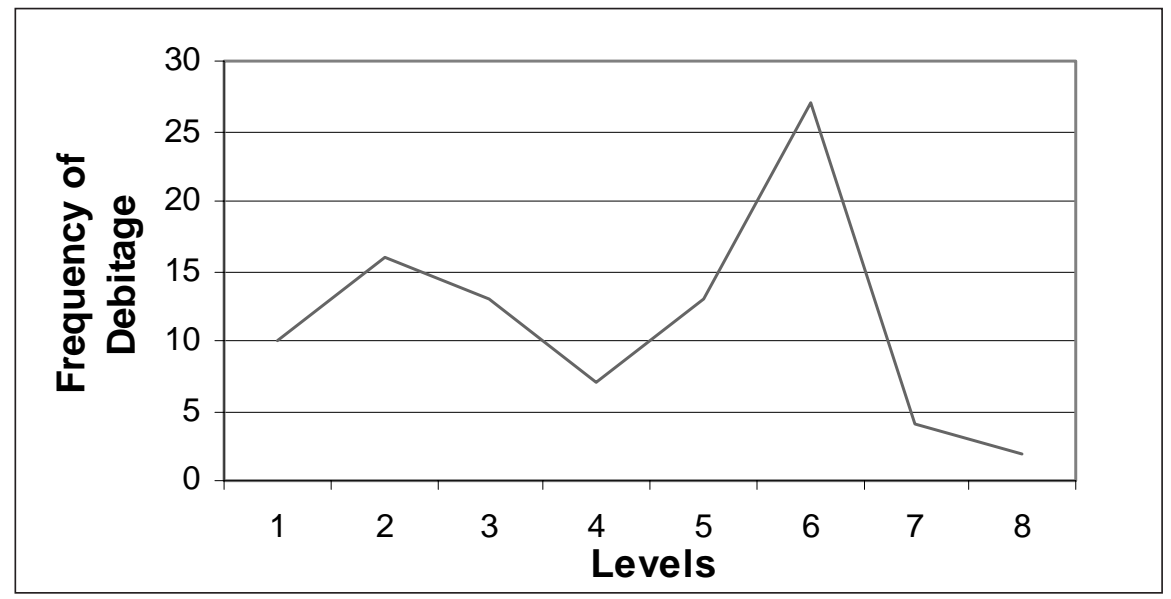

Figure 21. Distribution of Unmodified Lithic Debitage by Level.
To investigate the possibility that the two debitage peaks represent distinct occupation zones it was decided to investigate the mean size of unmodified debitage by excavation level. It is assumed that debitage collections derived from the downward movement of artifacts from living surfaces should be smaller in overall sample size as well as in mean average size compared to collections derived from actual living surfaces themselves. That is, the smaller the size of the debitage, the deeper it can move below the original living surface on which it was deposited. It is also possible that bioturbation will result in the upward movement of some small debitage through a soil profile.

Since debitage was grouped into $10 \mathrm{~mm}$ size classes, it was decided to use the mean of each size class as the mean of the flakes within the size class (i.e., 5 $\mathrm{mm}, 15 \mathrm{~mm}, 25 \mathrm{~mm}$ for size classes $1-10 \mathrm{~mm}, 1-20$ $\mathrm{mm}$, and $21-30 \mathrm{~mm}$ respectively). To derive the mean size of the debitage from a level, the number of flakes within each size class was multiplied by the mean size of the class and the results were summed and divided by the total number of debitage within the level. The results of these calculations as well as sample sizes and the percentages of flakes in the two smallest (1-10 and 11-20 mm) size classes combined are shown in Table 4.

Mean debitage size tends to increase from Level 1 to Level 3 and drops in Level 4. Level 5 has the highest mean flake sizes with the mean dropping slightly in Level 6. Levels 7 and 8 have small sample sizes $(n=4$ and $n=1$, respectively) reducing their utility for this trend analysis. These patterns do not support the proposition that the peaks in Levels 2 and 6 represent distinct occupation surfaces. When the mean debitage size figures are compared for the top four levels combined and the bottom four levels combined, an interesting pattern emerges. Debitage from the bottom four levels is somewhat larger in mean size $(23.0 \mathrm{~mm} ; \mathrm{n}=40)$ than the debitage found in the upper four levels $(20.1 \mathrm{~mm} ; \mathrm{n}=37)$. These debitage size patterns do not sup- 
Table 4. Breakdown of Mean Debitage Size Characteristics by Level

\begin{tabular}{|c|c|c|c|c|c|c|c|c|}
\hline & Level 1 & Level 2 & Level 3 & Level 4 & Level 5 & Level 6 & Level 7 & Level 8 \\
\hline Mean Size & 18.3 & 20.4 & 21.25 & 20.7 & 22.7 & 21.4 & 32.5 & 25 \\
$\mathrm{n}$ & 9 & 13 & 8 & 7 & 13 & 22 & 4 & 1 \\
$\%$ in 1-20 mm & 67 & 61.5 & 50 & 71 & 46 & 50 & 0 & 0 \\
\hline
\end{tabular}

port the suggested presence of two isolated cultural zones present at the site. On the contrary, the patterns seem to be consistent with the alternative suggestion that a single component has been upwardly disturbed during construction activities or from bioturbation at the site.

As a final check on the likelihood of the two debitage peaks representing distinct components the technological characteristics of the combined debitage sample from the upper four levels $(n=37)$ was compared with that of the lower four levels $(n=40)$. The comparisons indicated that the percentage of tertiary specimens is nearly identical in the two samples (about $60 \%$ ). Complete flakes constitute 40 percent of the upper debitage sample, while they represent only 30 percent of the lower sample. Given that core reduction strategies tend to produce higher proportions of complete flakes than bifacial reduction (Sullivan and Rozen 1985, Tomka 1989), it is possible that the differences in debitage completeness reflect differences in reduction strategies between the two samples. This possibility is strengthened by the platform faceting data. A total of 56 percent $(n=13)$ of the platform-bearing debitage from the upper four levels is single faceted. In contrast, only 35 percent of the platform-bearing debitage from the lower four levels fall in the same category. Even when corticate and single faceted platforms are lumped, the deeper levels have smaller percentages of such flakes than the upper four levels. Although these patterns are strongly suggestive of a technological difference between the two samples, the analysis of the flake type breakdowns identified only one significant difference between them. Angular debris constitutes about 20 percent $(n=6)$ of the debitage from the deeper levels, while it is only 11.5 percent $(n=3)$ of the upper sample.
The distribution of debitage by size classes indicates that 11-20 $\mathrm{mm}$ specimens dominate the upper sample $(\mathrm{n}=22,59 \%)$, while the same size class constitutes only 35 percent $(n=14)$ of the lower debitage sample. Overall, debitage in the $20-30$ and $30-40 \mathrm{~mm}$ size classes constitutes about 58 percent $(n=23)$ of the sample from the lower levels compared with 38 percent $(n=14)$ for the upper four levels.

The vertical distribution of Goliad and Whitewares suggested that the lower deposits in Trenches 3 and 4 might be undisturbed. To investigate the possibility that some of the patterns suggested in the debitage analysis may be more clearly discernible within these units, the analyses were repeated on the sample of 49 flakes from Units 1, 2, 11, and 14 along Trench 3 and Units 12, 3, and 4 along Trench 4.

The patterns in the vertical frequency distribution and the mean size of the debitage by level were nearly identical to that noted in the larger sample examined. In addition, the patterns noted in debitage attributes from the two trenches did not vary from that described for the larger sample. Finally, the comparison of debitage characteristics of specimens from the upper four and the lower four levels of the two trenches produced the same general patterns as that identified for the larger sample of debitage.

These similarities are in part conditioned by the fact that the Trench 3 and 4 materials were a subset of the overall sample and therefore should be similar to the larger sample. Nonetheless, the patterns in the debitage attributes for the subsample from Trenches 3 and 4 does not help to clarify the question of disturbance in the deposits adjacent the Priest quarters and southwest corner. 
Overall, the lithic technology evident in the small Mission Espada collection suggests that flintlock guns were used at the mission since its initial occupation in the 1730s and fire-making technology had begun to or had shifted to EuroAmerican techniques, using strike-a-lites rather than the more traditional fire drill and hearth method. Interestingly, Guerrero points, numerous at other Texas missions, were not recovered from the excavations. The lack of these stone arrow points may be explained by the proximity of the excavation units to the Priest quarters and the likelihood that the artifacts recovered there were used primarily by the Franciscan inhabitants of the mission rather than the Indian neophytes. This interpretation is strengthened by the recovery of a French-made gunflint that may have been imported and used by Father Bouchu.

Much of the previous discussion has focused on identifying distinct components within the small lithic debitage sample recovered from Mission Espada. Although some data supports the possibility (e.g., technological characteristics) other information seems not to lend support (e.g., mean debitage size) to this interpretation. Unfortunately, the vertical distribution of non-debitage artifacts recovered from the site also is inconclusive. Four of the five gunflints, two strike-alites, one of the two scrapers, and the Edwards arrow point stem are from the upper $30 \mathrm{~cm}$ of deposits. While no tools were recovered in the next $20-\mathrm{cm}$, two strikea-lites, the French gunflint, a scraper, and the single core were recovered from $50-80 \mathrm{~cm}$ below surface. These distributions do not reflect two distinct clearly isolable archaeological components.

The overall scarcity of formal unifacial and/or bifacial tools is consistent with lithic assemblages from other missions (D. E. Fox 1979; Hester 1977; Tomka and A. A. Fox 1998, 1999) where expedient tool forms dominate the collections. Raw material reduction strategies, as reflected in the small sample of lithic debitage, are dominated by uni- or bi-directional core reduction to produce blades and gunflint blanks. Bifacial reduction appears to be employed in the shaping of some gunflint blanks.

In summary, the mean debitage size patternings do not support the existence of two distinct archaeological components at Mission Espada. However, the comparison of debitage samples from the upper and lower levels of the site does reveal some interesting technological differences between the small samples. Contrary to the mean debitage size data, these differences seem to support the suggestion that two distinct components are present in the excavation units adjacent to the southwest corner and Priest quarters. Finally, the vertical distribution of the tools recovered from these units indicates a great deal of homogeneity between the upper $(0-40 \mathrm{~cm}$ bs) and lower (50-80 $\mathrm{cm}$ bs) deposits of the site. 


\section{Ceramics}

Anne A. Fox

The ceramic collections found at the San Antonio missions are all very similar. This is probably due to the fact that most of the supplies for the settlement came from Mexico on the same mule trains, and the occupation dates for all the missions were very similar, from about 1720 to 1795 . In addition, the later history of all the missions after secularization progressed in much the same way. Local townspeople moved into the missions, creating small villages at each of the sites. As Texas broke away from Mexican control, Mexican-made ceramics were rapidly replaced by British wares which were brought into Texas by sea from Europe, New Orleans and cities on the east coast of the United States.

A total of 889 ceramic sherds was recovered. The entire collection of ceramics are presented in Appendix B. Some of the more interesting examples of majolica, lead glazed, and whiteware are presented below.

\section{Unglazed Wares}

\section{Goliad Ware}

There was just one ceramic type that arrived with the mission Indians and continued in use throughout the missions and the town well into the nineteenth century. This is a brownish to red colored ware tempered with varying amounts of bone, today referred to as Goliad ware. This ware displays a wide variation in surface color and hardness, due in part to the fact that it was hand built and fired over an open fire rather than in a kiln. Cores of the sherds are often gray to black owing to the low temperature of the firing.

Vessels represented in this collection are primarily limited to bowls of various sizes and mediumsized jars (Mounger 1959).

\section{Wheel Made Unglazed Ware}

Also represented in this collection are unglazed sherds from wheel made vessels. The paste contains a high proportion of sand with numerous black and occasional red inclusions. It is very similar to that of the Sandy Paste Lead Glazed ware described below, but there is no trace of glaze on the sherds.

\section{Valero Ware}

A number of unglazed, wheel thrown sherds from large vessels have red painted designs. These have been tentatively named Valero Ware (Ivey and Fox 1981:31) when found in other Colonial sites in San Antonio.

Large sections of jars with this type of decoration are on display at Presidio La Bahia in Goliad.

\section{Tonalá Burnished Ware}

Unglazed burnished wares are commonly found on Colonial sites in Texas, and are direct descendants of Mesoamerican pre-Columbian Indian ceramics. A tan-bodied ware with burnished red slip or tan slip with red, black, and yellow designs has been identified as coming from Tonalá, Jalisco.

A few sherds of this type appear in this Mission Espada collection.

\section{Red Burnished Ware}

A red-bodied highly burnished ware with matte areas decorated with burnished designs is also common on Colonial sites in the San Antonio River valley. Numerous small spalls often give the surfaces a speckled appearance. Several such sherds are in this collection. A black version of this type is also occasionally found.

One such sherd is in this collection.

\section{Flower Pots}

In contrast to these unglazed types in this collection are sherds of modern flower pots such as are still in use today. Probably pressed into a mold and fired in a kiln, these familiar orange brown colored pots with a hole in the base have evidently been in use for some time during this century around the Priest quarters. 


\section{Lead Glazed Wares}

\section{Sandy Paste Earthenwares}

Sherds from bowls and jars of wheel made Sandy Paste earthenwares make up the largest group of lead glazed wares from this site. The glaze is very pale green or yellow over an orange colored paste, and covers the interior and spills over the rim onto the outside (Fox 1974:56). Vessels range from five to eleven $\mathrm{mm}$ in thickness. There are great variations of thickness, but all vessels have a similar sandy paste containing numerous black and a few red inclusions. Decorations consist of green rim bands and splotches of green in no particular pattern. (Figure 22e and f)

\section{Galera Ware}

Sherds with a fine-textured red paste under a clear lead glaze give an orange appearance. The vessels are primarily chocolateros and bean pots with thin (3 to $4 \mathrm{~mm}$ thick) walls. They are decorated with thin brown lines and occasional cream colored dots. The chocolateros have brown, cream, and green floral decorations on the upper outside portion of the neck (Fox 1974:58). These vessels appear to be molded rather than wheel-made. Schuetz (1969:50) identifies this ware as coming from western Mexico. It is generally called Galera Ware throughout the southwest.

\section{Black Luster Ware}

Sherds with a black lustrous glaze have been identified by Schuetz (1969:52) as Black Luster Ware. Two sherds of this type are in this collection.

\section{Tonalá Polychrome Glazed Ware}

A little-known ceramic type bears a cream enamel decorated with green and red brown designs and covered with a clear lead glaze. Most sherds are in poor condition, with much of the glaze flaked off, making it difficult to identify. It is currently called Tonalá Polychrome Glazed Ware and has been dated by Gerald (1957:173) ca. 1780 to 1830 . A few sherds of this type generally show up in San Antonio mission collections, as in this case.

\section{Tin Glazed Ware}

Tin glazed earthenwares are covered with a clear lead glaze to which tin has been added in order to create a background for colored enamel decoration. The patterns and color combinations changed from time to time, which makes this type of ceramic particularly useful for dating sites and deposits with them. The tin glazed wares made in Mexico are generally referred to as majolica.

\section{Undecorated}

Undecorated sherds can represent either totally undecorated vessels which were made throughout the eighteenth century (Lister and Lister 1974:30). They could also be from undecorated areas on otherwise decorated vessels. By far the largest proportion of the tin glazed sherds are undecorated in this collection.

\section{San Agustín Blue on White}

This type was first identified by Goggin (1968:189) and dated by him from 1700 to 1730 . More recently, it has become apparent that this type continued into the mid-eighteenth century and perhaps a bit later. The design has floral designs in dark and light blue with occasional accents in black and with large blue loops on the back of the vessels. The few examples in this collection do not seem to have indications of blue on the reverse, but are too small to be sure.

Blue and White is used here as a category to include all sherds with only traces of blue decoration. They are too small or the blue decoration is too fragmentary to further identify a type. There are a number of different eighteenth century styles of decoration that these sherds might represent.

\section{Huejotzingo}

Huejotzingo is the name used for a ceramic type with a single band of color at the rim. This type was made throughout the eighteenth century (Goggin 1968:195). 


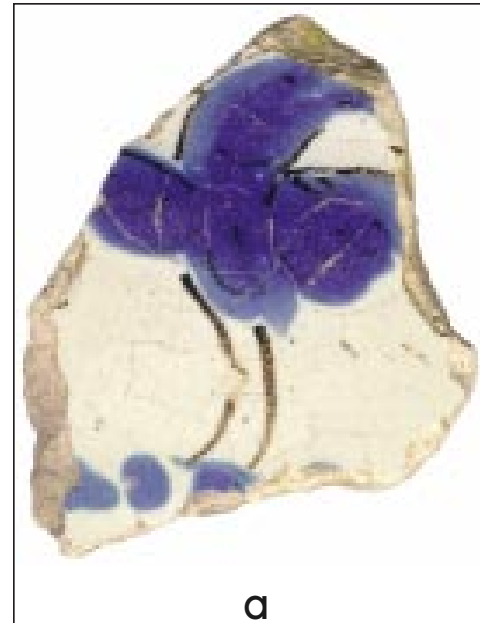

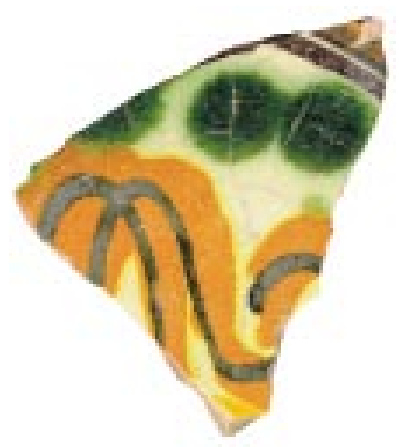

b

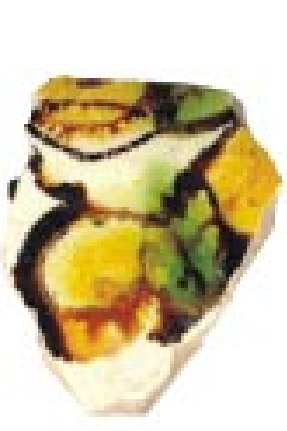

C

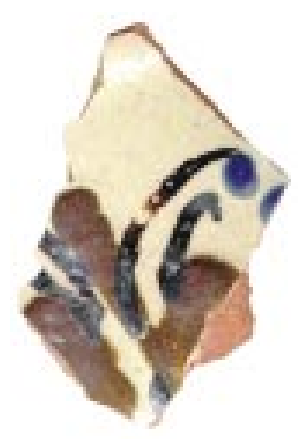

d

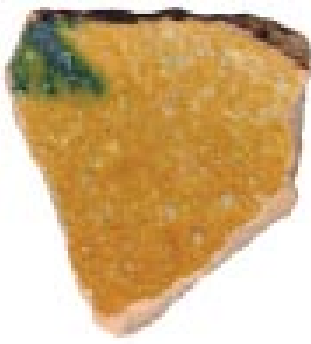

e

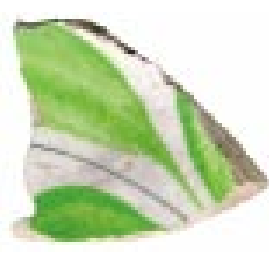

h

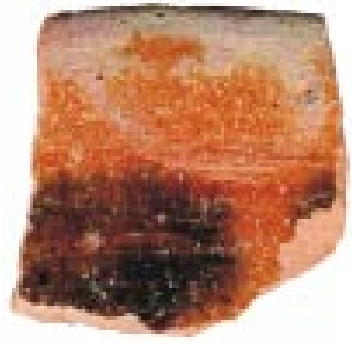

f

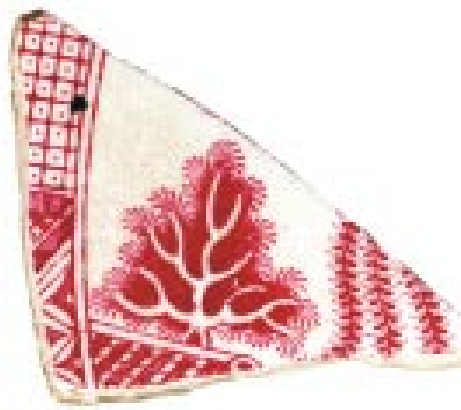

g a. San Elizario tin glaze

b. Monterey Polychrome tin glaze

c. Unidentified tin glaze

d. Brown, black, and blue tin glaze

e. Sandy paste lead glaze

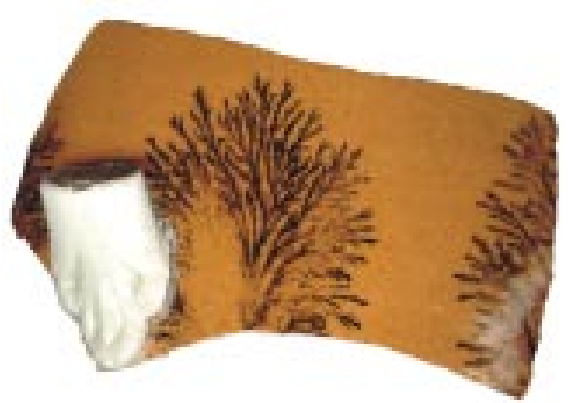

j

Figure 22a-j. Unique Ceramics.

f. Sandy paste lead glaze

g. Transfer on whiteware

h. Hand painted whiteware

i. Transfer on whiteware

j. Mocha design on whiteware 


\section{San Elizario}

This type consists of a pattern with a blue band just inside the rim outlined with brown/black lines, from which are suspended blue petals and blue flowers accented with black. A central long-legged bird is also accented with brown/black. (Figure 22a) It was first identified and named by Rex Gerald (1968:45) for the site on which he recognized it.

\section{Thin Brown, Black, and Blue}

This is a descriptive term for a type first recognized by Schuetz at Mission San Juan Capistrano (1969:57). Al though the two sherds of this type in this collection are slightly thicker than those at San Juan, the color combination is much the same consisting of brown and black leaves and stems with blue dots for flowers (Figure 22d).

\section{Monterey Polychrome}

This is the generally accepted name for an orange banded design consisting of green leafy sprays alternating with yellow and orange designs accented with black lines and slashes (Figure 22b) The name was first used by May (Barnes and May 1972:12). It was popular from 1800 to 1830 in California and is one of the best-represented late eighteenth century types at the missions at San Antonio and Goliad.

\section{Puebla Blue on White II}

This is a design found only on cups and bowls of the late eighteenth century. The design consists of thin blue bands occasionally accented by blue dots on the outside of vessels. It was first described and named by Goggin (1968:191).

Unidentified designs are often found among the sherds from Colonial sites. In this case, there was one sherd with a yellow glaze on the outside and white tin glaze on the inside that does not fit into any known category. Two other sherds bear a mustard-colored band below a white rim. Another small sherd has the orange band and brown-bordered ball below that is probably part of a design designated by May (1972) as San Diego, popular from 1770 to 1800 in California. Finally, a medium-sized sherd is decorated with a pattern of pale green and yellow splotches outlined with dark brown lines (Figure 22c). The treatment and color combination suggests that this is a late eighteenth to early nineteenth century type, probably bordered with an orange band.

\section{Guanajuato Polychrome}

The latest-dating tin glazed type in this collection is from Guanajuato, made after 1810 (Lister and Lister 1974:Fig.12). The red paste, cream glaze, and green and brown decoration displayed are typical of this type.

\section{Faience}

Another category of tin glazed ceramic is faience, which was made in France. A few of these French wares are nearly always represented in collections from the missions, no matter where in Texas the sites are located. In this collection, one each of five entirely different patterns is represented.

One sherd with a white background has touches of a pale green and lavender design that reminds one of late nineteenth century decal designs on white ware. However, this sherd has the soft yellow paste typical of faience. Another sherd has traces of purple, blue, and orange designs on a pale blue background. Again the paste is a soft yellow. A third sherd has yellow and brown design traces on a pale gray background on a pale yellow paste. A fourth sherd has a bright blue and red design on a white background over the usual pale yellow paste. The final sherd has a white glaze on one side and a dark chocolate brown on the other and was probably made in Rouen, France.

\section{Whitewares}

The appearance of white-bodied ceramics generally indicates nineteenth century occupation on San Antonio sites. British-made whitewares began to appear in the San Antonio area in any quantity in the early 1830 s. During the first half of the century these ceramics were usually decorated with various bright colors in a number of different techniques such as transfer, hand painting, and slip decoration (Figure 22g-j). After the close of the Civil War, plain, undecorated whitewares became the ceramics of choice. During this period, heavy ironstone wares with little or no decoration over- 
whelmed the market and therefore the ceramics collections from most archaeological sites. Since this portion of the Espada Mission has continued to be occupied up to the present day, a full range of early eighteenth through late nineteenth century ceramics are represented in this collection.

Post-nineteenth century ceramics in the collection include one decal-decorated sherd, nine sherds with green glaze on both sides typical of the first half of the twentieth century, and eight contemporary chinaware coffee cup sherds and six sherds from a relatively recent Hotel Ware plate are also present.

\section{Stoneware}

Stoneware is a dense, kiln-fired ceramic with a white, tan or gray paste. Used primarily for kitchen operations or food storage, immigrant potters brought the stoneware technique into the state from the east coast or from European countries. In order to make the stoneware vessels impervious to liquids and also for ease of cleaning, various glazes were used to seal the surfaces. In this collection stoneware is represented by four salt-glazed sherds from a crock or churn and one fragment from a Bristol-glazed vessel with a blue sponged decoration.

Two sherds of stoneware in the collection are from bottles used to store and ship liquids. One sherd is from a stoneware bottle manufactured in Europe. These usually contained mineral water (Kendrick 1966:73) The other sherd is from a stoneware bottle made in the British Isles to contain ale, stout, or ginger beer. These sherds probably date to the late nineteenth century.

\section{Porcelain}

Porcelain is a vitrified, translucent ceramic. It was not made in the United States until the late nineteenth century. The few porcelain sherds in this collection represent plates and other vessels probably from United States factories. Because it is impervious to liquids, porcelain is also used for parts of electrical and plumbing fixtures. Several sherds in this collection may come from such articles but they are too small to permit proper identification.

\section{Kitchen and Household}

The second highest number of artifacts recovered, are associated with the kitchen and household category. A total of 2,504 items, 26.9 percent of the total $(n=9,302)$, were recorded within this category. Among these were two light bulb bases, one from Unit 7, Level $4(30-40 \mathrm{~cm} \mathrm{bs})$ and the other from Unit 9, Level 1 (0$10 \mathrm{~cm} \mathrm{bs})$. There were two clothespin hinges found in Unit 8. One straight pin was found in Unit 1, Level 3 $(20-30 \mathrm{~cm} \mathrm{bs})$. There also was one half of a tin can with openings punched into the lid from Unit 9, Level $1(0-10 \mathrm{~cm}$ bs). Also from Unit 9, one diner style (i.e., mass-produced) salt or pepper shaker was recovered from Level 3 (20-30 cm bs), the only marks on the shaker were "1 3 " on the base which offered no help in identifying a manufacturer. One large tin can key was found in Unit 15, Level $2(10-20 \mathrm{~cm} \mathrm{bs})$. Similar keys were used in conjunction with canned meats such as ham, corned beef, and Spam (Vaughn 1997: 213). One metal teaspoon was recovered from Unit 9, Level 7 (50-60 cm bs). The spoon was very rusted, revealing no identifying marks.

A total of 256 bottle caps, screw caps, and pull-tabs were recovered. Of the bottle caps in which the marks could be identified, one was a "Coca Cola" cap recovered from Unit 8, Level $2(10-20 \mathrm{~cm}$ bs) with a losing game piece on the inside that was dated to $1982-$ 1985 through the slogan "Coke is it" which appeared on the cap. Another was from a "Spizz" soda bottle, recovered from Unit 13, Level $3(20-30 \mathrm{~cm} \mathrm{bs})$, that could be dated to ca. 1950. The other identifiable soda cap was from a "Fanta" bottle that was found in Unit 16 , Level $3(20-30 \mathrm{~cm} \mathrm{bs})$. The majority of the bottle caps were extremely rusted. Also, one "Purex" screw cap was recovered from Unit 5 in the wall scrapings.

A total of 1,978 glass fragments related to various types of containers were extracted from the site. Of these, only 122 (6 percent of the total) were considered to be diagnostic. The diagnostic glass fragments represent soda bottles, medicine bottles, and decorated glass fragments. Many of the diagnostic fragments are rims and bases from various types of soda bottles. In Unit 7, Level 8 (70-80 cm bs), an almost intact Barq's Root Beer bottle was recovered. The colors used in the writing on the bottle are blue and orange. These colors 
were dropped from use in 1976 when the company was sold and the new owners changed the design to the silver that is still used today (Petretti 1999). Other fragments throughout the site indicate the presence of Fanta, Dr. Pepper, and Coca-Cola bottles. Due to the presence of a maker's mark on the base, we can conclude that the Knox Glass Bottle Co. of Mississippi produced the Fanta bottle. The company existed between 1932 and 1953 in Jackson, Mississippi, but a branch of this company was established in Palestine, Texas in 1941.

One glass fragment recovered from Unit 8, Level 4 seems to be a Mason-type jar. The fragment exhibited "31 1915 ON" embossed on the outer part. Two examples of clear medicine bottles were extracted from the site. One of these is a portion of the base and one side of the bottle with a maker's mark on the base. The mark indicates that the bottle was produced by the Owens-Illinois Glass Company, some time before 1954 (Toulouse 1971). The other medicine bottle example is fully intact and was recovered from Unit 16, Level 2 (10-20 cm bs). The only marks are located on the base, indicating that it is a $2 \frac{1}{2}-\mathrm{fl}$. oz. bottle.

One soda bottle base was recovered from Unit 9, Level $4(30-40 \mathrm{~cm}$ bs) that exhibited an Owens-Illinois Glass Company maker's mark. The mark was utilized between 1929 and 1954, and most likely was produced in their Charleston factory (Toulouse 1971). Another partial soda bottle base was recovered from Unit 9, Level 4 (30-40 cm bs). This base was made of green glass and exhibited an Owen-Illinois Glass Company maker's mark. The mark was from a Duraglas piece that has been manufactured since September 4, 1940 (Toulouse, 1971).

A total of 1,978 undiagnostic glass fragments were recovered throughout the site. Many different colors of glass were present in the fragments recovered from the site. These include 1,273 fragments of clear glass; 252 fragments of green; 212 fragments of brown; 188 fragments of olive; 38 fragments of blue; 9 fragments of amber; 4 fragments of red; one fragment of yellow; and one fragment of milk glass. Beyond stating that amber glass was produced between 1880 and 1930 (Kendrick 1966), nothing more can be determined about the rest of the fragments. A total of 134 lamp glass fragments were recovered from the site. The majority of the fragments were clear, although there were four fragments of blue. These fragments were too small to possess analytical value.

\section{Construction}

A total of 4,633 artifacts associated with building material were recovered from the site. Of this total, $2,209(47.5 \%)$ were window glass fragments. These fragments were found in most levels of the units. Several fragments were from a "frosted" window that contained sunburst designs that distorted the view. The main concentration of window glass is within the first $30 \mathrm{~cm}$ below surface, in Units 13, 15, 11, 14, 4, and 6 . Each of the five walls excavated has one window apiece.

The nails recovered during the course of the project are either cut or wire nails. Of the total $(n=1,169)$, only $136(11.6 \%)$ were cut nails. Between 1790 and 1830 there was a technological transition from handwrought to machine-cut nails (Nelson 1968). There are several categories these nails could be placed in to decipher the date of manufacture, but the cut nails are highly rusted, making it difficult to discern any distinguishing marks. The majority of the cut nails $(n=116)$ were recovered from the upper levels of the units $(0-40 \mathrm{~cm} \mathrm{bs})$. During the $1850 \mathrm{~s}$ a new type of nail was introduced. Wire nails were initially used for smaller projects such as cigar boxes and pocket books. A total of $1,033(88.4 \%)$ wire nails were recovered from all units. During the 1890 s, wire nails began to be the dominant type used in building construction. The presence of wire nails may suggest repairs or alterations made as early as the late-nineteenth century (Nelson 1968). A total of 33 screws were recovered from the area. These screws varied in size and seemed to have been only present in the top levels of the units.

A total of 406 fragments of roofing composition were recovered. These were found in all units and within Levels 1 through $5(0-50 \mathrm{~cm}$ bs $)$. A total of 615 brick and tile fragments were recovered from most units in Levels 1 through 8 (0-80 cm bs). Mortar fragments, 199 pieces, were found in Units 1, 3 through 9, 11, 13 , and 14 in various levels. Four fragments of plaster were recovered from the site, two in Unit 12, Level 6 
(50-60 cm bs) and two in Unit 14, Level $1(0-10 \mathrm{~cm}$ bs). There was also a total of 188 electrical items, including wire, insulator, and contacts, were recovered from most of the units (Levels 1-3, 0-30 cm bs), suggesting periodic disturbances due to building construction.

\section{Clothing and Personal}

A total of 32 clothing and personal items were recovered from the site. These comprised three-tenths of one percent of the total artifacts recovered. One metal buckle was recovered from Unit 14, Level $1(0-10 \mathrm{~cm}$ bs). The buckle is approximately $3 \mathrm{~cm}$ in length and $2.9 \mathrm{~cm}$ in width, and is highly rusted, making identification impossible. A total of eight buttons were recovered from the excavations. One extremely rusted metal button was found in Unit 13, Level $1(0-10 \mathrm{~cm}$ bs). The button was approximately $17 \mathrm{~mm}$ in diameter and lacked any identifying marks. Three examples of shell buttons were recovered from the site. One was a small pink iridescent, 4-holed button. This button was approximately $9 \mathrm{~mm}$ in diameter and was recovered from Unit 7, Level 3 (20-30 cm bs). Another example was half of white, 2-holed shell button, approximately $15 \mathrm{~mm}$ in diameter found in Unit 12 , Level 5 (40-50 cm bs). This button had an incised rim band and looks as though the face was beveled. The other shell button was recovered from Unit A at 30-40 $\mathrm{cm}$ below surface and is iridescent pearl with two holes. The button appears to be machine-made. One example of a bone button appeared in Unit 2, Level 3 (20-30 cm bs). Only a fragment was recovered but it could have had a diameter of $12 \mathrm{~mm}$. Three examples of modern, synthetic material buttons were recovered. One is a two-holed, white, opaque button approximately $14 \mathrm{~mm}$ in diameter that was recovered from Unit 9, Level 5 (40-50 cm bs). This button has an incised rim band and a dome-shaped face. Another button which was found in Unit 3, Level 5 (45-55 cm bs) was a four-holed, iridescent, semi-clear button, and was approximately $9.5 \mathrm{~mm}$ in diameter. The last example was a four-holed, white button with a diameter of $9 \mathrm{~mm}$ which was recovered from Unit 6, Level 4 (30-40 cm bs).
There were three instances of beads recovered from this site. One is half of a burnt-orange glass bead approximately $16 \mathrm{~mm}$ in dimension. This bead was recovered from Unit 8, Level $5(40-50 \mathrm{~cm} \mathrm{bs})$, in an area of periodic disturbance due to building construction. The other beads recovered were black in color and had a ring shape. They are approximately $11 \mathrm{~mm}$ in diameter and $2 \mathrm{~mm}$ in width. One of these was recovered from Unit 7, Level 6 (50-60 cm bs), while the other was from an area of less disturbance, in Unit 4, Level $2(10-20 \mathrm{~cm} \mathrm{bs})$.

Two pieces of fabric were recovered. One fragment came from Unit 6, Level $1(0-10 \mathrm{~cm} \mathrm{bs})$, and is a piece of burlap similar to that of potato sacs. The other, from Unit 13, Level $1(0-10 \mathrm{~cm} \mathrm{bs})$, is a piece of crinoline tulle similar to that found in women's petticoats. One small metal eyelet, such as those used on shoes, was found in Unit 12, Level 1 (0-10 cm bs). Three fragments, of what appear to be from shoe sole, were also found. Two from Unit 12, Level $1(0-10 \mathrm{~cm} \mathrm{bs})$ appear to be soles of shoe heels, and one of these could possibly be from a woman's pump. The third was recovered from Unit 16, Level $2(10-20 \mathrm{~cm}$ bs) and may also be part of a heel. A fragment of a translucent yellow comb was recovered from Unit 9, Level 2 (10$20 \mathrm{~cm} \mathrm{bs})$.

A total of eight coins were found throughout the site. Three of these coins are worn to the point that they cannot be identified and were recovered from Unit 2, Level 3 (20-30 cm bs), Unit 16, Level $2(10-20 \mathrm{~cm}$ bs), and Unit 8, Level 3 (20-30 cm bs). Of the remaining five, two are nickels and three are pennies. Two of the pennies' dates cannot be deciphered, but one found in Unit 15, Level 4 (30-40 cm bs) may have been minted either before 1943 or after 1962 due to the amount of copper rust (Yeoman 1967). The other penny whose date could not be deciphered was found in Unit 6, Level $2(10-20 \mathrm{~cm}$ bs). The third penny was recovered from Unit 5, Level $3(20-30 \mathrm{~cm} \mathrm{bs})$ and struck in 1946 at the San Francisco mint. Of the two nickels, only one could be dated. The undated nickel was found in Unit 6, Level $2(10-20 \mathrm{~cm}$ bs). The dated nickel was recovered from Unit 12, Level 2 (10-20 $\mathrm{cm}$ bs) and struck in 1946 at the Philadelphia mint. 


\section{Activities}

A total of three marbles were found throughout the site. Two are machine-made glass marbles dating between 1940 and 1950. One of these, made of an opaque milk glass with a red swirl, was recovered from Unit 8, Level $3(20-30 \mathrm{~cm} \mathrm{bs})$ and is $17 \mathrm{~mm}$ in diameter. The other is a transparent green glass swirl-marble, found in Unit 3, Level $3(20-30 \mathrm{~cm} \mathrm{bs})$, that is $15 \mathrm{~mm}$ in diameter. The third is an early handmade marble of transparent clear glass with a multicolored swirl and is approximately $17 \mathrm{~mm}$ in diameter and out-of-round. This is a German, handmade marble manufactured sometime between 1850 and 1880 (Zapata 1995). This marble was recovered from Unit 6, Level $5(40-50 \mathrm{~cm}$ bs). One gray plastic fragment of a toy car was recovered from Unit 9, Level 4 (30-40 cm bs). It lacks any evidence of a maker's mark, but can be identified as the right fender and side of the toy car. The fragment has part of the headlight remaining and a hole through the fender where the wheel axle had once been. Three pencil fragments were found, and all three are the upper, metal eraser-head portion of the pencil. One came from Unit 6, Level $2(10-20 \mathrm{~cm}$ bs $)$ and still had a section of the yellow pencil wood and lead. The other fragments came from Unit 15, Level $3(20-30 \mathrm{~cm}$ bs) and Unit 7, Level 5 (40-50 cm bs).

Two chipped sandstone discs were found and were identified as gaming pieces called cuatros. These type of gaming pieces are still used by the Tarahumara Indians of Northern Mexico. The goal of the game is to land the cuatros in a hole, from a predetermined distance (Schuetz 1969). One of these was recovered from Unit 13, Level 4 (30-40 cm bs) and has a diameter of $59 \mathrm{~mm}$. The other disc came from Unit 14, Level 1 (0$10 \mathrm{~cm} \mathrm{bs}$ ) and has a diameter of $64 \mathrm{~mm}$. A die was recovered from Unit 8 , Level $8(70-80 \mathrm{~cm} \mathrm{bs})$. It is made of a red synthetic material that is slightly translucent, and contains only twos and sixes. This gaming piece measures $11 \mathrm{~mm}$ in length per side.

\section{Arms}

Three examples of casings were recovered at Mission Espada. One was found in Unit 2, Level $1(0-10 \mathrm{~cm}$ bs) and was identified as a 25 -caliber cartridge. This cartridge was developed for the F.D. Bliss cartridge revolver, a gun that was an infringement of the Smith and Wesson patent, and dates to ca. 1863 (Logan 1959). Another was found in Unit 8, Level 2 (10-20 $\mathrm{cm}$ bs) and may be a 22 caliber shot cartridge, manufactured by Rem-UMC. The third casing recovered came from Unit 4, Level 1 (0-10 cm bs) and was identified as a 12 gauge shot cartridge with "Remington Express" embossed on the bottom.

\section{Barn and Workshop}

A total of 122 artifacts (1.3\% of the total) relating to barn and workshop were recovered. This includes 74 fragments of wire, either barb, chicken, fence or electrical. There were also five fence staples of assorted sizes. Two hooks were located, one from Unit 8, Level $7(60-70 \mathrm{~cm} \mathrm{bs})$ and the other from Unit 9, Level 3 (20-30 cm bs). In Unit 9, Level 4 (30-40 cm bs) a part of a small chain link (fence) was recovered. A piece of braided twine was recovered from Unit 4, Level 1 $(0-10 \mathrm{~cm} \mathrm{bs})$, and may be a recent deposit related to recent disturbances. A thumbtack was recovered from Unit 5, Level $1(0-10 \mathrm{~cm}$ bs). A pop rivet, used in aluminum riveting, was recovered from Unit 3, Level 2 (10-20 cm bs).

One-half of a horseshoe was recovered from Unit 5, Level $2(10-20 \mathrm{~cm} \mathrm{bs})$. This was also highly rusted, but the shoe retained four horseshoe nails. Judging by the shape of the shoe, it belonged to the hindquarter of a medium sized horse. The reinforcing bar of the shoe was very worn; meaning any possible maker's mark was abraded away. One heavily rusted pulley wheel was recovered from Unit 8, Level $4(30-40 \mathrm{~cm}$ bs). The pulley is $4.5 \mathrm{~cm}$ in diameter and $1 \mathrm{~cm}$ in width. It has five spokes and only one side is fully intact. An iron spike, a possible chisel, was recovered from Unit B, Level 8 (70-80 cm bs).

\section{Metal Fragments}

A total of 830 scrap metal fragments were recovered from the site. These fragments, composed of iron, copper, and aluminum, constitute this category, with iron scraps being predominant. 
The majority of the iron scraps tended to be thin and rusted, and may be remnants of tin cans. Such fragments are typically found in nineteenth century sites, and could also indicate disturbance of the deposits (Tomka and Fox 1998).

\section{Miscellaneous}

A total of 191 artifacts are included in the miscellaneous category. Approximately 64 plastic fragments were found throughout the units, and mainly in Levels 1 through $5(0-50 \mathrm{~cm} \mathrm{bs})$, although a few pieces were found in Unit 7, Level 8 (70-80 cm bs). Several uncharred pits and seeds were found at the site, in Unit 1, Level $2(10-20 \mathrm{~cm}$ bs) and in Units A and B, Level 6 (40-60 cm bs). Several fragments of coal/slag were found in several units at different levels. A total of 99 artifacts were labeled as "other", and most of these were fragments of aluminum foil.

\section{Vertebrate Faunal Remains}

\author{
Barbara A. Meissner
}

\section{Methods}

A total of 6,485 vertebrate faunal remains, weighing $12,542.15 \mathrm{~g}$, was recovered during the project. The bone was identified to the most specific taxon possible using the comparative collection at CAR, as well as several reference texts (Balkwill and Cumbaa 1992; Boessneck 1970; Cohen and Serjeantson 1996; Gilbert 1990; Hildebrand 1955; Hillson 1986; Olsen 1960, 1964, 1968; Schmid 1972; Sobolik and Steele 1996). Identifications were conservative; i.e., bone, which appeared to be cow-sized, was not identified as Bos taurus unless it could be differentiated from Bison and Equus species. All bone was weighed. Evidence of exposure to heat was noted on all bone. Element, portion of element, side, evidence of immaturity, butcher marks, and pathologies were noted on bone identified to the order taxonomic level. When bone could be identified only to class (e.g. mammal, bird, etc.) an estimate of the size of the animal was made when possible. After the analysis the bone was bagged by unit and level. Bone identified to at least the order taxonomic level was bagged separately and included in the unitlevel bags.

Three measures of relative abundance were used to estimate the importance of all species to the meat diet as represented by this collection: Number of Identified Specimens (NISP), Minimum Number of Individuals (MNI), and bone weight. NISP is the count of specimens that have been identified to at least the genus taxonomic level. It's use as a measure of relative abundance is problematic (Grayson 1984:20-24; Reitz and Wing 1999:191-192). As Reitz and Wing (1999:192) have remarked: "By using [NISP] as a measure of abundance, the analyst assumes cultural and non-cultural fragmentation is uniform, recovery rates are constant for each taxon, and all taxa have an equal opportunity to be counted." Of course, none of those assumptions should, in fact, be made. NISP cannot differentiate between 11 fragments from 11 different cows and 11 fragments of a single cow bone. Reliance on NISP alone will distort the estimate of relative abundance in favor of small animals and 
animals with parts that are more readily identifiable in fragmentary form. For instance, the anterior diaphysis of the metatarsal of the white-tailed deer (Odocoileus virginianus) is so distinctive that it can readily be identified even in very small fragments. A small fragment of the same element in other small artiodactyls, such as goat or sheep, is not so distinctive and could not be identified to genus. This will lead to the "analytical absence" (Lyman and O'Brien 1987) of fragments of artiodactyl metatarsal that are not from deer, and make importance of deer in the collection, compared to sheep and goats, seem larger than it really was.

Minimum Number of Individuals (MNI) is a derived measure commonly used to get around some of the problems of NISP. MNI is the minimum number of animals of each species that must have been present to account for the elements identified for that species. This is determined by dividing paired elements (or portions of elements such as proximal or distal ends) into right and left side, and then finding the most abundant such element. Estimated age of the animals (at least immature vs. mature) is often considered in the analysis. MNI can, if properly calculated, be a useful counterpoint to NISP. However, MNI also has problems as a measure of relative abundance. Grayson (1984: 29-49) has pointed out that MNI is extremely sensitive to the way in which the analyst aggregates the data. MNI counts can be made to vary a great deal by changing how the analyst groups the data, for instance, by unit/level, by complete unit, by natural level, by the entire site, etc. (see Grayson 1984:34-49). The more inclusive the grouping, the more the data are reduced. In the particular case of this project, the analyst had a choice of aggregating the collection by unit, by level, by adjacent wall, or grouping the entire collection. The latter course was chosen as the least likely to resulted in grossly distorted estimates, especially of the less common taxa.

Bone weight can also, with caution, be used as a measure of relative abundance. Bone weight is, in general, a better indicator of relative dietary importance (as opposed to relative abundance) than NISP or MNI, but this measure must not be used exclusively. In general, larger bones carry more meat, but the relationship is not linear (Reitz and Wing 1999:222-231), varies among different taxa, and there is considerable variation from one part of the animal to another (e.g., lower legs of cattle are dense, heavy bones but carry relatively little meat compared to other bones of the body). Comparing taxa of different classes can be problematic. For instance, because most of the body weight of fish is carried by the water, their bones are a much smaller percentage of total body weight than is seen in land animals. As a result, the bone weight of fish seriously underestimates the relative importance to the diet when compared with mammals.

Using bone weight as an assessment of dietary importance also suffers from the necessary assumption that all taphonomic factors, which affect bone weight (such as leaching, mineralization, or encrustation), have affected all bone in the collection uniformly. Bone weight tends to emphasize the importance of larger, heavier animals, and due to this, tends to counterbalance the tendency of NISP to emphasize smaller animals.

Each analytic method discussed above is subject to a number of biases (Reitz and Wing 1999:200). Consideration must be given to the fact that badly fragmented bone is usually unidentifiable, and is thus "analytically absent". Small bones are more likely to be rendered unidentifiable by non-cultural taphonomic factors (Von Endt and Ortner 1984), while large bones, especially those of such animals as cattle, may be more likely to be processed to extract bone grease, leaving the majority of the bone unidentifiable. The degree to which any of these factors has affected the collection cannot usually be assessed. Used together, however, NISP, MNI, and bone weight can provide a better picture of the relative importance of each species to the diet than either can provide when used alone.

\section{Analysis}

A list of identified taxa is shown in Table 5, with counts and weights. A complete, provenienced list of all data recovered from the bone is in Appendix $\mathrm{C}$. The bone was in unusually good condition, with little evidence of damage from atmospheric or chemical weathering, however 81 percent of the bone could be identified only as mammalian. Only 388 bones ( 6 percent) could be identified to the genus taxonomic level. The percent of animals identified to the genus level is somewhat higher in this collection than is seen in many 
Colonial period sites in San Antonio. There is considerable variation in the degree of fragmentation of bone from Colonial sites (see Meissner 1999a:45). Factors that can affect the degree of fragmentation include bone processing behaviors, location of bone (i.e., whether it was in a protected area), and whether and how often it had been disturbed before excavation.

\section{Taxa Identified}

The list of bone specimens identified to at least the genus taxonomic level in the test units is listed in Table 6, with bone weights and MNI. A total of twentysix genera were identified. Catfish (Ictalurus sp.) is the most commonly identified bone, constituting

Table 5. Taxon List

\begin{tabular}{|c|c|c|c|c|}
\hline Taxa & Common Name & Count & Weight (g) & Notes \\
\hline \multicolumn{4}{|c|}{ Mammals } & \\
\hline Artiodactyl & Deer, sheep, goats & 317 & $1,353.09$ & Very similar species \\
\hline Bos taurus & Cattle & 18 & $1,050.70$ & $\begin{array}{l}\text { Usually the most common species in Spanish Colonial } \\
\text { sites in Texas }\end{array}$ \\
\hline Bovinae & Cattle or bison & 63 & $1,289.27$ & Difficult to differentiate \\
\hline Canis sp. & Dog, wolf, or coyote & 2 & 6.56 & \\
\hline Capra hircus & Domestic goat & 16 & 135.15 & \\
\hline Capra/Ovis & Goat or sheep & 61 & 488.47 & Sometimes difficult to differentiate \\
\hline Carnivora & Carnivore & 1 & 3.55 & Raccoon-sized \\
\hline Chiroptera & Bats & 1 & 0.03 & $\begin{array}{l}11 \text { species of bats are common in area today (Davis } \\
\text { Schmidly 1994:44-81) }\end{array}$ \\
\hline Didelphis virginiana & Opossum & 1 & 0.69 & \\
\hline Equus sp. & Horse family & 3 & 66.10 & \\
\hline Felis domesticus & Domestic cat & 1 & 1.83 & \\
\hline Neotoma sp. & Woodrats & 1 & 0.20 & \\
\hline Odocoileus virginianus & White-tailed deer & 21 & 148.60 & \\
\hline Ovis aries & Domestic sheep & 67 & 784.14 & \\
\hline Pecari tajacu & Javelina, collared peccary & 1 & 0.67 & \\
\hline Procyon lotor & Raccoon & 1 & 0.11 & \\
\hline Rodentia & Rodents & 9 & 1.81 & \\
\hline Sciurus sp. & Tree squirrels & 1 & 0.29 & Probably S. niger (Eastern Fox Squirrel) \\
\hline Sus scrofa & Domestic pig & 10 & 49.32 & \\
\hline Sylvilagus sp. & Cottontail rabbit & 8 & 1.74 & $\begin{array}{l}\text { Ranges of } 3 \text { very similar species overlap (S. floridanus, } \\
\text { S. audubonii, S. aquaticus) }\end{array}$ \\
\hline Mammal--very small & Mice, rat-sized & 2 & 0.13 & \\
\hline Mammal--small & Rabbit-sized & 10 & 5.14 & \\
\hline Mammal--medium & Dog-sized & 24 & 22.88 & \\
\hline Mammal--large & Deer, sheep-sized & 379 & $1,132.80$ & \\
\hline Mammal--very large & Cattle, bison, horse-sized & 385 & $2,597.71$ & \\
\hline Mammal & Size indeterminate & 4,434 & $3,058.11$ & \\
\hline & Total Mammals & 5,837 & $12,199.09$ & \\
\hline
\end{tabular}


Table 5, continued...

\begin{tabular}{|c|c|c|c|c|}
\hline Taxa & Common Name & Count & Weight (g) & Notes \\
\hline \multicolumn{5}{|l|}{ Aves } \\
\hline Anas sp. & Ducks & 2 & 0.93 & $\begin{array}{l}8 \text { species are seen in area today (Rappole and } \\
\text { Blacklock 1994:38-45) }\end{array}$ \\
\hline Branta canadensis & Canadian goose & 3 & 4.16 & \\
\hline Callipepla/Colinus & Scaled quail or bob-white & 1 & 0.13 & $\begin{array}{l}\text { These two species will hybridize (Rappole and } \\
\text { Blacklock 1994:72) }\end{array}$ \\
\hline Columbidae & Doves, pigeons & 6 & 1.54 & $\begin{array}{l}\text { Probably mourning dove (Zenaida macroura) but } \\
\text { possibly the introduced common pigeon (Columbia } \\
\text { livia) }\end{array}$ \\
\hline Corvidae & Jays, crows, ravens & 2 & 0.51 & Probably a blue jay (Cyanocitta cristata) \\
\hline Gallus domesticus & Chicken & 42 & 30.70 & $\begin{array}{l}\text { Usually present only in small numbers in Colonial } \\
\text { sites. }\end{array}$ \\
\hline Meleagris gallopavo & Turkey & 7 & 30.76 & $\begin{array}{l}\text { These are assumed to be wild, though it is possible } \\
\text { they were domestic. }\end{array}$ \\
\hline Turdus migratorius & Robin & 8 & 1.04 & \\
\hline Aves--small & Mockingbird-sized & 3 & 0.07 & \\
\hline Aves--medium & Pigeon-sized & 2 & 0.20 & \\
\hline Aves--large & Chicken-sized & 30 & 17.54 & \\
\hline Aves--very large & Turkey, hawk-sized & 10 & 12.23 & \\
\hline \multirow[t]{2}{*}{ Aves } & Size indeterminate & 123 & 41.85 & \\
\hline & Total Birds & 239 & 141.66 & \\
\hline \multicolumn{5}{|c|}{ Reptiles } \\
\hline Alligator mississippiensis & Alligator & 1 & 7.90 & Often seen in Colonial site in San Antonio \\
\hline Chelydra serpentina & Snapping turtle & 8 & 10.91 & \\
\hline Trionyx sp. & Softshelled turtles & 4 & 8.13 & \\
\hline \multirow[t]{2}{*}{ Testudinata } & Turtles & 1 & 0.46 & \\
\hline & Total Reptiles & 14 & 27.40 & \\
\hline \multicolumn{5}{|l|}{ Amphibia } \\
\hline \multirow[t]{2}{*}{ Rana sp. } & & 11 & 0.60 & $\begin{array}{l}\text { Probably bullfrog (R.catesbeiana) or Rio Grande } \\
\text { leopard frog }(R \text {. berlandieri) }\end{array}$ \\
\hline & Total Amphibians & 11 & 0.60 & \\
\hline \multicolumn{5}{|c|}{ Boney Fishes } \\
\hline Ictalurus sp. & Catfish & 89 & 41.84 & \\
\hline Lepisosteus sp. & Gars & 1 & 0.31 & $\begin{array}{l}\text { Probably Short-nosed (L. platostomas) or Long-nosed } \\
\text { (L. osseus) gar. }\end{array}$ \\
\hline Pylodictus olivaris & Bullhead catfish & 61 & 48.23 & \\
\hline \multirow[t]{2}{*}{ Osteichthyes } & Unidentified fish & 171 & 64.58 & \\
\hline & Total Fishes & 322 & 154.96 & \\
\hline Vertebrata & Unidentified bone & 62 & 18.44 & \\
\hline & Overall Totals & 6,485 & $12,542.15$ & \\
\hline
\end{tabular}


22.9 percent of the total NISP. Together with other identified fish, especially the flathead catfish (Pylodictus olivaris), they represent 38.9 percent of the NISP. Sheep was the next most common taxa (Table 6), with 17.3 percent of the NISP. Together, goat, sheep, and pig were 24 percent of the total. Chicken was also quite common, with 10.8 percent of the NISP. Cattle were only 4.6 percent of the NISP. Whitetail deer and cottontail rabbit were the only wild mammals with more than 1 percent of identified bones. All wild mammals commonly hunted for food (including deer, rabbit, raccoon, opossum, and javelina) taken together were only 8.5 percent of the total. Only 12 turtle bones were identified, totaling 3.1 percent of the NISP.

As discussed in the Methods section however, NISP gives a somewhat false impression of the importance of species with smaller body weight. Table 7, which shows the percentage of total NISP weight for each of the categories listed above, shows that cattle have the highest percent of bone weight, even though they were only 4.7 percent of the NISP.

Table 6. Bone Identified to the Genus Taxonomic Level

\begin{tabular}{|c|c|c|c|c|c|}
\hline Genus & Count & $\%$ & Weight (g) & $\%$ & MNI \\
\hline \multicolumn{6}{|l|}{ Mammalia } \\
\hline Bos & 18 & $4.6 \%$ & $1,050.70$ & $43.2 \%$ & 1 \\
\hline Canis & 2 & $0.5 \%$ & 6.56 & $0.3 \%$ & 1 \\
\hline Capra & 16 & $4.1 \%$ & 135.15 & $5.6 \%$ & 2 \\
\hline Didelphis & 1 & $0.3 \%$ & 0.69 & $0.0 \%$ & 1 \\
\hline Equus & 3 & $0.8 \%$ & 66.10 & $2.7 \%$ & 1 \\
\hline Felis & 1 & $0.3 \%$ & 1.83 & $0.1 \%$ & 1 \\
\hline Neotoma & 1 & $0.3 \%$ & 0.20 & $0.0 \%$ & 1 \\
\hline Odocoileus & 21 & $5.4 \%$ & 148.60 & $6.1 \%$ & 2 \\
\hline Ovis & 67 & $17.3 \%$ & 784.14 & $32.3 \%$ & 4 \\
\hline Pecari & 1 & $0.3 \%$ & 0.67 & $0.0 \%$ & 1 \\
\hline Procyon & 1 & $0.3 \%$ & 0.11 & $0.0 \%$ & 1 \\
\hline Sciurus & 1 & $0.3 \%$ & 0.29 & $0.0 \%$ & 1 \\
\hline Sus & 10 & $2.6 \%$ & 49.32 & $2.0 \%$ & 1 \\
\hline Sylvilagus & 8 & $2.1 \%$ & 1.74 & $0.1 \%$ & 1 \\
\hline Total Mammals & 151 & $38.9 \%$ & $2,246.10$ & $92.4 \%$ & 19 \\
\hline \multicolumn{6}{|l|}{ Aves } \\
\hline Anas & 2 & $0.5 \%$ & 0.93 & $0.0 \%$ & 1 \\
\hline Branta & 3 & $0.8 \%$ & 4.16 & $0.2 \%$ & 1 \\
\hline Gallus & 42 & $10.8 \%$ & 30.70 & $1.3 \%$ & 3 \\
\hline Meleagris & 7 & $1.8 \%$ & 30.76 & $1.3 \%$ & 1 \\
\hline Turdus & 8 & $2.1 \%$ & 1.04 & $0.0 \%$ & 2 \\
\hline Total Birds & 62 & $16.0 \%$ & 67.59 & $2.8 \%$ & 8 \\
\hline \multicolumn{6}{|l|}{ Reptilia } \\
\hline Alligator & 1 & $0.3 \%$ & 7.90 & $0.3 \%$ & 1 \\
\hline Chelydra & 8 & $2.1 \%$ & 10.91 & $0.4 \%$ & 1 \\
\hline Trionyx & 4 & $1.0 \%$ & 8.13 & $0.3 \%$ & 1 \\
\hline Total Reptiles & 13 & $3.4 \%$ & 26.94 & $1.1 \%$ & 3 \\
\hline \multicolumn{6}{|l|}{ Amphibia } \\
\hline Rana & 11 & $2.8 \%$ & 0.60 & $0.0 \%$ & 2 \\
\hline Total Amphibians & 11 & $2.8 \%$ & 0.60 & $0.0 \%$ & 2 \\
\hline \multicolumn{6}{|l|}{ Osteichthyes } \\
\hline Ictalurus & 89 & $22.9 \%$ & 41.55 & $1.7 \%$ & 3 \\
\hline Lepisosteus & 1 & $0.3 \%$ & 0.31 & $0.0 \%$ & 1 \\
\hline Pylodictus & 61 & $15.7 \%$ & 48.23 & $2.0 \%$ & 3 \\
\hline Total Fishes & 151 & $38.9 \%$ & 90.09 & $3.7 \%$ & 7 \\
\hline NISP & 388 & $100.0 \%$ & $2,431.32$ & $100.0 \%$ & 39 \\
\hline
\end{tabular}


By comparing the ranking of the identified genera by each of the criteria used in Table 6, we can avoid some of the biases inherent in each. Table 8 shows the ranking of each genus with more than 3 percent of the total of NISP and bone weight, and all with an MNI greater than 1. Comparing the three lists, we can see that cattle have the highest ranking by weight, with sheep second. Sheep are also ranked second by NISP and first by MNI. The three ways of assessing relative abundance, taken together, point to cattle and sheep as being the most important components of the diet expressed in this collection. Catfish and chicken were also important. Goats and deer were eaten to a lesser extent.

Table 7. Percent of Total NISP Bone Weight for Selected Taxa

\begin{tabular}{|l|c|}
\hline \multicolumn{1}{|c|}{ Taxa Category } & $\begin{array}{c}\text { Percent of Total } \\
\text { NISP Weight }\end{array}$ \\
\hline Cattle & $43.2 \%$ \\
\hline Goats, sheep, and pigs & $39.8 \%$ \\
\hline $\begin{array}{l}\text { Wild mammals hunted for } \\
\text { food }\end{array}$ & $6.3 \%$ \\
\hline Chicken & $1.3 \%$ \\
Fish & $3.7 \%$ \\
\hline Turtles & $0.7 \%$
\end{tabular}

Table 8 . Highest Ranking Genera by NISP, MNI, and Bone Weight

\begin{tabular}{|c|c|c|}
\hline NISP ranking & Bone weight ranking & MNI Ranking \\
\hline$(>3 \%$ of total $)$ & $(>3 \%$ of total $)$ & $(\mathrm{MNI}>1)$ \\
\hline 1 Catfish & 1 Cattle & 1 Sheep \\
\hline 2 Sheep & 2 Sheep & \multirow{3}{*}{$\begin{array}{l}2 \text { Chicken } \\
\text { Catfish } \\
\text { Flathead catfish }\end{array}$} \\
\hline 3 Flathead catfish & 3 Deer & \\
\hline 4 Chicken & 4 Goats & \\
\hline 5 Deer & & \multirow{4}{*}{$\begin{array}{l}3 \text { Goats } \\
\text { Deer } \\
\text { Frogs } \\
\text { Robins* }\end{array}$} \\
\hline 6 Cattle & & \\
\hline 7 Goats & & \\
\hline & & \\
\hline
\end{tabular}

* May not have been food.

\section{Comparison Across Project Area}

We can divide the entire project area into three areas: units associated with Walls 1 and 2 (A, B, 7-10, 13, and 15-16); units associated with Walls 3 and 4 (1-3, 11-12, and 14) and units associated with Wall 5 (4-6). Table 9 shows the NISP of the categories shown in Table 7, divided by these areas. The area associated with Walls 3 and 4 clearly has the most identified bone, with almost 79 percent of the total identified bone.

In both the units associated with Walls 1 and 2 and with Walls 3 and 4, the ranking of the categories is roughly the same, although the units associated with Walls 1 and 2 have more chicken and less sheep, goats, and pigs than the units associated with Walls 3 and 4 (Table 9). The units associated with Wall 5 appear to be somewhat different, as the NISP in these units is dominated by wild animals. Of all the identified wild mammals commonly hunted for food, 50.0 percent $(n=16)$ were found in units along Wall 5. This may merely be a result of the much more limited testing along Wall 5, resulting in a smaller sample size.

\section{Butchering}

Butchering marks were recorded only on bone that was identified to at least the order taxonomic level, with one exception. All saw marks on bones were recorded. This was considered important because sawing bone is a significant temporal indicator. Although we do not know exactly when bone sawing became the normal method of butchery in San Antonio, we do know that sawed bone is never seen in purely Colonial contexts in the San Antonio missions (for instance, no sawed bone was recovered from a well-sealed Colonial period bone bed outside the west wall of Mission San Antonio de Valero [see Meissner 1999b]). It is likely that sawing was introduced by professional butchers at some point in the nineteenth century and was not used in the "home butchering" of the mission inhabitants. Butcher marks were observed on 212 bones. Table 10 lists the butcher mark types and the number of bones displaying these marks by taxon.

Only 10 bones in the collection $(0.2$ percent of the total) showed evidence of being sawed. Of these, the 
Table 9. NISP in 6 Categories, by Area

\begin{tabular}{|c|c|c|c|c|c|c|}
\hline & \multicolumn{2}{|c|}{$\begin{array}{l}\text { Walls } 1 \& 2 \\
(\mathrm{NISP}=53)\end{array}$} & \multicolumn{2}{|c|}{$\begin{array}{l}\text { Walls } 3 \text { \& } 4 \\
(\mathrm{NISP}=304)\end{array}$} & \multicolumn{2}{|c|}{$\begin{array}{c}\text { Wall } 5 \\
(\mathrm{NISP}=31)\end{array}$} \\
\hline Categories & \# & $\%$ of NISP & \# & $\%$ of NISP & \# & $\%$ of NISP \\
\hline Cattle & 3 & $5.7 \%$ & 14 & $4.6 \%$ & 1 & $3.2 \%$ \\
\hline $\begin{array}{l}\text { Goats, sheep, } \\
\text { and pigs }\end{array}$ & 8 & $15.1 \%$ & 85 & $28.0 \%$ & 1 & $3.2 \%$ \\
\hline $\begin{array}{l}\text { Wild mammals } \\
\text { hunted for food }\end{array}$ & 4 & $7.5 \%$ & 12 & $3.9 \%$ & 16 & $51.6 \%$ \\
\hline Chicken & 12 & $22.6 \%$ & 28 & $9.2 \%$ & $\underline{2}$ & $6.5 \%$ \\
\hline Fish & 18 & $34.0 \%$ & 125 & $41.1 \%$ & 8 & $25.8 \%$ \\
\hline Turtles & 1 & $1.9 \%$ & 9 & $3.0 \%$ & 2 & $6.5 \%$ \\
\hline $\begin{array}{r}\text { Total in } \\
\text { categories }\end{array}$ & 46 & $86.8 \%$ & 273 & $89.8 \%$ & 30 & $96.8 \%$ \\
\hline
\end{tabular}

Table 10. Butchering Mark Types and Counts

\begin{tabular}{|c|c|c|c|c|c|}
\hline Taxon & Saw Cut & $\begin{array}{c}\text { Cut } \\
\text { (superficial) }\end{array}$ & $\begin{array}{l}\text { Chop } \\
\text { (deep) }\end{array}$ & $\begin{array}{c}\text { Impact } \\
\text { scar }\end{array}$ & Total* \\
\hline Artiodactyla & & 2 & 107 & 12 & 121 \\
\hline Bos & & 1 & 4 & 3 & 8 \\
\hline Bovinae & 2 & & 17 & 2 & 21 \\
\hline Capra & & 1 & 3 & 9 & 13 \\
\hline Capra/Ovis & & 1 & 3 & 1 & 5 \\
\hline Odocoileus & & & 2 & 1 & 3 \\
\hline Ovis & & 1 & 15 & 18 & 34 \\
\hline Sus & & & 1 & & 1 \\
\hline Gallus & & & 2 & & 2 \\
\hline Meleagris & & & & 1 & 1 \\
\hline V. Ig. Mammal & 5 & & & & 5 \\
\hline Lg. Mammal & 3 & & & & 3 \\
\hline Total* & 10 & 6 & 154 & 47 & 217 \\
\hline
\end{tabular}

*Some bones had more than one type of butcher mark.

type of saw used could not be identified on two bones that conjoined. One other bone had been sawed with a machine saw, indicating that it was butchered in the twentieth century. The remainder of the sawed bone was cut with handsaws which is a nineteenth century butchering practice.
Most of the bones with butcher marks had been chopped. Of these only about 37 percent $(n=57)$ showed definite signs of having been chopped with a metal tool. The type of tool could not be determined on the others. They may have been chopped with either a metal tool or a stone tool. 
Forty-seven bones had impact scars where they had been broken with a blunt tool, a hammerstone or other blunt object. These marks were usually seen on the diaphyses of long bones. The bones were presumably broken open to extract marrow.

\section{Bone Tools}

One segment of long bone from a cow -sized animal, found in Unit 14, had been shaped into a tool (Figure 23). The tool, which is $8.1 \mathrm{~cm}$ long and $1.3 \mathrm{~cm}$ at the widest point, was probably an awl. Cut marks left when the bone was shaped are still clearly visible. There is a small amount of polishing on the tip, but the tool does not appear to have been heavily used after it was made.

A handle, probably for a metal knife, was also found in Unit 14 (Figure 24). The handle was obviously hand made, from the long bone of a cow-sized animal. The hole in which the tang rested runs the length of the handle. This artifact could be either Colonial or nineteenth century in origin.

\section{Pathologies}

Three sheep (Ovis aries) bone fragments at the joint of the humerus and radio-ulna show extensive pathology (Figure 25). All three bones forming the joint display evidence of severe inflammation, resulting in ossification of several tendons and other areas of excessive bone growth. Unfortunately the ulna was chopped very near this joint when the animal was butchered, so it is difficult to be sure, but it appears that this bone may have been injured, possibly crushed or broken, as it shows considerable remodeling underway along the medial side just distal of the semilunar notch (Figure 25a). If so, this injury seems to have been healing well. The severe inflammation of the other bones and the lateral side of the ulna seems

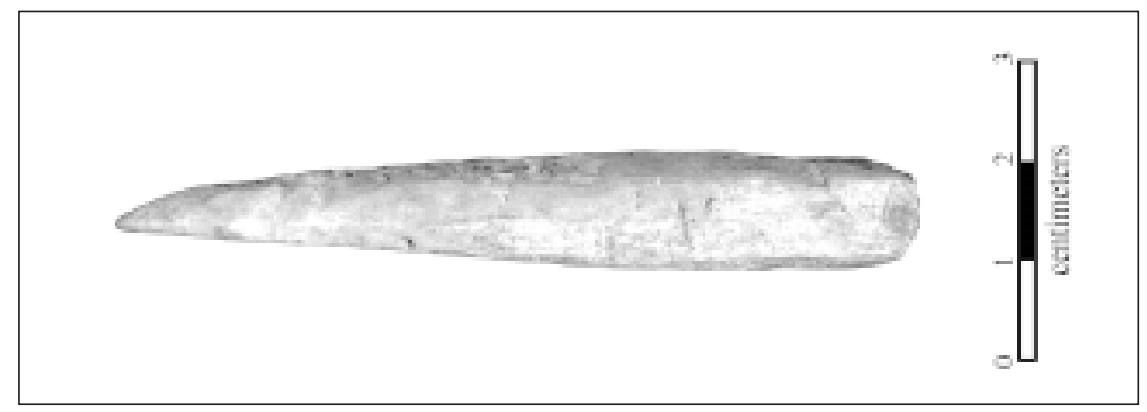

Figure 23. Bone Tool.

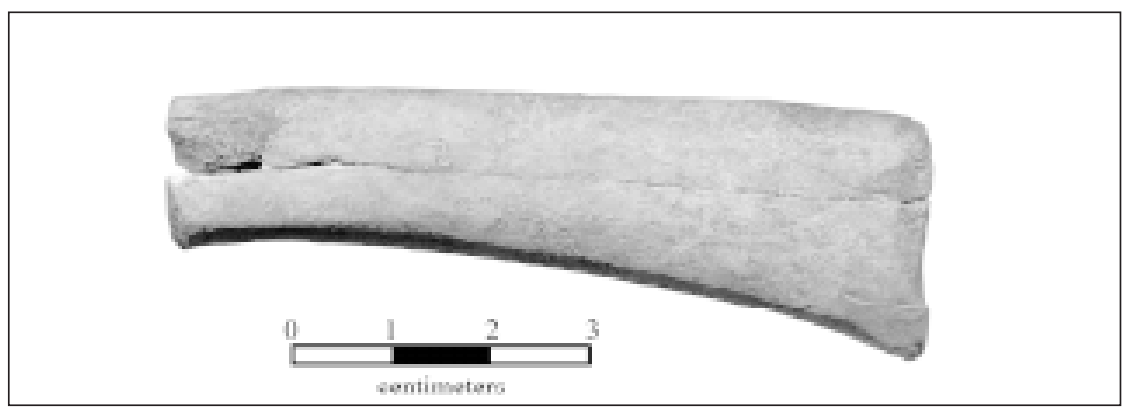

Figure 24. Bone Handle 
to be the result of osteomyelitis at the distal end of the humerus. The infection appears to be limited to the epiphysis, but the inflammation extended throughout what remains of the bones of the joint. There are three moderate-sized cloacas present (see Figure 25b), where puss had drained from the infection. The osteomyelitis is likely to have been a result of the same incident that injured the ulna.
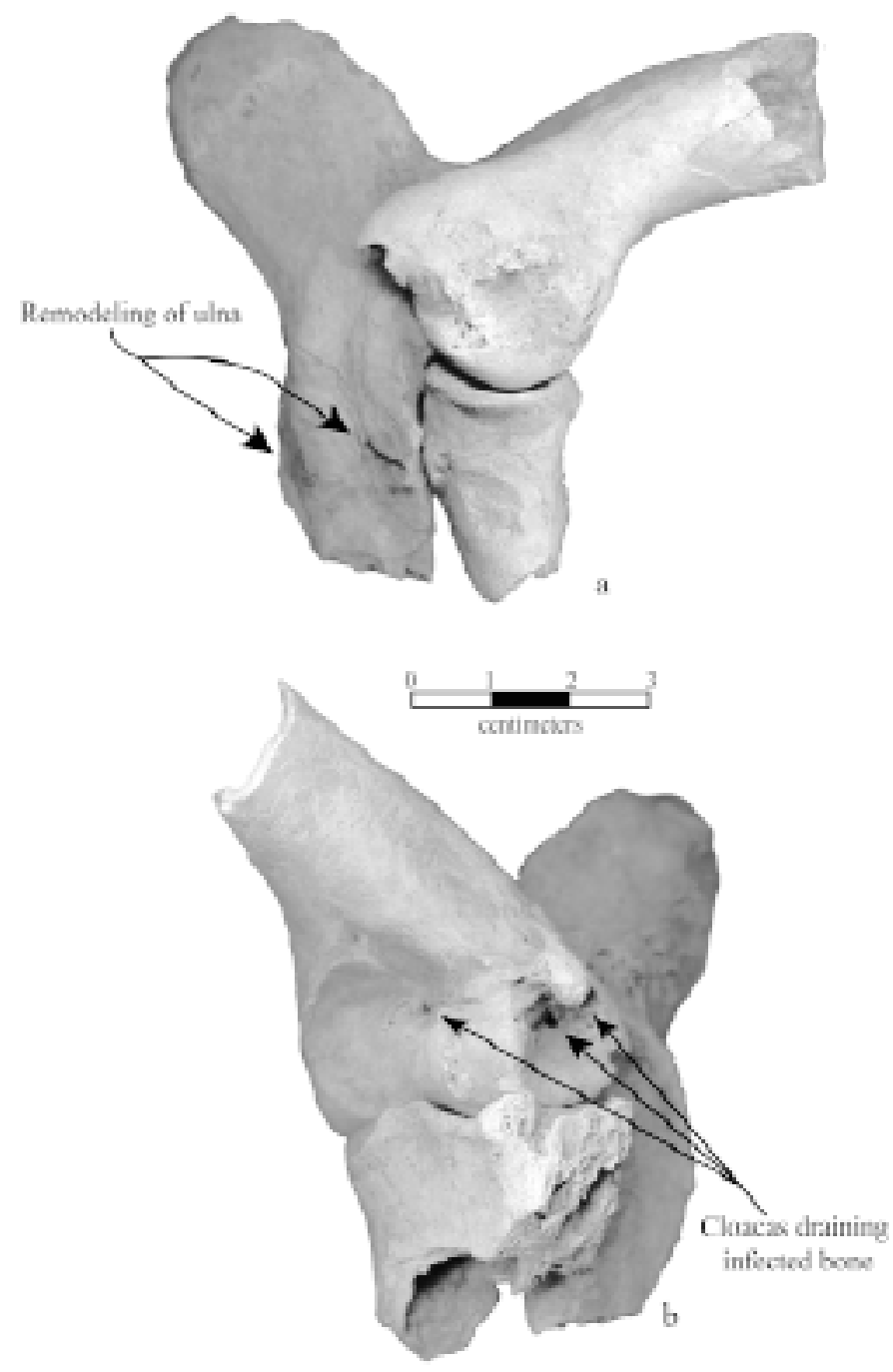

Figure 25. Two views of severe pathology in the elbow joint of a sheep from Unit 3: a) Lateral view; b) Posterior-medial view. 
Also from Unit 3 is the proximal end of a sheep humerus, with a thin cut from the lateral side through part of the epiphysis. This cut appears to have been made by a metal tool, some time before the animal died, as there is clear evidence of healing along the edge (Figure 26).

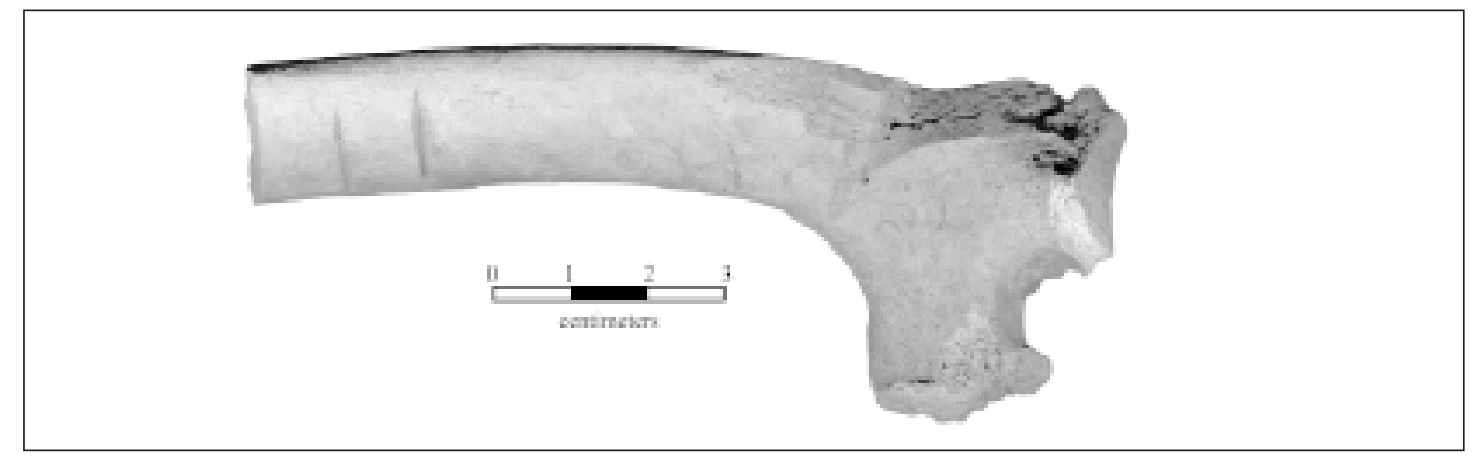

Figure 26. Proximal end of a sheep humerus with deep cut, shown in a lateral view turned slightly to the dorsal. Note: Healing along edges.

The proximal end of the posterior-lateral metapodial of a pig (Sus scrofa) from Unit 12 shows excessive bone growth that has destroyed the articular surface, leaving a rough mass of bone that would not have made an effective joint. However, since pigs carry their weight on the anterior phalanges, this would not necessarily have affected the gait of the animal to any great extent. This pathology could have been caused by an injury or a tumor.

\section{Evidence of Heat Alteration}

Evidence of exposure to heat can indicate whether bone was routinely thrown into the fire as a disposal method. Normally, cooking of meat, even over an open fire, will only smoke-stain or char the bone. The duration and intensity of heating necessary to calcine bone is considerable. It is unlikely to occur during routine cooking (Lyman 1994:388-389). Only 2.6 percent $(n=170)$ of the bone from this collection showed evidence of heat alteration. Of these, more than half (61.8 percent) were smoke-stained or charred, while 38.2 percent were partially calcined or calcined. A total of 21 of the latter (32.2 percent) were from a single level, level 5 in Unit A. The low percentage of burned bone and the low percentage of burned bone that was calcined or partially calcined is an indication that the project area was not a place were bone was usually disposed of by burning.

\section{Discussion}

\section{Comparison with Other Mission Collections}

This collection is very different from other collections of bone from mission sites in South Texas. In the first place, the bone was in somewhat better condition than usual, suggesting that its location was relatively sheltered from such taphonomic forces as trampling (including vehicular traffic).

More important, however, are the differences in relative abundance of the various genera compared to what can be considered a "typical" mission collection. Table 11 lists the NISP of selected genera from 6 recent mission collections, including the current project. The genera were chosen as the most economically import, as observed in Colonial sites. Bone from a project at the northwest gateway area of Espada (see Cargill 1999) is of particular interest, as this collection comes from an area only about $45 \mathrm{~m}$ from the current project area (see Figure 3). The gateway collection resembles the three collections from San José (Meissner 1998b, $1999 b, 1999$ c) as shown in Table 11, and together these four collections appear very different from the collection amassed during the current project. The collection from Mission Concepción is from a midden dumped into an acequia and is probably a butchering 
Table 11. Comparison of the NISP of Selected Genera from Three Mission sites in South Texas

\begin{tabular}{|c|c|c|c|c|c|c|c|c|c|c|c|c|}
\hline \multirow[b]{3}{*}{ Genera } & \multicolumn{4}{|c|}{ Espada } & \multicolumn{6}{|c|}{ San José } & \multirow{2}{*}{\multicolumn{2}{|c|}{$\begin{array}{c}\text { Concepción } \\
\text { Meissner } 2000\end{array}$}} \\
\hline & \multicolumn{2}{|c|}{ Current Project } & \multicolumn{2}{|c|}{ (Meissner 2000b) } & \multicolumn{2}{|c|}{ Meissner 1999b } & \multicolumn{2}{|c|}{ Meissner 1999c } & \multicolumn{2}{|c|}{ Meissner 1998} & & \\
\hline & Count & $\begin{array}{l}\% \text { of } \\
\text { total } \\
\text { NISP }\end{array}$ & Count & $\begin{array}{c}\% \text { of total } \\
\text { NISP }\end{array}$ & Count & $\begin{array}{l}\% \text { of } \\
\text { total } \\
\text { NISP } \\
\end{array}$ & Count & $\begin{array}{c}\% \text { of } \\
\text { total } \\
\text { NISP }\end{array}$ & Count & $\begin{array}{l}\% \text { of } \\
\text { total } \\
\text { NISP } \\
\end{array}$ & Count & $\begin{array}{c}\% \text { of } \\
\text { total } \\
\text { NISP } \\
\end{array}$ \\
\hline Bison & 0 & $0.0 \%$ & 0 & $0.0 \%$ & 12 & $2.7 \%$ & 0 & $0.0 \%$ & 0 & $0.0 \%$ & 11 & $2.9 \%$ \\
\hline Bos & 18 & $4.6 \%$ & 106 & $14.6 \%$ & 168 & $37.4 \%$ & 49 & $15.3 \%$ & 59 & $15.6 \%$ & 202 & $53.7 \%$ \\
\hline Capra & 16 & $4.1 \%$ & 8 & $1.1 \%$ & 4 & $0.9 \%$ & 3 & $0.9 \%$ & 7 & $1.8 \%$ & 1 & $0.3 \%$ \\
\hline Equus & 3 & $0.8 \%$ & 36 & $5.0 \%$ & 1 & $0.2 \%$ & 0 & $0.0 \%$ & 2 & $0.5 \%$ & 11 & $2.9 \%$ \\
\hline Odocoileus & 21 & $5.4 \%$ & 77 & $10.6 \%$ & 28 & $6.2 \%$ & 28 & $8.8 \%$ & 19 & $5.0 \%$ & 14 & $3.7 \%$ \\
\hline Ovis & 67 & $17.3 \%$ & 26 & $3.6 \%$ & 15 & $3.3 \%$ & 8 & $2.5 \%$ & 10 & $2.6 \%$ & 3 & $0.8 \%$ \\
\hline Sus & 10 & $2.6 \%$ & 30 & $4.1 \%$ & 43 & $9.6 \%$ & 0 & $0.0 \%$ & 6 & $1.6 \%$ & 2 & $0.5 \%$ \\
\hline Sylvilagus & 8 & $2.1 \%$ & 25 & $3.4 \%$ & 37 & $8.2 \%$ & 20 & $6.3 \%$ & 50 & $13.2 \%$ & 1 & $0.3 \%$ \\
\hline Gallus & 42 & $10.8 \%$ & 18 & $2.5 \%$ & 7 & $1.6 \%$ & 3 & $0.9 \%$ & 12 & $3.2 \%$ & 6 & $1.6 \%$ \\
\hline Meleagris & 7 & $1.8 \%$ & 9 & $1.2 \%$ & 0 & $0.0 \%$ & 5 & $1.6 \%$ & 6 & $1.6 \%$ & 5 & $1.3 \%$ \\
\hline Pseudomys & 0 & $0.0 \%$ & 3 & $0.4 \%$ & 36 & $8.0 \%$ & 45 & $14.1 \%$ & 11 & $2.9 \%$ & 18 & $4.8 \%$ \\
\hline Trionyx & 4 & $1.0 \%$ & 35 & $4.8 \%$ & 20 & $4.5 \%$ & 9 & $2.8 \%$ & 16 & $4.2 \%$ & 14 & $3.7 \%$ \\
\hline Ictalurus & 88 & $22.7 \%$ & 25 & $3.4 \%$ & 11 & $2.4 \%$ & 17 & $5.3 \%$ & 29 & $7.7 \%$ & 30 & $8.0 \%$ \\
\hline Pylodictus & 61 & $15.7 \%$ & 9 & $1.2 \%$ & 1 & $0.2 \%$ & 10 & $3.1 \%$ & 7 & $1.8 \%$ & 6 & $1.6 \%$ \\
\hline Total Selected Genera & 345 & $88.9 \%$ & 407 & $56.0 \%$ & 383 & $85.3 \%$ & 197 & $61.6 \%$ & 234 & $61.7 \%$ & 324 & $86.2 \%$ \\
\hline Total NISP & 388 & $100.0 \%$ & 727 & $100.0 \%$ & 449 & $100.0 \%$ & 320 & $100.0 \%$ & 379 & $100.0 \%$ & 376 & $100.0 \%$ \\
\hline
\end{tabular}

refuse area rather than a kitchen midden (Meissner 2000a), however, except for the unusually high percentage of cattle bone, and the near absence of wild animal bone, that collection resembles the typical Colonial period assemblage and is very different from the assemblage collected during the current project.

This difference is made even more clear in Table 12, which shows the percentage of NISP bone weight in 6 categories for the collections listed in Table 11 (note that the category Wild Mammals does not include rodents or carnivores). Again, the difference is notable, even compared to the gateway collection (Meissner 2000a), which was recovered so near the current project. Most striking is the large percentage of bone weight represented by domestic artiodactyls (Capra, Ovis, and Sus). In addition, there is a higher percentage of fish and birds, particularly chickens. Most of the other collections have higher percentage of bone weight in the Wild Mammal, and Turtle categories. Cattle bone makes up a much smaller percentage of NISP bone weight than is typically found in San Antonio missions.
Nature of the Bone Deposit

There are a number of possible reasons for the difference between this collection and other collections from mission sites in San Antonio. As mentioned above, the bone from the Concepción project shown in Table 11 and Table 1 is believed to be largely from a butchering discard pile outside the mission walls (Meissner 2000a:305). The bone from Mission San José listed in Table 11 and Table 1 is from several projects along the south wall of the mission, and probably represents a more generalized trash deposit. The bone from the current project, especially considering the probable use of the adjacent rooms, probably represents a kitchen midden.

However, this does not explain the particular makeup of this deposit. The differences between a butchering discard midden and a kitchen midden will be in the specific elements present (i.e., elements bearing more meat will more common in a kitchen midden than in a butchering discard midden), not in the species represented. If the bone was from a kitchen deposit used 
Table 12. Percentage of Total NISP Bone Weight in Six Categories from

Five recent Excavations, Compared to the Current Project

\begin{tabular}{|c|c|c|c|c|c|c|}
\hline \multirow[b]{3}{*}{ Categories } & \multicolumn{6}{|c|}{$\%$ of NISP Weight } \\
\hline & \multicolumn{2}{|c|}{ Espada } & \multicolumn{3}{|c|}{ San José } & Concepción \\
\hline & $\begin{array}{l}\text { Current } \\
\text { Project }\end{array}$ & $\begin{array}{c}\text { Meissner } \\
\text { 2000a }\end{array}$ & $\begin{array}{c}\text { Meissner } \\
1999 \mathrm{~b} \\
\end{array}$ & $\begin{array}{c}\text { Meissner } \\
1999 \mathrm{c} \\
\end{array}$ & $\begin{array}{c}\text { Meissner } \\
1998 \\
\end{array}$ & $\begin{array}{c}\text { Meissner } \\
\text { 2000b }\end{array}$ \\
\hline Cattle & $36.0 \%$ & $66.2 \%$ & $78.0 \%$ & $64.8 \%$ & $76.0 \%$ & $84.3 \%$ \\
\hline $\begin{array}{c}\text { Sheep, Goats, \& } \\
\text { Pigs }\end{array}$ & $33.2 \%$ & $5.1 \%$ & $6.3 \%$ & $6.5 \%$ & $6.3 \%$ & $0.7 \%$ \\
\hline Wild Mammals & $5.2 \%$ & $14.1 \%$ & $12.2 \%$ & $13.6 \%$ & $0.6 \%$ & $6.8 \%$ \\
\hline Birds & $3.2 \%$ & $0.5 \%$ & $0.4 \%$ & $1.3 \%$ & $1.1 \%$ & $0.4 \%$ \\
\hline Turtles & $0.7 \%$ & $2.2 \%$ & $2.4 \%$ & $4.4 \%$ & $1.5 \%$ & $1.3 \%$ \\
\hline Fish & $3.1 \%$ & $0.4 \%$ & $0.9 \%$ & $1.2 \%$ & $0.8 \%$ & $0.6 \%$ \\
\hline
\end{tabular}

by the entire mission, there should be much more cattle bone present. While differential processing of bone depending on species is probably common, there is no evidence of the type of processing of cattle bone for bone grease that will normally render it unidentifiable (see Meissner 1999c:39). Of the bone identified as bovid, 40.7 percent (33 of 81) were the type of bone usually made unidentifiable by processing for bone grease (Vehik 1977:172).

Another possible reason for the difference is that this deposit may be from the nineteenth century occupation of the adjacent rooms. There is a significant number of nineteenth century ceramics in the collection. A total of 35.9 percent (328 of 914) of ceramics are probably nineteenth century in origin (see section on ceramics), and these are found in all but the lowest level. There is evidence, however, that although disturbances have distributed some more recent artifacts into the lower levels of the units along Walls 3 and 4, the deposits below $40 \mathrm{~cm}$ in these units are largely Colonial in origin (see Depositional Integrity of the Site). Post-Colonial ceramic types (whiteware and stoneware) are present only in small numbers below $40 \mathrm{~cm}$ in the units adjacent to Walls 3 and 4 . Table 13 compares the bone from levels above $40 \mathrm{~cm}$ in the units adjacent to Walls 3 and 4 with bone from below $40 \mathrm{~cm}$ in those levels. The levels below $40 \mathrm{~cm}$ have more sheep and less chicken than the levels above 40 $\mathrm{cm}$, but otherwise, the two collections are remarkably similar. Given the fact that the majority of the NISP in these units (203 of 277) comes from below $40 \mathrm{~cm}$, in deposits believed to be largely Colonial, the similarity suggests that the entire bone collection is largely Colonial in origin, even though it does not resemble the "typical" Colonial bone collections shown in Table 11. This is consistent with two previous studies. Hard et al. (1995:85), in a series of 83 shovel tests and 4 test units in the compound at Mission San José, found that bone counts were strongly correlated with Colonial period ceramics, but not with nineteenth century ceramics. This pattern was also observed by Gross (1997:10-11), in a series of shovel tests in the New Plaza area of Espada.

The relative lack of saw-cut bone is more evidence that the bone is not of nineteenth century origin. Meissner and Hunziker (1997:301-302) found numerous saw-cut bone in a nineteenth century San Antonio deposit which was probably largely home-butchered, suggesting that even amateur butchers were using saws to cut meat by the middle of the century. The near absence of saw-cut bone in this collection is evidence, though certainly not proof, that it is mostly of Colonial origin.

Another possibility is that this collection represents differences in the diets of the Franciscan missionaries and their neophytes. This collection indicates a diet that is more diverse than is usually seen in Colonial period bone deposits, with much more mutton, chicken and fish supplementing the beef that was the mainstay of the mission diet (Meissner 1999b:305). 
Table 13. Comparison of Levels Above and Below $40 \mathrm{~cm}$ in Units Adjacent to Walls 3 and 4 Note: Bone collected during monitoring of the renovation of these walls is not included.

\begin{tabular}{|c|c|c|c|c|}
\hline \multirow[b]{2}{*}{ Genera } & \multicolumn{2}{|c|}{ Above $40 \mathrm{~cm}$} & \multicolumn{2}{|c|}{ Below $40 \mathrm{~cm}$} \\
\hline & Count & $\begin{array}{c}\% \text { of Total } \\
\text { NISP }\end{array}$ & Count & $\begin{array}{c}\% \text { of Total } \\
\text { NISP }\end{array}$ \\
\hline Bos & 2 & $2.7 \%$ & 10 & $4.9 \%$ \\
\hline Capra & 3 & $4.1 \%$ & 11 & $5.4 \%$ \\
\hline Equus & 1 & $1.4 \%$ & 1 & $0.5 \%$ \\
\hline Odocoileus & 1 & $1.4 \%$ & 5 & $2.5 \%$ \\
\hline Ovis & 7 & $9.5 \%$ & 40 & $19.7 \%$ \\
\hline Sus & 6 & $8.1 \%$ & 1 & $0.5 \%$ \\
\hline Sylvilagus & 1 & $1.4 \%$ & 1 & $0.5 \%$ \\
\hline Gallus & 13 & $17.6 \%$ & 12 & $5.9 \%$ \\
\hline Meleagris & 1 & $1.4 \%$ & 5 & $2.5 \%$ \\
\hline Trionyx & 0 & $0.0 \%$ & 1 & $0.5 \%$ \\
\hline Ictalurus & 26 & $35.1 \%$ & 43 & $21.2 \%$ \\
\hline Pylodictus & 2 & $2.7 \%$ & 49 & $24.1 \%$ \\
\hline Total Selected Genera & 63 & $85.1 \%$ & 179 & $88.2 \%$ \\
\hline Total NISP & 74 & $100.0 \%$ & 203 & $100.0 \%$ \\
\hline
\end{tabular}

There is no specific reference to any differences in diet between the missionaries and their neophytes in the available contemporary descriptions of mission life.

The reports that constitute the bulk of these records were written by the missionaries to inform their superiors about the indoctrination and progress of their charges, and such details as missionary diet were not discussed. However, there are a few hints that the missionaries did not eat the same meals as their neophytes. The instructions written for future missionaries by an unnamed missionary at Concepción about 1760 stressed the need to ensure that plenty of beans were available for the neophytes to eat during the traditional days of abstinence, so that...

"the natives have something to eat at noon and do not eat meat at home" (Leutenegger 1976:22).

The missionaries, however, were not required to limit themselves to beans. The anonymous missionary wrote:
"Also there is the fisherman who brings the fish in Advent, Lent and other days of abstinence for the missionaries use" (Leutenegger 1976:52),

and Fray Solís reported from San José in 1768 that...

"the old women fish so that the priests may have something to eat" (Habig 1978:149).

Part of the teaching of the missionaries to the Native Americans in the missions was a rigidly defined social hierarchy. This was, in the eyes of the missionaries, an important lesson:

"The submission of inferiors to the superior and subjects to the prelate is indispensable in communities and in pueblos. Without it nothing could well be managed, but all would end up in confusion and disorder. The missionary must so conduct himself toward the Indians so that all will show him respect, submission, and obedience" (Leutenegger 1976:48-49). 
One way to impress the social hierarchy on the neophytes could have been differences in diet. Chicken and sheep were probably considered better fare than beef. Governor Barrios, in a letter dated May 28, 1758, mentions that "chicken and mutton are also given to the sick" (Habig 1978:131). This implies that chicken and mutton were considered more digestible and perhaps more nutritious than beef.

However, even if the missionary had wanted to share a more diverse diet with his charges, neither chicken nor mutton would have been available in large enough quantities to supply the large number of neophytes. Although a few chickens could have been kept with little extra food, by allowing them to forage for themselves during the day, there would not have been enough of them to supply the neophytes. We know that there were large numbers of sheep at the missions. Inventories indicate that the herds of ganado menor ("minor livestock", i.e., goats and sheep) increased steadily throughout the mission period (see Hard et al. 1995:81). There were enough so those males deemed unneeded were routinely castrated and shipped back to Mexico (Leutenegger 1976:35). However, sheep were needed for their wool, and could not have been used extensively for the neophyte's meat diet without seriously impacting the size of the herd. The missionaries may have been able to have a more diverse meat diet than their neophytes because they could provide plenty of beef to the other mission inhabitants while providing themselves with the less readily available, and possibly more desirable meats.

\section{Summary and Conclusion}

A total of 6,485 vertebrate faunal remains, weighing $12,542.15 \mathrm{~g}$, was recovered in units along the walls outside the Priests quarters at Mission Espada. This collection is unusual for Colonial period sites in San Antonio, as it is not dominated by cattle bone. Large numbers of sheep, chicken, and fish bone are present.

Reitz and Scarry (1985:84) caution against inferring too much from data from a single feature, especially in Historic sites. They point out that specialized trash dumps (e.g., kitchen middens versus butchering waste middens) will give a false impression of behavior at the site if they are the only features excavated. Certainly, if data from this project were considered in isolation, a false picture of the typical mission diet in San Antonio would have been created. The two most likely explanations for the differences between this collection and the typical Colonial fauna collection are that either the deposit is largely nineteenth century in origin, or that it represents the specialized diet of the missionaries rather than the Native American neophytes at the mission.

It is difficult to evaluate the likelihood that a significant portion of the bone from this collection is from the nineteenth century occupation, rather than the Colonial occupation, of the site. Most of the unit/levels appeared mixed, with both Colonial and nineteenth century ceramics present. The similarity between the bone from mixed contexts and from contexts that are probably largely Colonial indicates that the collection is largely Colonial in origin, even though the bone from this project is very different from the bone usually seen in Colonial bone deposits. The near absence of sawed bone is another indicator that the bone was deposited in the Colonial period.

The fact that this bone comes from disturbed deposits means that some caution is required in making statements about the nature bone deposit. On the other hand, it is not unlikely that the missionaries had a diet somewhat different than the Native American neophytes in the mission. The higher social status of the friars made it possible to get sheep, chicken, fish, and occasional hunted foods, as well as beef, allowing them a more varied meat diet. Future opportunities to examine faunal material from the mission may help to determine if this collection does, in fact, represent the diet of the missionaries. 


\section{Summary and Recommendations}

As a result of these investigations, definite conclusions as to the age of the three southernmost structures of the Convento are advanced. While monitoring the work in-progress, it was noted that the structural integrity of the walls was compromised. The excavations also resulted in the location of two stone alignments; these were designated Features A and B. The type and density of the recovered cultural material, especially ceramics, indicate that a very small area along the south-end of the Convento appears to be moderately disturbed. In terms of the mission diet, the faunal analysis suggest an interesting deviation from the norm.

As a result of monitoring the work in-progress, it was noted that Walls 1, 2, 3, 4, and 5 were severely impacted by the undercutting, to the extent that the Colonial period footers and later additions were lost. All five wall footers and Features A and B were systematically documented during the course of this investigation. Although seemingly extreme, this was a valid form of structural intervention since the walls were beginning to buckle and Wall 3 was noticeably outof-plumb. This form of conservation and consolidation was designed to ensure the building's overall structural integrity.

The most likely mission-period layout for the Convento is that depicted by Corner at ca. 1890, which implies that the present-day appearance is speculative. The south-end of the Convento would have consisted of, from east to west, the kitchen, dining room, and two-story friary (see Figure 5). Although these photographs were taken at least 50 years after final secularization, the ca. 1890-1930 photos are valuable sources for tracing the post-mission period evolvement of the Convento. Adding to this valuable source are the HABS photographs taken in 1934, as well as the Measured Drawings of Harvey P. Smith.
Two connecting stone alignments were encountered along Walls 2 and 3, and these were designated Features B and A, respectively. Unfortunately, given the specifications of the wall stabilization work, it was impossible to preserve these features. Excavations along Wall 1 and Wall 2 indicated that portions of this ca. 1956 Priest quarters may in fact be constructed on remnants of Spanish Colonial footers. However, the existence of Feature B along Wall 2 is problematic, since we are interpreting this as a wall foundation (see Figure 6). Feature B runs parallel to Wall 2 and Feature A runs parallel to Wall 3. If both features are considered a unit, rather than distinct wall footers, it would then appear that they represent a method of additional shoring up at this intersection of two walls (i.e., banqueta or buttress). Although the wall footers and features were comparable in depth, the interpretation of these two features as wall footers is questionable for two reasons. First of all, undercutting and monitoring of the Wall 1, 2, 3, 4 and 5 footers allowed us to determine the typical width of the wall footers as being ca. $92 \mathrm{~cm}$ (36") wide, while Features A and B are $80 \mathrm{~cm} \mathrm{(31")} \mathrm{and} 60 \mathrm{~cm}$ (23") wide, respectively. Secondly, we were also able to note that the typical wall footer was constructed of rock-rubble and mud backfill, while the construction of Features A and B exhibited clear indications of stacking in a weakly cemented, clay-like mortar.

As previously discussed the area along Walls 1 and 2 (rectory) has been heavily impacted by constructionrelated activities over the past 50 years; this was clearly illustrated in Figures 22 and 24. In contrast, the area along Walls 3 and 4 (dining room) has not been as heavily impacted and the deposition appears to be somewhat intact. This suggests that the restoration work of Harvey P. Smith only required a minimal amount of subsurface excavations along the dining room. An analysis of the Wall 5 (kitchen) data failed 
to reveal any definite depositional patterns. This is probably owing to the comparatively smaller area excavated and the low number of artifacts recovered.

The recovery of five gunflints and four strike-a-lites indicates that flintlock guns were a common occurrence at the mission and that the neophytes had begun to shift to an EuroAmerican fire-making technology. In considering this same collection, it was interesting to note that Guerrero points were not recovered. It may be that none were found given that this collection is representative of the material used by the Franciscan inhabitants of the mission rather than that of the Indian neophytes. The recovery of a Frenchmade gunflint supports this interpretation. Overall, the lithic collection from this investigation was rather small. And although the analysis focused on identifying distinct components within the small lithic sample, the vertical distribution of these artifacts proved inconclusive. Four of the five gunflints, two strike-alites, one of two scrapers, and an Edwards arrow point stem were recovered from the upper $30 \mathrm{~cm}$ of deposits. And while no tools were recovered in the next 20 $\mathrm{cm}$, two strike-a-lites, a French gunflint, a scraper, and the single core were recovered from $50-80 \mathrm{~cm}$ below surface. These distributions do not reflect two distinct archaeological components.

The faunal analysis revealed some atypical characteristics for this site. Unlike other Colonial period sites in San Antonio, this collection was not dominated by cattle bone. Instead, large numbers of sheep, goat and fish bone were present. The two most likely explanations for this deviation are that either the deposit is largely nineteenth century in origin, or it represents the specialized diet of the missionaries rather than the Native American neophytes at the mission. Since the Convento has been continuously occupied for 270 years, and by no less than five culturally distinct occupants, neither one of these two explanations is easy to corroborate at this time. In summary, this study has resulted in the recovery of invaluable cultural data, and adds considerably to the growing body of research relating to the South Texas missions. 


\section{References Cited}

Almaráz, Felix D.

1982 Land Tenure Study of the San Antonio Missions. Report prepared for the San Antonio Missions National Historical Park, National Park Service, San Antonio.

Balkwill, D. M., and S. L. Cumbaa

1992 A Guide to the Identification of Postcranial Bones of Bos taurus and Bison bison. Canadian Museum of Nature, Ottawa.

Barnes, M. R., and R. V. May

1972 Mexican Majolica in Northern New Spain. Pacific Coast Archaeological Society Occasional Paper, No. 2, Costa Mesa, CA.

Boessneck, J.

1970 Osteological Differences Between Sheep (Ovis aries Linné) and Goats (Capra hircus Linné). In Science in Archaeology, edited by D. Brothwell and E. Higgs, pp. 331-358. Praeger, New York.

Cargill, D. A.

1999 Untitled report on the Mission Espada Hike and Bike Trail, 1998 and 1999. Preliminary manuscript on file at the Center for Archaeological Research, The University of Texas at San Antonio.

Cargill, Diane A., Maureen Brown, Lee C. Nordt, and C. Britt Bousman

1998 Archaeological Survey at Rancho de las Cabras, San Antonio Missions National Historical Park, 41WN30, Wilson County, Texas. Archaeological Survey Report, No. 286. Center for Archaeological Research, The University of Texas at San Antonio.

Cohen, A., and D. Serjeantson

1996 A Manual for the Identification of Bird Bones from Archaeological Sites. Revised edition. Archetype Publications, London.

Escobedo, S.

1984 Untitled report on 1984 excavations at Mission Espada. Manuscript on file at the Center for Archaeological Research, The University of Texas at San Antonio.

Foster, William C.

1995 Spanish Expeditions into Texas, 1689-1768. University of Texas Press, Austin

Fox, A. A.

1974 Lead Glazed Wares. In Mission Rosario, Archeological Investigation in 1973, by K. Gilmore. Archaeological Report 14, Part I. Texas Parks and Wildlife Department, Parks Division, Historic Sites and Restoration Branch, Austin.

1981 Test Excavations at Mission San Francisco de la Espada. Archaeological Survey Report, No. 108, Center for Archaeological Research, The University of Texas at San Antonio.

1983 Monitoring of nine test cores at Mission San Juan and one at Mission Espada. Letter report on file at the Center for Archaeological Research, The University of Texas at San Antonio. 
Fox, A. A., and T. R. Hester

1976 Archaeological Test Excavations at Mission San Francisco de la Espada. Archaeological Survey Report, No. 22. Center for Archaeological Research, The University of Texas at San Antonio.

Fox, D. E.

1979 The Lithic Artifacts of Indians at the Spanish Colonial Missions, San Antonio, Texas. Special Report 8. Center for Archaeological Research, The University of Texas at San Antonio.

Gerald, R. E.

1957 A Historic House Excavation Near Janos, Northwest Chihuahua, Mexico. Master's Thesis, University of Pennsylvania.

1968 Spanish Presidios of the Late Eighteenth Century in Northern New Spain. Museum of New Mexico Research Records No. 7. Museum of New Mexico Press, Santa Fe.

Gilbert, B. M.

1990 Mammalian Osteology. Missouri Archaeological Society, Columbia.

Goggin, J. M.

1968 Spanish Majolica in the New World, Types of the Sixteenth to Eighteenth Centuries. Department of Anthropology, Yale Publications in Anthropology, No. 72. Yale University.

Graham, Joe

1978 Folk Housing in South and West Texas: Some Comparisons. In Proceedings - An Exploration of a Common Legacy: A Conference on Border Architecture, Marlene Elizabeth Heck, Project Director, Texas Historical Commission, Austin.

Grayson, D. K.

1984 Quantitative Zooarchaeology. Academic Press, New York.

Gross, K. J.

1997 Archaeological Testing of the New Plaza at Mission San Francisco de la Espada (41BX4), San Antonio, Texas. Archaeological Survey Report No. 262, Center for Archaeological Research, The University of Texas at San Antonio.

Habig, Marion A.

1968 The Alamo Chain of Missions. Franciscan Herald Press, Chicago.

Habig, Marion A. (compiler)

1978 The San José Papers: The Primary Sources for the History of the Mission San José y San Miguel de Aguayo from its Founding in 1720 to the Present. Part I: 1719-1791. Translated by B. Leutenegger et al. Old Spanish Missions Historical Research Library at Mission San José, San Antonio.

Hard, R. J., and A. A. Fox (editors)

1995 Excavations at Mission San José y San Miguel de Aguayo, San Antonio, Texas. Archaeological Survey Report No. 218, Center for Archaeological Research, the University of Texas at San Antonio. 
Hester, T. R.

1971 Archeological Investigations at the La Jita Site, Uvalde County, Texas. Bulletin of the Texas Archeological Society 42:51-138.

1977 The Lithic Technology of Mission Indians in Texas and Northeastern Mexico. Lithic Technology 6(1):913.

Highley, L., C. Graves, C. Land, and G. Judson

1978 Archeological Investigations at Scorpion Cave (41ME7), Medina County, Texas. Bulletin of the Texas Archeological Society 49:139-198.

Hildebrand, M.

1955 Skeletal Differences Between Deer, Sheep, and Goats. California Fish and Game 41:327-346.

Hillson, S.

1986 Teeth. Cambridge University Press, Cambridge.

Ivey, J. E., and A. A. Fox

1981 Archaeological Survey and Testing at Rancho de las Cabras, Wilson County, Texas. Archaeological Survey Report, No. 104, Center for Archaeological Research, The University of Texas at San Antonio.

Ivey, James E., Marlys Bush Thurber, and Santiago Escobedo

1990 Of Various Magnificence: The Architectural History of the San Antonio Missions in the Colonial Period and the Nineteenth Century. Volume One, National Park Service Professional Papers No. 11, Santa Fe, Draft on file at the Center for Archaeological Research, The University of Texas at San Antonio.

Kendrick, Grace

1966 The Antique Bottle Collector. Edwards Brothers, Inc., Michigan.

Kenmotsu, N.

1990 Gunflints: A Study. Historical Archaeology 24(2):92-124.

Kent, B. C.

1983 More on Gunflints. Historical Archaeology 17(2):27-33.

Killen, K., and D. Scurlock

1976 Report on Preliminary Test Excavations at Mission Espada Kilns, San Antonio, Texas, Manuscript on file, Center for Archaeological Research, The University of Texas at San Antonio.

Leutenegger, B. (editor and translator)

1976 Guidelines for a Texas Mission: Instructions for the Missionary of Mission Concepción in San Antonio. Old Spanish Missions Historical Research Library at San José Mission, San Antonio.

Lister, F. C., and R. H. Lister

1974 Majolica in Colonial Spanish America. Historical Archaeology, 8:17-52.

Logan, Herschel C.

1959 Cartridges: A pictorial digest of small arms ammunition. Bonanza Books, New York. 
Lyman, R. L.

1994 Vertebrate Taphonomy. Cambridge University Press, Cambridge.

Lyman, R. L., and M. J. O'Brien

1987 Plow-Zone Zooarchaeology: fragmentation and identifiability. Journal os Archaeological Science 16:293-317.

Meissner, B. A.

1998a Archaeological Monitoring of an Electrical Conduit Trench at Mission San Francisco de la Espada (41BX4), San Antonio, Bexar County, Texas. Archaeological Survey Report, No. 288, Center for Archaeological Research, The University of Texas at San Antonio.

1998b Vertebrate Faunal Remains. In Mission San José Indian Quarters Foundation Project, Bexar County, Texas: With Appendixes on the Monitoring of the San José Bus Drive and Granary Parking Lot, and on the Monitoring and Shovel Testing of the San José Service Drive, by S. A. Tomka and A. A. Fox. Archaeological Survey Report, No. 278. Center for Archaeological Research, The University of Texas at San Antonio.

1999a Vertebrate Faunal Remains. In Archaeological Investigations of Rainwater Catchment Basins Along the South Wall of Mission San José, San Antonio, Texas, by S. A. Tomka and A. A. Fox, pp. 39-46. Archaeological Survey Report No. 287, Center for Archaeological Research, the University of Texas at San Antonio.

1999b Analysis of Vertebrate Faunal Remains from a Spanish Colonial Deposit at Mission San Antonio de Valero (the Alamo). Bulletin of the Texas Archeological Society 70:281-313.

1999c Vertebrate Faunal Remains. In Mission San José Repointing and Underpinning Project, San Antonio, Texas, by S. A. Tomka, A. A. Fox, and B. A. Meissner, pp. 35-41. Archaeological Research Report No. 294, Center for Archaeological Research, the University of Texas at San Antonio.

2000a Mission Concepción. In Archaeological Investigations at Four San Antonio Missions: Mission Trails Underground Conversion Project, edited by C. L. Tennis, pp. 59-99. Archaeological Survey Report No. 297, Center for Archaeological Research, The University of Texas at San Antonio.

Meissner, B. A., and J. M. Hunziker

1997 Analysis of Vertebrate Faunal Remains from the Alamodome Project. In Archaeology at the Alamodome: Investigations of a San Antonio Neighborhood in Transition, Vol. III, Artifact and Special Studies, edited by Anne A. Fox and Robert J. Hard, pp. 286-344. Center for Archaeological Research, University of Texas at San Antonio.

Meskill, F. K.

1992 Archaeological Testing Within the Southeast Corner of the Plaza at Mission Espada, San Antonio, Bexar County, Texas. Archaeological Survey Report, No. 208, Center for Archaeological Research, The University of Texas at San Antonio.

Mitchell, J. L.

1978 The Turtle Creek Phase: An Initial Late Prehistoric Component in Southern Texas. La Tierra 5(4):3245.

Mounger, M. A.

1959 Mission Espiritu Santo of Coastal Texas: An Example of Historic Site Archeology. Master's Thesis, The University of Texas at Austin. 
Nelson, Lee H.

1968 Nail Chronology as an aid to dating old buildings. American Association for State and Local History Technical Leaflet 48. History News Vol. 24, No. 11.

Olsen, Stanley J.

1960 Post-Cranial Skeletal Characters of Bison and Bos. Peabody Museum, Cambridge.

1964 Mammal Remains from Archaeological Sites Part I; Southeastern and Southwestern United States. Peabody Museum, Cambridge.

1968 Fish, Amphibian, and Reptile Remains from Archaeological Sites Part I: Southeastern and Southwestern United States. Peabody Museum, Cambridge.

Petretti, Allan

1999 "History of Barq's Root Beer." [9 paragraphs] Pop Central Articles. February 13, 1999. [Online] http://www.nostalgiapubs.com/articles/barqhistory.htm (December 20, 1999).

Reitz, E. J., and C. M. Scarry

1985 Reconstructing Historic Subsistence with an Example from Sixteenth-Century Spanish Florida. Special Publications No. 3, Society for Historical Archaeology, Ann Arbor, MI.

Reitz, E. J., and E. S. Wing

1999 Zooarchaeology. Cambridge University Press, Cambridge.

Schmid, E.

1972 Atlas of Animal Bones for Prehistorians, Archaeologists, and Quaternary Geologists (Knochenatlas Für Prähistoriker, Archäologen und Quartärgeologen). Elsevier Publishing, Amsterdam.

Schuetz, Mardith K.

1968 The History and Archeology of Mission San Juan Capistrano, San Antonio, Texas. Archeology Special Report, No. 11, State Building Commission Archeology Program.

1969 The History and Archeology of Mission San Juan Capistrano, San Antonio, Texas (Vol. 2). Description of the Artifacts and Ethnohistory of the Coahuiltecan Indians. State Building Commission, Archeology Program Report 11. Austin.

1980 The Indians of the San Antonio Missions, 1718-1821. Ph.D. dissertation, The University of Texas at Austin.

Smith, Harvey P., Jr.

1980a Mission Espada: Research and Restoration. La Tierra 7(2):3-18.

1980b Developmental Phases at Mission San Francisco de la Espada. La Tierra 7(4):36-39.

Sobolik, K. D., and D. G. Steele

1996 A Turtle Atlas to Facilitate Archaeological Identifications. Mammoth Site of Hot Springs, SD, Inc., Rapid City, SD.

Sollberger, J. B.

1978 A New Type of Arrow Point with Speculations as to its Origin. La Tierra 5(4):13-20

Sullivan, A. P., and K. C. Rozen

1985 Debitage Analysis and Archaeological Interpretation. American Antiquity 50:755-779. 
Thurber, Marlys Bush, Santiago Escobedo, Tom Ireland, and James E. Ivey

1993 Of Various Magnificence: The Architectural History of the San Antonio Missions in the Colonial Period and the Nineteenth Century. Volume Two, National Park Service Professional Papers No. 11, Santa Fe, Draft on file at the Center for Archaeological Research, The University of Texas at San Antonio.

Tomka, S. A.

1989 Differentiating Lithic Reduction Techniques: An Experimental Approach. In Experiments in Lithic Technology, edited by D. S. Amick and R. P. Mauldin. BAR International Series 528, pp. 137-161.

Tomka, Steve A., and Anne A. Fox

1998 Mission San Jose Indian Quarters Wall Base Project, Bexar County, Texas: With Appendixes on the Monitoring of the San Jose Bus Drive and Granary Parking Lot, and on the Monitoring and Shovel Testing of the San Jose Service Drive. Christopher E. Horrell, Barbara A. Meissner, and Ricky Robinson, contributors. Archaeological Survey Report, No. 278, Center for Archaeological Research, The University of Texas at San Antonio.

1999 Archaeological Investigations of Rainwater Catchment Basins along the South Wall of Mission San José, San Antonio, Texas. Archaeological Survey Report No. 287, Center for Archaeological Research, The University of Texas at San Antonio.

Toulouse, Julian Harrison

1971 Bottle Makers. Thomas Nelson Inc. Camden, New Jersey.

Turner, E. S., and T. R. Hester

1993 A Field Guide to Stone Artifacts of Texas Indians. Second Edition. Texas Monthly Field Guide Series, Gulf Publishing Co., Houston.

Vaughn, Mary

1997 Kitchen Utensils and Tableware. In Archaeology at the Alamodome: Investigations of a San Antonio Neighborhood in Transition; Volume III: Artifacts and Special Studies. Anne A. Fox, Marcie Renner, and Robert J. Hard, editors, Archaeological Survey Report, No. 238, Center for Archaeological Research, The University of Texas at San Antonio.

Vehik, S. C.

1977 Bone Fragments and Bone Grease Manufacturing: A Review of Their Archaeological Use and Potential. Plains Anthropologist 22:169-182.

Von Endt, D. W., and D. J. Ortner

1984 Experimental Effects of Bone Size and Temperature on Bone Diagenesis. Journal of Archaeological Science 11:247-253.

Yeoman, R. S.

1967 A Guide Book of United States Coins. Whitman Publishing Company, Racine, Wisconsin.

Zapata, José E.

1995 Alamodome and Abroad: A Composite Inquiry on Toy Marbles. In Archaeology at the Alamodome: Investigations of a San Antonio Neighborhood in Transition; Volume III: Artifacts and Special Studies. R. J. Hard and A. A. Fox, editors, Archaeological Survey Report, No. 262, Center for Archaeological Research, The University of Texas at San Antonio. 


\section{Archives Consulted}

\section{AA-APL}

Harvey P. Smith Drawings of the San Antonio Missions, Alexander Architectural Archive, Architecture and Planning Library, The University of Texas at Austin.

ASA

Archdiocese of San Antonio.

CAT

Catholic Archives of Texas, Austin.

ITC

Photo Library, The University of Texas Institute of Texan Cultures at San Antonio.

NPS

James E. Ivey Conceptual Drawings (n.d.) of Mission Espada, 1772 and 1824-1827, and Photo Collection, San Antonio Missions, National Historical Park, National Park Service Headquarters, San Antonio. 



\section{Appendix A}

Artifact Summary 
Appendix A

\begin{tabular}{|c|c|c|c|c|c|c|c|c|c|c|c|}
\hline Artifact Tyne & Level 1 (0. & Level 2 (10. & Level 3 (20. & Level 4 (30- & Level 5 (40. & Level 6 (50. & Level 7 (60- & Level 8 (70. & Level 9 (80 & Totale & \\
\hline Artifact Type & 10) & 20) & 30) & 40) & 50) & 60 & $70)$ & 80 & $90)$ & Totals & $\%$ of Total \\
\hline Lithics: & 3 & 3 & 6 & 4 & 6 & 7 & 1 & 1 & 0 & 31 & $1 \%$ \\
\hline Ceramics Total: & 53 & 75 & 50 & 49 & 36 & 34 & 13 & 3 & 0 & 313 & $7 \%$ \\
\hline Diagnostic Glass & 6 & 14 & 8 & 4 & 11 & 5 & 11 & 0 & 1 & 60 & \\
\hline Glass Fragments & 145 & 207 & 161 & 103 & 76 & 66 & 38 & 14 & 2 & 812 & \\
\hline Lamp Glass & 33 & 47 & 4 & 15 & 6 & 1 & 6 & 0 & 0 & 112 & \\
\hline Caps, Tops & 21 & 19 & 21 & 10 & 8 & 8 & 5 & 0 & 0 & 92 & \\
\hline Tableware & 0 & 0 & 0 & 0 & 0 & 1 & 0 & 0 & 0 & 1 & \\
\hline Kitchenware & 0 & 0 & 1 & 0 & 0 & 0 & 0 & 0 & 0 & 1 & \\
\hline Other Household & 5 & 1 & 1 & 5 & 0 & 0 & 0 & 0 & 0 & 12 & \\
\hline Kitchen/Household Total: & 263 & 363 & 246 & 186 & 137 & 115 & 73 & 17 & 3 & 1403 & $30 \%$ \\
\hline Window Glass & 326 & 232 & 119 & 78 & 67 & 61 & 25 & 6 & 2 & 916 & \\
\hline Wire nails & 195 & 156 & 148 & 94 & 67 & 47 & 32 & 6 & 2 & 747 & \\
\hline Cut nails & 2 & 8 & 7 & 9 & 6 & 10 & 0 & 1 & 1 & 44 & \\
\hline Screws & 13 & 3 & 2 & 0 & 0 & 0 & 0 & 0 & 0 & 18 & \\
\hline Nuts & 1 & 0 & 0 & 0 & 0 & 0 & 0 & 0 & 0 & 1 & \\
\hline Bolts & 1 & 0 & 0 & 0 & 0 & 0 & 0 & 0 & 0 & 1 & \\
\hline Other Hardware & 18 & 8 & 4 & 0 & 0 & 1 & 0 & 0 & 0 & 31 & \\
\hline Brick, Tile & 50 & 37 & 29 & 14 & 19 & 19 & 6 & 0 & 0 & 174 & \\
\hline Mortar & 3 & 2 & 2 & 1 & 2 & 20 & 3 & 2 & 0 & 35 & \\
\hline Plaster & 0 & 0 & 0 & 0 & 0 & 0 & 0 & 0 & 0 & 0 & \\
\hline Concrete & 0 & 0 & 0 & 1 & 0 & 0 & 0 & 0 & 0 & 1 & \\
\hline Asphalt & 0 & 0 & 1 & 0 & 0 & 0 & 0 & 0 & 0 & 1 & \\
\hline Electrical Items & 91 & 59 & 8 & 4 & 0 & 0 & 0 & 0 & 0 & 162 & \\
\hline Other Constr. & 10 & 104 & 16 & 38 & 30 & 8 & 0 & 3 & 0 & 209 & \\
\hline Construction Total: & 710 & 609 & 336 & 239 & 191 & 166 & 66 & 18 & 5 & 2340 & $51 \%$ \\
\hline Buttons & 0 & 2 & 0 & 1 & 1 & 0 & 0 & 0 & 0 & 4 & \\
\hline Buckles & 0 & 0 & 0 & 0 & 0 & 0 & 0 & 0 & 0 & 0 & \\
\hline Shoe Parts & 0 & 1 & 0 & 0 & 0 & 0 & 0 & 0 & 0 & 1 & \\
\hline Other Clothing & 1 & 0 & 0 & 0 & 0 & 0 & 0 & 0 & 0 & 1 & \\
\hline Beads & 0 & 0 & 0 & 0 & 1 & 0 & 1 & 0 & 0 & 2 & \\
\hline Jewelry & 0 & 0 & 0 & 0 & 0 & 0 & 0 & 0 & 0 & 0 & \\
\hline Grooming & 0 & 2 & 0 & 0 & 0 & 0 & 0 & 0 & 0 & 2 & \\
\hline Coins & 1 & 1 & 1 & 0 & 0 & 0 & 0 & 0 & 0 & 3 & \\
\hline Other Personal & 0 & 0 & 0 & 1 & 0 & 1 & 1 & 0 & 0 & 3 & \\
\hline Clothing/Personal Total: & 2 & 6 & 1 & 2 & 2 & 1 & 2 & 0 & 0 & 16 & $0 \%$ \\
\hline Toys & 0 & 1 & 0 & 1 & 0 & 0 & 0 & 0 & 0 & 2 & \\
\hline Writing Material & 0 & 0 & 0 & 1 & 0 & 1 & 0 & 0 & 0 & 2 & \\
\hline Other Activities & 0 & 0 & 0 & 0 & 1 & 0 & 0 & 1 & 0 & 2 & \\
\hline Activity Total: & 0 & 1 & 0 & 2 & 1 & 1 & 0 & 1 & 0 & 6 & $0 \%$ \\
\hline Shell casings & 0 & 0 & 0 & 0 & 0 & 0 & 0 & 0 & 0 & 0 & \\
\hline Other arms & 1 & 1 & 0 & 2 & 1 & 1 & 0 & 1 & 0 & 7 & \\
\hline Arms Total: & 1 & 1 & 0 & 2 & 1 & 1 & 0 & 1 & 0 & 7 & $0 \%$ \\
\hline Tools & 0 & 0 & 3 & 1 & 3 & 0 & 0 & 0 & 0 & 7 & \\
\hline Wire & 18 & 14 & 1 & 10 & 11 & 3 & 1 & 1 & 0 & 59 & \\
\hline Horseshoes & 0 & 0 & 0 & 0 & 0 & 0 & 0 & 0 & 0 & 0 & \\
\hline Machinery & 0 & 1 & 1 & 0 & 0 & 1 & 0 & 0 & 0 & 3 & \\
\hline Other Workshop & 21 & 5 & 2 & 1 & 1 & 0 & 2 & 0 & 0 & 32 & \\
\hline Barn/Workshop Total: & 39 & 20 & 7 & 12 & 15 & 4 & 3 & 1 & 0 & 101 & $2 \%$ \\
\hline Copper scrap & 50 & 3 & 10 & 0 & 2 & 23 & 1 & 0 & 0 & 89 & \\
\hline Iron scrap & 78 & 37 & 27 & 12 & 5 & 8 & 7 & 0 & 2 & 176 & \\
\hline Other Metal & 6 & 8 & 3 & 3 & 0 & 0 & 0 & 0 & 0 & 20 & \\
\hline Unident'fd Metal & 3 & 3 & 2 & 2 & 0 & 2 & 1 & 1 & 0 & 14 & \\
\hline Metal Total: & 137 & 51 & 42 & 17 & 7 & 33 & 9 & 1 & 2 & 299 & $6 \%$ \\
\hline Seeds, Pits & 0 & 0 & 1 & 0 & 0 & 6 & 0 & 0 & 0 & 7 & \\
\hline Coal, Slag & 0 & 2 & 1 & 0 & 3 & 0 & 0 & 0 & 0 & 6 & \\
\hline Plastic & 8 & 8 & 7 & 3 & 2 & 1 & 0 & 1 & 1 & 31 & \\
\hline Paper & 0 & 0 & 1 & 0 & 0 & 0 & 0 & 0 & 0 & 1 & \\
\hline Other Miscellan. & 0 & 40 & 2 & 10 & 4 & 3 & 4 & 2 & 0 & 65 & \\
\hline Miscellaneous Total: & 8 & 50 & 12 & 13 & 9 & 10 & 4 & 3 & 1 & 110 & $2 \%$ \\
\hline Grand Totals & 1216 & 1179 & 700 & 526 & 405 & 372 & 171 & 46 & 11 & 4626 & \\
\hline$\%$ of Total & $26 \%$ & $25 \%$ & $15 \%$ & $11 \%$ & $9 \%$ & $8 \%$ & $4 \%$ & $1 \%$ & $0 \%$ & & \\
\hline
\end{tabular}


Appendix A, continued...

\begin{tabular}{|c|c|c|c|c|c|c|c|c|c|c|c|}
\hline Artifact Type & \begin{tabular}{|c|} 
Level 1 (0- \\
$10)$
\end{tabular} & Level 2 (10 & $\begin{array}{c}\text { Level } 3(20 \\
30)\end{array}$ & $\begin{array}{c}\text { Level } 4(30 \\
40)\end{array}$ & $\begin{array}{c}\text { Level } 5(40 \\
50)\end{array}$ & $\begin{array}{c}\text { Level } 6(50 \\
60)\end{array}$ & $\begin{array}{c}\text { Level } 7 \text { (60 } \\
70)\end{array}$ & $\begin{array}{c}\text { Level } 8 \text { (70 } \\
80)\end{array}$ & $\begin{array}{c}\text { Level } 9(80 \\
90)\end{array}$ & Totals & $\%$ of Total \\
\hline Lithics: & 5 & 6 & 2 & 2 & 6 & 18 & 3 & 0 & 0 & 42 & $1 \%$ \\
\hline Ceramics Total: & 38 & 107 & 78 & 84 & 63 & 58 & 29 & 25 & 5 & 487 & $12 \%$ \\
\hline Diagnostic Glass & 24 & 11 & 3 & 4 & 0 & 1 & 0 & 0 & 0 & 43 & \\
\hline Glass Fragments & 205 & 154 & 61 & 135 & 270 & 8 & 3 & 3 & 0 & 839 & \\
\hline Lamp Glass & 1 & 1 & 1 & 1 & 10 & 2 & 0 & 0 & 0 & 16 & \\
\hline Caps, Tops & 29 & 83 & 2 & 1 & 2 & 0 & 0 & 0 & 0 & 117 & \\
\hline Tableware & 0 & 0 & 0 & 0 & 0 & 0 & 0 & 0 & 0 & 0 & \\
\hline Kitchenware & 0 & 0 & 0 & 0 & 0 & 0 & 0 & 0 & 0 & 0 & \\
\hline Other Household & 0 & 0 & 0 & 0 & 0 & 0 & 0 & 0 & 0 & 0 & \\
\hline Kitchen/Household Total: & 259 & 249 & 67 & 141 & 282 & 11 & 3 & 3 & 0 & 1015 & $25 \%$ \\
\hline Window Glass & 448 & 424 & 35 & 119 & 54 & 19 & 0 & 0 & 0 & 1099 & \\
\hline Wire nails & 87 & 70 & 26 & 17 & 38 & 13 & 1 & 2 & 0 & 254 & \\
\hline Cut nails & 13 & 15 & 9 & 8 & 30 & 0 & 0 & 0 & 0 & 75 & \\
\hline Screws & 10 & 2 & 1 & 0 & 0 & 0 & 0 & 0 & 0 & 13 & \\
\hline Nuts & 0 & 0 & 0 & 0 & 0 & 0 & 0 & 0 & 0 & 0 & \\
\hline Bolts & 0 & 0 & 0 & 0 & 0 & 0 & 0 & 0 & 0 & 0 & \\
\hline Other Hardware & 1 & 1 & 1 & 0 & 1 & 1 & 0 & 1 & 0 & 6 & \\
\hline Brick, Tile & 71 & 196 & 25 & 12 & 2 & 5 & 1 & 1 & 0 & 313 & \\
\hline Mortar & 62 & 0 & 0 & 0 & 30 & 0 & 3 & 4 & 0 & 99 & \\
\hline Plaster & 2 & 0 & 0 & 0 & 0 & 0 & 2 & 0 & 0 & 4 & \\
\hline Concrete & 0 & 3 & 0 & 0 & 0 & 0 & 0 & 0 & 0 & 3 & \\
\hline Asphalt & 0 & 0 & 1 & 0 & 0 & 0 & 0 & 0 & 0 & 1 & \\
\hline Electrical Items & 7 & 6 & 0 & 2 & 2 & 0 & 0 & 0 & 0 & 17 & \\
\hline Other Constr. & 36 & 33 & 1 & 0 & 0 & 0 & 0 & 0 & 0 & 70 & \\
\hline Construction Total: & 737 & 750 & 99 & 158 & 157 & 38 & 7 & 8 & 0 & 1954 & $49 \%$ \\
\hline Buttons & 0 & 1 & 0 & 1 & 1 & 0 & 0 & 0 & 0 & 3 & \\
\hline Buckles & 0 & 1 & 0 & 0 & 0 & 0 & 0 & 0 & 0 & 1 & \\
\hline Shoe Parts & 3 & 0 & 0 & 0 & 0 & 0 & 0 & 0 & 0 & 3 & \\
\hline Other Clothing & 0 & 0 & 0 & 0 & 0 & 0 & 0 & 0 & 0 & 0 & \\
\hline Beads & 0 & 0 & 0 & 0 & 0 & 0 & 0 & 0 & 0 & 0 & \\
\hline Jewelry & 0 & 0 & 1 & 0 & 0 & 0 & 0 & 0 & 0 & 1 & \\
\hline Grooming & 0 & 0 & 0 & 0 & 0 & 0 & 0 & 0 & 0 & 0 & \\
\hline Coins & 1 & 1 & 0 & 0 & 0 & 0 & 0 & 0 & 0 & 2 & \\
\hline Other Personal & 0 & 0 & 0 & 0 & 0 & 0 & 0 & 0 & 0 & 0 & \\
\hline Clothing/Personal Total: & 4 & 3 & 1 & 1 & 1 & 0 & 0 & 0 & 0 & 10 & $0 \%$ \\
\hline Toys & 0 & 0 & 0 & 0 & 0 & 0 & 0 & 0 & 0 & 0 & \\
\hline Writing Material & 0 & 0 & 0 & 0 & 0 & 0 & 0 & 0 & 0 & 0 & \\
\hline Other Activities & 1 & 0 & 1 & 0 & 0 & 1 & 0 & 0 & 0 & 3 & \\
\hline Activity Total: & 1 & 0 & 1 & 0 & 0 & 1 & 0 & 0 & 0 & 3 & $0 \%$ \\
\hline Shell casings & 1 & 1 & 0 & 0 & 0 & 0 & 0 & 0 & 0 & 2 & \\
\hline Other arms & 1 & 1 & 1 & 0 & 0 & 1 & 0 & 0 & 0 & 4 & \\
\hline Arms Total: & 2 & 2 & 1 & 0 & 0 & 1 & 0 & 0 & 0 & 6 & $0 \%$ \\
\hline Tools & 0 & 0 & 0 & 0 & 0 & 0 & 0 & 0 & 0 & 0 & \\
\hline Wire & 2 & 2 & 4 & 5 & 0 & 0 & 0 & 0 & 0 & 13 & \\
\hline Horseshoes & 0 & 0 & 0 & 0 & 0 & 0 & 0 & 0 & 0 & 0 & \\
\hline Machinery & 0 & 0 & 0 & 0 & 0 & 0 & 0 & 0 & 0 & 0 & \\
\hline Other Workshop & 1 & 1 & 1 & 0 & 0 & 0 & 0 & 0 & 0 & 3 & \\
\hline Barn/Workshop Total: & 3 & 3 & 5 & 5 & 0 & 0 & 0 & 0 & 0 & 16 & $0 \%$ \\
\hline Copper scrap & 1 & 0 & 0 & 0 & 0 & 0 & 0 & 0 & 0 & 1 & \\
\hline Iron scrap & 78 & 67 & 53 & 198 & 10 & 4 & 0 & 3 & 0 & 413 & \\
\hline Other Metal & 3 & 0 & 1 & 0 & 0 & 0 & 0 & 0 & 0 & 4 & \\
\hline Unident'fd Metal & 6 & 1 & 0 & 0 & 1 & 4 & 0 & 0 & 0 & 12 & \\
\hline Metal Total: & 88 & 68 & 54 & 198 & 11 & 8 & 0 & 3 & 0 & 430 & $11 \%$ \\
\hline Seeds, Pits & 0 & 0 & 0 & 0 & 0 & 0 & 0 & 0 & 0 & 0 & \\
\hline Coal, Slag & 0 & 3 & 0 & 0 & 0 & 7 & 0 & 0 & 0 & 10 & \\
\hline Plastic & 10 & 1 & 0 & 1 & 1 & 1 & 0 & 0 & 0 & 14 & \\
\hline Paper & 0 & 0 & 0 & 0 & 0 & 0 & 0 & 0 & 0 & 0 & \\
\hline Other Miscellan. & 10 & 20 & 1 & 0 & 0 & 1 & 0 & 0 & 0 & 32 & \\
\hline Miscellaneous Total: & 20 & 24 & 1 & 1 & 1 & 9 & 0 & 0 & 0 & 56 & $1 \%$ \\
\hline Grand Totals & 1157 & 1212 & 309 & 590 & 521 & 144 & 42 & 39 & 5 & 4019 & \\
\hline$\%$ of Total & $29 \%$ & $30 \%$ & $8 \%$ & $15 \%$ & $13 \%$ & $4 \%$ & $1 \%$ & $1 \%$ & $0 \%$ & & \\
\hline
\end{tabular}


Appendix A, continued...

\begin{tabular}{|c|c|c|c|c|c|c|c|c|c|c|}
\hline Artifact Type & \begin{tabular}{|c|} 
Level $1(0$ \\
$10)$ \\
\end{tabular} & $\begin{array}{c}\text { Level } 2 \text { (10- } \\
20)\end{array}$ & \begin{tabular}{|c|} 
Level $3(20-1$ \\
$30)$
\end{tabular} & $\begin{array}{c}\text { Level } 4 \text { (30- } \\
40)\end{array}$ & $\begin{array}{c}\text { Level } 5(40-1 \\
50)\end{array}$ & \begin{tabular}{|c|} 
Level 6 (50- \\
$60)$ \\
\end{tabular} & \begin{tabular}{|c|} 
Level $7(60$ \\
$70)$
\end{tabular} & $\begin{array}{c}\text { Level } 8 \text { (70 } \\
80)\end{array}$ & Totals & $\%$ of Total \\
\hline Lithics: & 1 & 4 & 2 & 1 & 1 & 0 & 0 & 0 & 9 & $1 \%$ \\
\hline Ceramics Total: & 7 & 27 & 28 & 7 & 8 & 8 & 2 & 2 & 89 & $7 \%$ \\
\hline Diagnostic Glass & 8 & 7 & 3 & 0 & 1 & 0 & 0 & 0 & 19 & \\
\hline Glass Fragments & 115 & 116 & 48 & 8 & 36 & 2 & 1 & 1 & 327 & \\
\hline Lamp Glass & 4 & 0 & 0 & 0 & 0 & 0 & 2 & 0 & 6 & \\
\hline Caps, Tops & 25 & 18 & 3 & 0 & 0 & 0 & 0 & 1 & 47 & \\
\hline Tableware & 0 & 0 & 0 & 0 & 0 & 0 & 0 & 0 & 0 & \\
\hline Kitchenware & 0 & 0 & 0 & 0 & 0 & 0 & 0 & 0 & 0 & \\
\hline Other Household & 0 & 0 & 0 & 0 & 0 & 0 & 0 & 0 & 0 & \\
\hline Kitchen/Household Total: & 152 & 141 & 54 & 8 & 37 & 2 & 3 & 2 & 399 & $33 \%$ \\
\hline Window Glass & 10 & 8 & 125 & 21 & 12 & 4 & 8 & 3 & 191 & \\
\hline Wire nails & 9 & 10 & 5 & 1 & 3 & 2 & 0 & 2 & 32 & \\
\hline Cut nails & 3 & 6 & 2 & 4 & 1 & 1 & 0 & 0 & 17 & \\
\hline Screws & 0 & 1 & 0 & 0 & 1 & 0 & 0 & 0 & 2 & \\
\hline Nuts & 0 & 0 & 1 & 0 & 0 & 1 & 0 & 0 & 2 & \\
\hline Bolts & 0 & 0 & 0 & 0 & 0 & 0 & 0 & 0 & 0 & \\
\hline Other Hardware & 2 & 0 & 0 & 0 & 0 & 0 & 0 & 0 & 2 & \\
\hline Brick, Tile & 18 & 38 & 21 & 22 & 20 & 8 & 1 & 0 & 128 & \\
\hline Mortar & 10 & 0 & 1 & 4 & 7 & 43 & 0 & 0 & 65 & \\
\hline Plaster & 0 & 0 & 0 & 0 & 0 & 0 & 0 & 0 & 0 & \\
\hline Concrete & 0 & 0 & 2 & 3 & 0 & 0 & 0 & 0 & 5 & \\
\hline Asphalt & 0 & 0 & 0 & 0 & 0 & 0 & 0 & 0 & 0 & \\
\hline Electrical Items & 3 & 6 & 0 & 0 & 0 & 0 & 0 & 0 & 9 & \\
\hline Other Constr. & 13 & 15 & 26 & 1 & 51 & 21 & 0 & 0 & 127 & \\
\hline Construction Total: & 68 & 84 & 183 & 56 & 95 & 80 & 9 & 5 & 580 & $48 \%$ \\
\hline Buttons & 0 & 0 & 1 & 0 & 0 & 0 & 0 & 0 & 1 & \\
\hline Buckles & 0 & 0 & 0 & 0 & 0 & 0 & 0 & 0 & 0 & \\
\hline Shoe Parts & 0 & 0 & 0 & 0 & 0 & 0 & 0 & 0 & 0 & \\
\hline Other Clothing & 2 & 0 & 0 & 0 & 0 & 0 & 0 & 0 & 2 & \\
\hline Beads & 0 & 0 & 0 & 0 & 0 & 0 & 0 & 0 & 0 & \\
\hline Jewelry & 0 & 0 & 0 & 0 & 0 & 0 & 0 & 0 & 0 & \\
\hline Grooming & 0 & 0 & 0 & 0 & 0 & 0 & 0 & 0 & 0 & \\
\hline Coins & 2 & 1 & 0 & 0 & 0 & 0 & 0 & 0 & 3 & \\
\hline Other Personal & 0 & 0 & 0 & 0 & 0 & 0 & 0 & 0 & 0 & \\
\hline Clothing/Personal Total: & 4 & 1 & 1 & 0 & 0 & 0 & 0 & 0 & 6 & $0 \%$ \\
\hline Toys & 0 & 0 & 0 & 1 & 0 & 0 & 0 & 0 & 1 & \\
\hline Writing Material & 0 & 1 & 0 & 0 & 0 & 0 & 0 & 0 & 1 & \\
\hline Other Activities & 0 & 1 & 0 & 0 & 0 & 0 & 0 & 1 & 2 & \\
\hline Activity Total: & 0 & 2 & 0 & 1 & 0 & 0 & 0 & 1 & 4 & $0 \%$ \\
\hline Shell casings & 0 & 0 & 0 & 0 & 0 & 0 & 0 & 0 & 0 & \\
\hline Other arms & 0 & 1 & 0 & 0 & 0 & 0 & 0 & 0 & 1 & \\
\hline Arms Total: & 0 & 1 & 0 & 0 & 0 & 0 & 0 & 0 & 1 & $0 \%$ \\
\hline Tools & 0 & 0 & 0 & 0 & 0 & 0 & 0 & 0 & 0 & \\
\hline Wire & 2 & 0 & 0 & 0 & 0 & 0 & 0 & 0 & 2 & \\
\hline Horseshoes & 0 & 0 & 1 & 0 & 0 & 0 & 0 & 0 & 1 & \\
\hline Machinery & 0 & 0 & 0 & 0 & 0 & 0 & 0 & 0 & 0 & \\
\hline Other Workshop & 0 & 0 & 0 & 0 & 0 & 0 & 0 & 0 & 0 & \\
\hline Barn/Workshop Total: & 2 & 0 & 1 & 0 & 0 & 0 & 0 & 0 & 3 & $0 \%$ \\
\hline Copper scrap & 0 & 1 & 0 & 0 & 0 & 0 & 0 & 1 & 2 & \\
\hline Iron scrap & 17 & 15 & 32 & 17 & 11 & 3 & 0 & 0 & 95 & \\
\hline Other Metal & 0 & 0 & 2 & 1 & 0 & 0 & 0 & 0 & 3 & \\
\hline Unident'fd Metal & 0 & 0 & 1 & 0 & 0 & 0 & 0 & 0 & 1 & \\
\hline Metal Total: & 17 & 16 & 35 & 18 & 11 & 3 & 0 & 1 & 101 & $8 \%$ \\
\hline Seeds, Pits & 0 & 0 & 0 & 0 & 0 & 0 & 0 & 0 & 0 & \\
\hline Coal, Slag & 0 & 0 & 4 & 0 & 0 & 0 & 0 & 0 & 4 & \\
\hline Plastic & 17 & 1 & 1 & 0 & 0 & 0 & 0 & 0 & 19 & \\
\hline Paper & 0 & 0 & 0 & 0 & 0 & 0 & 0 & 0 & 0 & \\
\hline Other Miscellan. & 2 & 0 & 0 & 0 & 0 & 0 & 0 & 0 & 2 & \\
\hline Miscellaneous Total: & 19 & 1 & 5 & 0 & 0 & 0 & 0 & 0 & 25 & $2 \%$ \\
\hline Grand Totals & 270 & 277 & 309 & 91 & 152 & 93 & 14 & 11 & 1217 & \\
\hline$\%$ of Total & $22 \%$ & $23 \%$ & $25 \%$ & $7 \%$ & $12 \%$ & $8 \%$ & $1 \%$ & $1 \%$ & & \\
\hline
\end{tabular}


Appendix A, continued...

\begin{tabular}{|c|c|c|c|c|c|c|c|c|c|c|c|}
\hline Artifacts & \begin{tabular}{|c|} 
Level $1(0$ \\
$10)$
\end{tabular} & $\begin{array}{l}\text {-evel } 2 \text { (10- } \\
20)\end{array}$ & $\begin{array}{c}\text { Level } 3(20- \\
30)\end{array}$ & \begin{tabular}{|c|} 
Level $4(30-$ \\
$40)$
\end{tabular} & \begin{tabular}{|c|} 
Level $5(40$ \\
$50)$
\end{tabular} & $\begin{array}{c}\text { Level } 6(50- \\
60)\end{array}$ & $\begin{array}{c}\text { Level } 7(60- \\
70)\end{array}$ & $\begin{array}{c}\text { Level } 8(70- \\
80)\end{array}$ & $\begin{array}{c}\text { Level } 9(80 \\
90)\end{array}$ & Totals & $\%$ of Total \\
\hline Lithics: & 9 & 13 & 10 & 7 & 13 & 25 & 4 & 1 & 0 & 82 & $1 \%$ \\
\hline Ceramics Total: & 98 & 209 & 156 & 140 & 107 & 100 & 44 & 30 & 5 & 889 & $10 \%$ \\
\hline Diagnostic Glass & 38 & 32 & 14 & 8 & 12 & 6 & 11 & 0 & 1 & 122 & \\
\hline Glass Fragments & 465 & 477 & 270 & 246 & 382 & 76 & 42 & 18 & 2 & 1978 & \\
\hline Lamp Glass & 38 & 48 & 5 & 16 & 16 & 3 & 8 & 0 & 0 & 134 & \\
\hline Caps, Tops & 75 & 120 & 26 & 11 & 10 & 8 & 5 & 1 & 0 & 256 & \\
\hline Tableware & 0 & 0 & 0 & 0 & 0 & 1 & 0 & 0 & 0 & 1 & \\
\hline Kitchenware & 0 & 0 & 1 & 0 & 0 & 0 & 0 & 0 & 0 & 1 & \\
\hline Other Household & 5 & 1 & 1 & 5 & 0 & 0 & 0 & 0 & 0 & 12 & \\
\hline Kitchen/Household Total: & 621 & 678 & 317 & 286 & 420 & 94 & 66 & 19 & 3 & 2504 & $27 \%$ \\
\hline Window Glass & 784 & 664 & 279 & 218 & 133 & 84 & 33 & 9 & 5 & 2209 & \\
\hline Wire nails & 291 & 236 & 179 & 112 & 108 & 62 & 33 & 10 & 2 & 1033 & \\
\hline Cut nails & 18 & 29 & 18 & 21 & 37 & 11 & 0 & 1 & 1 & 136 & \\
\hline Screws & 23 & 6 & 3 & 0 & 1 & 0 & 0 & 0 & 0 & 33 & \\
\hline Nuts & 1 & 0 & 1 & 0 & 0 & 1 & 0 & 0 & 0 & 3 & \\
\hline Bolts & 1 & 0 & 0 & 0 & 0 & 0 & 0 & 0 & 0 & 1 & \\
\hline Other Hardware & 21 & 9 & 5 & 0 & 1 & 2 & 0 & 1 & 0 & 39 & \\
\hline Brick, Tile & 139 & 27 & 75 & 48 & 41 & 32 & 8 & 1 & 0 & 371 & \\
\hline Mortar & 75 & 2 & 3 & 5 & 39 & 63 & 6 & 6 & 0 & 199 & \\
\hline Plaster & 2 & 0 & 0 & 0 & 0 & 0 & 2 & 0 & 0 & 4 & \\
\hline Concrete & 0 & 3 & 2 & 4 & 0 & 0 & 0 & 0 & 0 & 9 & \\
\hline Asphalt & 0 & 0 & 2 & 0 & 0 & 0 & 0 & 0 & 0 & 2 & \\
\hline Electrical Items & 101 & 71 & 8 & 6 & 2 & 0 & 0 & 0 & 0 & 188 & \\
\hline Other Constr. & 59 & 152 & 43 & 39 & 81 & 29 & 0 & 3 & 0 & 406 & \\
\hline Construction Total: & 1515 & 1199 & 618 & 453 & 443 & 284 & 82 & 31 & 8 & 4633 & $50 \%$ \\
\hline Buttons & 0 & 3 & 1 & 2 & 2 & 0 & 0 & 0 & 0 & 8 & \\
\hline Buckles & 0 & 1 & 0 & 0 & 0 & 0 & 0 & 0 & 0 & 1 & \\
\hline Shoe Parts & 3 & 1 & 0 & 0 & 0 & 0 & 0 & 0 & 0 & 4 & \\
\hline Other Clothing & 3 & 0 & 0 & 0 & 0 & 0 & 0 & 0 & 0 & 3 & \\
\hline Beads & 0 & 0 & 0 & 0 & 1 & 0 & 1 & 0 & 0 & 2 & \\
\hline Jewelry & 0 & 0 & 1 & 0 & 0 & 0 & 0 & 0 & 0 & 1 & \\
\hline Grooming & 0 & 2 & 0 & 0 & 0 & 0 & 0 & 0 & 0 & 2 & \\
\hline Coins & 4 & 3 & 1 & 0 & 0 & 0 & 0 & 0 & 0 & 8 & \\
\hline Other Personal & 0 & 0 & 0 & 1 & 0 & 1 & 1 & 0 & 0 & 3 & \\
\hline Clothing/Personal Total: & 10 & 10 & 3 & 3 & 3 & 1 & 2 & 0 & 0 & 32 & $0 \%$ \\
\hline Toys & 0 & 1 & 0 & 2 & 0 & 0 & 0 & 0 & 0 & 3 & \\
\hline Writing Material & 0 & 1 & 0 & 1 & 0 & 1 & 0 & 0 & 0 & 3 & \\
\hline Other Activities & 1 & 1 & 1 & 0 & 1 & 1 & 0 & 2 & 0 & 7 & \\
\hline Activity Total: & 1 & 3 & 1 & 3 & 1 & 2 & 0 & 2 & 0 & 13 & $0 \%$ \\
\hline Shell casings & 1 & 1 & 0 & 0 & 0 & 0 & 0 & 0 & 0 & 2 & \\
\hline Other arms & 1 & 2 & 2 & 0 & 0 & 1 & 0 & 0 & 0 & 6 & \\
\hline Arms Total: & 2 & 3 & 2 & 0 & 0 & 1 & 0 & 0 & 0 & 8 & $0 \%$ \\
\hline Tools & 0 & 0 & 3 & 1 & 3 & 0 & 0 & 0 & 0 & 7 & \\
\hline Wire & 22 & 16 & 5 & 15 & 11 & 3 & 1 & 1 & 0 & 74 & \\
\hline Horseshoes & 0 & 0 & 1 & 0 & 0 & 0 & 0 & 0 & 0 & 1 & \\
\hline Machinery & 0 & 1 & 1 & 0 & 0 & 1 & 0 & 0 & 0 & 3 & \\
\hline Other Workshop & 22 & 6 & 3 & 1 & 1 & 0 & 2 & 0 & 0 & 35 & \\
\hline Barn/Workshop Total: & 44 & 23 & 13 & 17 & 15 & 4 & 3 & 1 & 0 & 120 & $1 \%$ \\
\hline Copper scrap & 51 & 4 & 10 & 0 & 2 & 23 & 1 & 1 & 0 & 92 & \\
\hline Iron scrap & 173 & 119 & 112 & 227 & 26 & 15 & 7 & 3 & 2 & 684 & \\
\hline Other Metal & 9 & 8 & 6 & 4 & 0 & 0 & 0 & 0 & 0 & 27 & \\
\hline Unident'fd Metal & 9 & 4 & 3 & 2 & 1 & 6 & 1 & 1 & 0 & 27 & \\
\hline Metal Total: & 242 & 135 & 131 & 233 & 29 & 44 & 9 & 5 & 2 & 830 & $9 \%$ \\
\hline Seeds, Pits & 0 & 0 & 1 & 0 & 0 & 6 & 0 & 0 & 0 & 7 & \\
\hline Coal, Slag & 0 & 5 & 5 & 0 & 3 & 7 & 0 & 0 & 0 & 20 & \\
\hline Plastic & 35 & 10 & 8 & 4 & 3 & 2 & 0 & 1 & 1 & 64 & \\
\hline Paper & 0 & 0 & 1 & 0 & 0 & 0 & 0 & 0 & 0 & 1 & \\
\hline Other Miscellan. & 12 & 60 & 3 & 10 & 4 & 4 & 4 & 2 & 0 & 99 & \\
\hline Miscellaneous Total: & 47 & 75 & 18 & 14 & 10 & 19 & 4 & 3 & 1 & 191 & $2 \%$ \\
\hline Grand Totals & 2589 & 2348 & 1269 & 1156 & 1041 & 574 & 214 & 92 & 19 & 9302 & \\
\hline$\%$ of Total & $28 \%$ & $25 \%$ & $14 \%$ & $12 \%$ & $11 \%$ & $6 \%$ & $2 \%$ & $1 \%$ & $0 \%$ & & \\
\hline
\end{tabular}



Appendix B

Ceramics 
Appendix B

\begin{tabular}{|c|c|c|c|c|c|c|c|c|c|c|c|}
\hline & Ceramic Type & $\begin{array}{c}\text { Level } 1 \\
(0-10)\end{array}$ & $\begin{array}{l}\text { Level } 2 \\
(10-20) \\
\end{array}$ & $\begin{array}{l}\text { Level } 3 \\
(20-30) \\
\end{array}$ & $\begin{array}{l}\text { Level } 4 \\
(30-40) \\
\end{array}$ & $\begin{array}{l}\text { Level } 5 \\
(40-50) \\
\end{array}$ & $\begin{array}{l}\text { Level } 6 \\
(50-60)\end{array}$ & $\begin{array}{l}\text { Level } 7 \\
(60-70)\end{array}$ & $\begin{array}{l}\text { Level } 8 \\
(70-80) \\
\end{array}$ & $\begin{array}{l}\text { Level } 9 \\
(80-90)\end{array}$ & Totals \\
\hline$G$ & & & & & & & & & & & \\
\hline & & & & & & & & & & & \\
\hline 0 & & & & & & & & & & & \\
\hline L & & & & & & & & & & & \\
\hline A & & & & & & & & & & & \\
\hline D & Goliad & 4 & 20 & 17 & 11 & 7 & 7 & 0 & 1 & 0 & 67 \\
\hline B & & & & & & & & & & & \\
\hline U & & & & & & & & & & & \\
\hline $\mathrm{N}$ & Tonala & 0 & 0 & 0 & 1 & 0 & 0 & 0 & 0 & 0 & 1 \\
\hline I & Red Paste & 0 & 0 & 0 & 0 & 1 & 0 & 0 & 0 & 0 & 1 \\
\hline $\begin{array}{l}S \\
H\end{array}$ & Black & 0 & 0 & 0 & 0 & 0 & 0 & 0 & 0 & 0 & 0 \\
\hline E & Valero & 0 & 1 & 0 & 0 & 0 & 0 & 0 & 0 & 0 & 1 \\
\hline D & Flower Pot & 11 & 19 & 1 & 1 & 0 & 1 & 0 & 0 & 0 & 33 \\
\hline u & & & & & & & & & & & \\
\hline N & & & & & & & & & & & \\
\hline G & & & & & & & & & & & \\
\hline $\mathrm{L}$ & & & & & & & & & & & \\
\hline $\begin{array}{l}A \\
7\end{array}$ & & & & & & & & & & & \\
\hline $\mathrm{E}$ & & & & & & & & & & & \\
\hline D & Undecorated & 6 & 0 & 0 & 0 & 0 & 0 & 0 & 0 & 0 & 6 \\
\hline & & & & & & & & & & & \\
\hline G & Olive Jar & 0 & 0 & 0 & 0 & 0 & 0 & 0 & 0 & 0 & 0 \\
\hline $\mathrm{L}$ & Sandy Paste & 5 & 7 & 7 & 7 & 5 & 6 & 2 & 1 & 0 & 40 \\
\hline $\begin{array}{l}\text { L A } \\
\text { F } 7\end{array}$ & Galera & 3 & 0 & 7 & 6 & 5 & 6 & 3 & 0 & 0 & 30 \\
\hline $\begin{array}{ll}E Z \\
A E\end{array}$ & Red-brown & 0 & 0 & 1 & 0 & 0 & 0 & 0 & 0 & 0 & 1 \\
\hline D D & Other & 2 & 0 & 0 & 0 & 1 & 0 & 0 & 0 & 0 & 3 \\
\hline & Undecorated & 4 & 1 & 4 & 2 & 4 & 8 & 2 & 1 & 0 & 26 \\
\hline & San Augustin & 0 & 1 & 0 & 1 & 1 & 0 & 0 & 0 & 0 & 3 \\
\hline & Blue on White & 2 & 0 & 1 & 0 & 0 & 3 & 1 & 0 & 0 & 7 \\
\hline & Huejotzingo & 1 & 0 & 1 & 0 & 2 & 0 & 0 & 0 & 0 & 4 \\
\hline$T$ & San Elizario & 1 & 1 & 0 & 0 & 0 & 1 & 0 & 0 & 0 & 3 \\
\hline $\begin{array}{l}\mathrm{I} \\
\mathbf{N}\end{array}$ & $\begin{array}{l}\text { Thin Brown, Black, \& } \\
\text { Blue }\end{array}$ & 0 & 0 & 0 & 0 & 0 & 0 & 0 & 0 & 0 & 0 \\
\hline$G$ & Monterey & 2 & 0 & 0 & 4 & 0 & 0 & 0 & 0 & 0 & 6 \\
\hline L & $\begin{array}{l}\text { Puebla Blue on } \\
\text { White II }\end{array}$ & 0 & 0 & 0 & 0 & 0 & 0 & 0 & 0 & 0 & 0 \\
\hline $\begin{array}{l}\mathrm{Z} \\
\mathrm{E}\end{array}$ & Other & 3 & 0 & 1 & 0 & 1 & 0 & 0 & 0 & 0 & 5 \\
\hline D & Faience & 0 & 1 & 1 & 1 & 0 & 0 & 0 & 0 & 0 & 3 \\
\hline & Undecorated & 4 & 11 & 2 & 9 & 5 & 0 & 4 & 0 & 0 & 35 \\
\hline & Transfer & 1 & 0 & 3 & 1 & 0 & 0 & 0 & 0 & 0 & 5 \\
\hline & Hand Painted & 0 & 2 & 0 & 2 & 3 & 1 & 1 & 0 & 0 & 9 \\
\hline w & Spatter/Sponge & 0 & 0 & 1 & 1 & 0 & 0 & 0 & 0 & 0 & 2 \\
\hline H & Edged & 0 & 0 & 0 & 0 & 0 & 1 & 0 & 0 & 0 & 1 \\
\hline $\mathrm{T}$ & Banded Slip & 1 & 3 & 2 & 1 & 1 & 0 & 0 & 0 & 0 & 8 \\
\hline $\mathrm{E}$ & Plain Colored & 1 & 0 & 0 & 0 & 0 & 0 & 0 & 0 & 0 & 1 \\
\hline w & Other & 0 & 0 & 0 & 0 & 0 & 0 & 0 & 0 & 0 & 0 \\
\hline A & Porcelain & 0 & 0 & 1 & 0 & 0 & 0 & 0 & 0 & 0 & 1 \\
\hline $\begin{array}{l}R \\
E\end{array}$ & Porcelain, European & 1 & 6 & 0 & 0 & 0 & 0 & 0 & 0 & 0 & 7 \\
\hline $\mathrm{s}$ & Porcelain, Oriental & 1 & 0 & 0 & 0 & 0 & 0 & 0 & 0 & 0 & 1 \\
\hline s & & & & & & & & & & & \\
\hline$T$ & & & & & & & & & & & \\
\hline $\mathrm{N}$ & & & & & & & & & & & \\
\hline E & & & & & & & & & & & \\
\hline w & Salt Glazed & 0 & 1 & 0 & 0 & 0 & 0 & 0 & 0 & 0 & 1 \\
\hline $\begin{array}{l}\text { A } \\
\mathbf{R}\end{array}$ & Bristol Glaze & 0 & 0 & 0 & 0 & 0 & 0 & 0 & 0 & 0 & 0 \\
\hline $\mathrm{E}$ & Other & 0 & 1 & 0 & 1 & 0 & 0 & 0 & 0 & 0 & 2 \\
\hline & & & & & & & & & & & \\
\hline B & & & & & & & & & & & \\
\hline I & & & & & & & & & & & \\
\hline s & & & & & & & & & & & \\
\hline $\begin{array}{l}\mathbf{Q} \\
\mathbf{U}\end{array}$ & & & & & & & & & & & \\
\hline $\mathrm{E}$ & Painted & 0 & 0 & 0 & 0 & 0 & 0 & 0 & 0 & 0 & 0 \\
\hline & & & & & & & & & & & \\
\hline & & 53 & 75 & 50 & 49 & 36 & 34 & 13 & 3 & 0 & 313 \\
\hline
\end{tabular}


Appendix B, continued...

\begin{tabular}{|c|c|c|c|c|c|c|c|c|c|c|c|}
\hline & Ceramic Type & $\begin{array}{c}\text { Level } 1 \\
(0-10)\end{array}$ & $\begin{array}{c}\text { Level } 2 \\
(10-20)\end{array}$ & $\begin{array}{l}\text { Level } 3 \\
(20-30)\end{array}$ & $\begin{array}{l}\text { Level } 4 \\
(30-40)\end{array}$ & $\begin{array}{l}\text { Level } 5 \\
(40-50)\end{array}$ & $\begin{array}{l}\text { Level } 6 \\
(50-60)\end{array}$ & $\begin{array}{l}\text { Level } 7 \\
(60-70)\end{array}$ & $\begin{array}{l}\text { Level } 8 \\
(70-80)\end{array}$ & $\begin{array}{l}\text { Level } 9 \\
(80-90)\end{array}$ & Totals \\
\hline \\
\hline \multirow{2}{*}{\multicolumn{11}{|c|}{$\begin{array}{l}\mathrm{G} \\
0\end{array}$}} & \\
\hline & & & & & & & & & & & \\
\hline \multicolumn{12}{|l|}{$\mathbf{L}$} \\
\hline \multicolumn{12}{|l|}{ I } \\
\hline D & Goliad & 5 & 16 & 13 & 25 & 26 & 24 & 11 & 13 & 4 & 137 \\
\hline \multicolumn{12}{|l|}{ B } \\
\hline \multicolumn{12}{|l|}{$\mathbf{U}$} \\
\hline \multicolumn{12}{|l|}{$\mathbf{R}$} \\
\hline \multirow{5}{*}{$\begin{array}{l}\mathbf{N} \\
\mathrm{I} \\
\mathrm{S} \\
\mathrm{H} \\
\mathrm{E} \\
\mathrm{D} \\
\end{array}$} & Tonala & 1 & 1 & 0 & 0 & 0 & 0 & 0 & 0 & 0 & 2 \\
\hline & Red Paste & 0 & 0 & 0 & 0 & 0 & 0 & 0 & 0 & 0 & 0 \\
\hline & Black & 0 & 0 & 0 & 0 & 1 & 0 & 0 & 0 & 0 & 1 \\
\hline & Valero & 0 & 0 & 2 & 3 & 2 & 1 & 3 & 0 & 0 & 11 \\
\hline & Flower Pot & 1 & 0 & 0 & 0 & 0 & 1 & 0 & 0 & 0 & 2 \\
\hline \multicolumn{12}{|l|}{$\mathbf{u}$} \\
\hline \multicolumn{12}{|l|}{$\mathbf{N}$} \\
\hline \multicolumn{12}{|l|}{ G } \\
\hline $\mathbf{L}$ & \multicolumn{11}{|c|}{$\mathrm{L}$} \\
\hline \multicolumn{12}{|l|}{$\begin{array}{l}A \\
Z\end{array}$} \\
\hline $\mathrm{E}$ & & & & & & & & & & & \\
\hline D & Undecorated & 0 & 0 & 0 & 0 & 0 & 0 & 0 & 0 & 0 & 0 \\
\hline$G$ & Olive lar & 0 & 0 & 0 & 0 & 0 & 1 & 0 & 0 & 0 & 1 \\
\hline L & Sandy Paste & 2 & 7 & $\frac{0}{10}$ & $\frac{0}{10}$ & 5 & $\frac{1}{7}$ & 0 & 0 & 0 & $\frac{1}{46}$ \\
\hline L A & Galera & 3 & 5 & 8 & 7 & 3 & 6 & 2 & 0 & 0 & 34 \\
\hline A E & Red-brown & 0 & 0 & 0 & 0 & 0 & 0 & 0 & 0 & 0 & 0 \\
\hline D D & Other & 0 & 1 & 0 & 0 & 0 & 0 & 0 & 1 & 0 & 2 \\
\hline & Undecorated & 1 & 3 & 3 & 3 & 4 & 2 & 1 & 3 & 0 & 20 \\
\hline & San Augustin & 0 & 0 & 0 & 0 & 2 & 0 & 0 & 0 & 0 & 2 \\
\hline & Blue on White & 0 & 2 & 1 & 2 & 3 & 2 & 1 & 3 & 1 & 15 \\
\hline & Huejotzingo & 0 & 0 & 2 & 2 & 0 & 0 & 0 & 1 & 0 & 5 \\
\hline $\mathbf{T}$ & San Elizario & 0 & 0 & 2 & 3 & 2 & 3 & 1 & 1 & 0 & 12 \\
\hline $\mathrm{N}$ & $\begin{array}{l}\text { Thin Brown, Black, \& } \\
\text { Blue }\end{array}$ & 0 & 1 & 0 & 1 & 0 & 0 & 0 & 0 & 0 & 2 \\
\hline G & Monterey & 0 & 0 & 0 & 1 & 1 & 0 & 0 & 0 & 0 & 2 \\
\hline $\begin{array}{l}\mathrm{L} \\
\mathrm{A} \\
\mathbf{Z}\end{array}$ & $\begin{array}{l}\text { Puebla Blue on } \\
\text { White II }\end{array}$ & 0 & 0 & 0 & 0 & 1 & 0 & 1 & 0 & 0 & 2 \\
\hline$E$ & Other & 0 & 1 & 1 & 1 & 0 & 1 & 2 & 0 & 0 & 6 \\
\hline D & Faience & 0 & 0 & 1 & 0 & 0 & 0 & 0 & 0 & 0 & 1 \\
\hline & Undecorated & 6 & 26 & 15 & 14 & 7 & 4 & 1 & 2 & 0 & 75 \\
\hline & Transfer & 5 & 8 & 4 & 4 & 1 & 1 & 1 & 0 & 0 & 24 \\
\hline & Hand Painted & 1 & 9 & 3 & 0 & 2 & 0 & 0 & 1 & 0 & 16 \\
\hline w & Spatter/Sponge & 3 & 1 & 0 & 0 & 0 & 0 & 0 & 0 & 0 & 4 \\
\hline $\begin{array}{l}\mathrm{H} \\
\mathbf{I}\end{array}$ & Edged & 1 & 5 & 2 & 1 & 1 & 0 & 0 & 0 & 0 & 10 \\
\hline $\mathbf{T}$ & Banded Slip & 3 & 9 & 9 & 2 & 0 & 4 & 0 & 0 & 0 & 27 \\
\hline$E$ & Plain Colored & 2 & 7 & 0 & 0 & 0 & 0 & 0 & 0 & 0 & 9 \\
\hline W & Other & 2 & 0 & 0 & 5 & 0 & 0 & 0 & 0 & 0 & 7 \\
\hline $\begin{array}{l}\mathbf{A} \\
\mathbf{B}\end{array}$ & Porcelain & 0 & 0 & 0 & 0 & 0 & 0 & 0 & 0 & 0 & 0 \\
\hline$E$ & Porcelain, European & 0 & 5 & 0 & 0 & 0 & 0 & 0 & 0 & 0 & 5 \\
\hline $\mathbf{s}$ & Porcelain, Oriental & 0 & 0 & 0 & 0 & 1 & 0 & 0 & 0 & 0 & 1 \\
\hline s & & & & & & & & & & & \\
\hline T & & & & & & & & & & & \\
\hline $\mathrm{N}$ & & & & & & & & & & & \\
\hline E & & & & & & & & & & & \\
\hline $\begin{array}{l}\text { W } \\
\text { A }\end{array}$ & Salt Glazed & 1 & 0 & 1 & 0 & 0 & 1 & 0 & 0 & 0 & 3 \\
\hline $\begin{array}{l}\mathbf{A} \\
\mathbf{R}\end{array}$ & Bristol Glaze & 0 & 0 & 0 & 0 & 1 & 0 & 0 & 0 & 0 & 1 \\
\hline $\mathrm{E}$ & Other & 1 & 0 & 1 & 0 & 0 & 0 & 0 & 0 & 0 & 2 \\
\hline B & & & & & & & & & & & \\
\hline $\mathbf{I}$ & & & & & & & & & & & \\
\hline s & & & & & & & & & & & \\
\hline $\mathbf{u}$ & & & & & & & & & & & \\
\hline $\mathrm{E}$ & Painted & 0 & 0 & 0 & 0 & 0 & 0 & 0 & 0 & 0 & 0 \\
\hline & & 38 & 107 & 78 & 84 & 63 & 58 & 29 & 25 & 5 & 487 \\
\hline
\end{tabular}


Appendix B, continued...

\begin{tabular}{|c|c|c|c|c|c|c|c|c|c|c|c|}
\hline & Ceramic Type & $\begin{array}{c}\text { Level 1 } \\
(0-10)\end{array}$ & $\begin{array}{l}\text { Level } 2 \\
(10-20)\end{array}$ & \begin{tabular}{l|} 
Level 3 \\
$(20-30)$
\end{tabular} & $\begin{array}{l}\text { Level } 4 \\
(30-40)\end{array}$ & $\begin{array}{l}\text { Level } 5 \\
(40-50)\end{array}$ & $\begin{array}{l}\text { Level } 6 \\
(50-60)\end{array}$ & $\begin{array}{l}\text { Level } 7 \\
(60-70)\end{array}$ & $\begin{array}{l}\text { Level } 8 \\
(70-80)\end{array}$ & $\begin{array}{l}\text { Level } 9 \\
(80-90)\end{array}$ & Totals \\
\hline \multirow{2}{*}{\multicolumn{12}{|c|}{$\begin{array}{l}G \\
0\end{array}$}} \\
\hline & & & & & & & & & & & \\
\hline \multicolumn{12}{|l|}{ L } \\
\hline \multicolumn{12}{|l|}{ I } \\
\hline D & Goliad & 1 & 0 & 2 & 0 & 0 & 2 & 0 & 1 & 0 & 6 \\
\hline \multicolumn{12}{|l|}{ B } \\
\hline \multirow{2}{*}{\multicolumn{12}{|c|}{$\begin{array}{l}D \\
B\end{array}$}} \\
\hline & & & & & & & & & & & \\
\hline \multirow{5}{*}{$\begin{array}{l}\mathrm{n} \\
\mathrm{N} \\
\mathrm{I} \\
\mathrm{S} \\
\mathrm{H} \\
\mathrm{E} \\
\mathrm{D} \\
\end{array}$} & Tonala & 0 & 0 & 0 & 0 & 0 & 0 & 0 & 0 & 0 & 0 \\
\hline & Red Paste & 0 & 0 & 0 & 0 & 0 & 0 & 0 & 0 & 0 & 0 \\
\hline & Black & 0 & 0 & 0 & 0 & 0 & 0 & 0 & 0 & 0 & 0 \\
\hline & Valero & 0 & 0 & 0 & 0 & 0 & 0 & 0 & 0 & 0 & 0 \\
\hline & Flower Pot & 0 & 0 & 0 & 0 & 0 & 0 & 0 & 0 & 0 & 0 \\
\hline \multicolumn{12}{|l|}{$u$} \\
\hline \multirow{2}{*}{\multicolumn{12}{|c|}{$\begin{array}{l}\mathbf{N} \\
\mathbf{G}\end{array}$}} \\
\hline & & & & & & & & & & & \\
\hline \multicolumn{12}{|l|}{$\mathrm{L}$} \\
\hline A & & & & & & & & & & & \\
\hline $\begin{array}{l}\mathrm{Z} \\
\mathrm{E}\end{array}$ & & & & & & & & & & & \\
\hline D & Undecorated & 0 & 0 & 0 & 0 & 0 & 0 & 0 & 0 & 0 & 0 \\
\hline & & & & & & & & & & & \\
\hline G & Olive Jar & 0 & 0 & 0 & 0 & 0 & 0 & 0 & 0 & 0 & 0 \\
\hline $\mathrm{L}$ & Sandy Paste & 0 & 1 & 1 & 1 & 0 & 0 & 0 & 0 & 0 & 3 \\
\hline $\begin{array}{ll}\text { L A } \\
\text { E } 7\end{array}$ & Galera & 1 & 0 & 1 & 0 & 0 & 0 & 0 & 0 & 0 & 2 \\
\hline $\begin{array}{ll}\mathrm{E} 2 & 2 \\
\mathrm{~A} & \mathrm{E}\end{array}$ & Red-brown & 0 & 0 & 0 & 0 & 0 & 0 & 0 & 0 & 0 & 0 \\
\hline D D & Other & 0 & 0 & 0 & 0 & 0 & 0 & 0 & 0 & 0 & 0 \\
\hline & Undecorated & 0 & 0 & 1 & 0 & 0 & 0 & 0 & 0 & 0 & 1 \\
\hline & San Augustin & 0 & 0 & 0 & 0 & 0 & 0 & 0 & 0 & 0 & 0 \\
\hline & Blue on White & 1 & 1 & 2 & 0 & 0 & 1 & 0 & 0 & 0 & 5 \\
\hline & Huejotzingo & 0 & 1 & 0 & 1 & 0 & 0 & 0 & 0 & 0 & 2 \\
\hline$T$ & San Elizario & 0 & 0 & 0 & 0 & 0 & 0 & 0 & 0 & 0 & 0 \\
\hline N & $\begin{array}{l}\text { Thin Brown, Black, \& } \\
\text { Blue }\end{array}$ & 0 & 0 & 0 & 0 & 0 & 0 & 0 & 0 & 0 & 0 \\
\hline G & Monterey & 0 & 0 & 0 & 0 & 0 & 0 & 0 & 0 & 0 & 0 \\
\hline $\begin{array}{l}\mathrm{L} \\
\mathrm{A}\end{array}$ & $\begin{array}{l}\text { Puebla Blue on } \\
\text { White II }\end{array}$ & 0 & 0 & 0 & 0 & 0 & 0 & 0 & 0 & 0 & 0 \\
\hline $\begin{array}{l}Z \\
E\end{array}$ & Other & 0 & 0 & 1 & 0 & 0 & 0 & 0 & 0 & 0 & 1 \\
\hline D & Faience & 0 & 0 & 0 & 0 & 0 & 0 & 0 & 0 & 0 & 0 \\
\hline & Undecorated & 3 & 7 & 10 & 3 & 5 & 3 & 0 & 0 & 0 & 31 \\
\hline & Transfer & 0 & 4 & 3 & 1 & 0 & 1 & 0 & 0 & 0 & 9 \\
\hline & Hand Painted & 0 & 6 & 4 & 0 & 2 & 1 & 0 & 0 & 0 & 13 \\
\hline w & Spatter/Sponge & 0 & 1 & 1 & 0 & 0 & 0 & 0 & 0 & 0 & 2 \\
\hline H & Edged & 1 & 1 & 0 & 1 & 0 & 0 & 1 & 0 & 0 & 4 \\
\hline$T$ & Banded Slip & 0 & 5 & 1 & 0 & 0 & 0 & 1 & 1 & 0 & 8 \\
\hline E & Plain Colored & 0 & 0 & 0 & 0 & 0 & 0 & 0 & 0 & 0 & 0 \\
\hline w & Other & 0 & 0 & 0 & 0 & 0 & 0 & 0 & 0 & 0 & 0 \\
\hline $\begin{array}{l}\mathbf{A} \\
\mathbf{B}\end{array}$ & Porcelain & 0 & 0 & 0 & 0 & 0 & 0 & 0 & 0 & 0 & 0 \\
\hline $\begin{array}{l}\mathrm{R} \\
\mathrm{E}\end{array}$ & Porcelain, European & 0 & 0 & 1 & 0 & 0 & 0 & 0 & 0 & 0 & 1 \\
\hline s & Porcelain, Oriental & 0 & 0 & 0 & 0 & 0 & 0 & 0 & 0 & 0 & 0 \\
\hline s & & & & & & & & & & & \\
\hline $\mathrm{T}$ & & & & & & & & & & & \\
\hline 0 & & & & & & & & & & & \\
\hline $\mathrm{N}$ & & & & & & & & & & & \\
\hline E & & & & & & & & & & & \\
\hline W & Salt Glazed & 0 & 0 & 0 & 0 & 0 & 0 & 0 & 0 & 0 & 0 \\
\hline $\begin{array}{l}\mathbf{A} \\
\mathbf{R}\end{array}$ & Bristol Glaze & 0 & 0 & 0 & 0 & 0 & 0 & 0 & 0 & 0 & 0 \\
\hline $\mathrm{E}$ & Other & 0 & 0 & 0 & 0 & 0 & 0 & 0 & 0 & 0 & 0 \\
\hline & & & & & & & & & & & \\
\hline B & & & & & & & & & & & \\
\hline 1 & & & & & & & & & & & \\
\hline$s$ & & & & & & & & & & & \\
\hline$Q$ & & & & & & & & & & & \\
\hline $\mathrm{E}$ & Painted & 0 & 0 & 0 & 0 & 1 & 0 & 0 & 0 & 0 & 1 \\
\hline & & & & & & & & & & & \\
\hline & & 7 & 27 & 28 & 7 & 8 & 8 & 2 & 2 & 0 & 89 \\
\hline & & & & & & & & & & & \\
\hline
\end{tabular}


Appendix B, continued...

\begin{tabular}{|c|c|c|c|c|c|c|c|c|c|c|c|}
\hline & Ceramic Type & $\begin{array}{c}\text { Level } 1 \\
(0-10) \\
\end{array}$ & $\begin{array}{l}\text { Level } 2 \\
(10-20) \\
\end{array}$ & $\begin{array}{l}\text { Level } 3 \\
(20-30) \\
\end{array}$ & $\begin{array}{l}\text { Level } 4 \\
(30-40) \\
\end{array}$ & $\begin{array}{l}\text { Level } 5 \\
(40-50) \\
\end{array}$ & $\begin{array}{l}\text { Level } 6 \\
(50-60)\end{array}$ & $\begin{array}{l}\text { Level } 7 \\
(60-70) \\
\end{array}$ & $\begin{array}{l}\text { Level } 8 \\
(70-80)\end{array}$ & $\begin{array}{l}\text { Level } 9 \\
(80-90) \\
\end{array}$ & Totals \\
\hline$G$ & & & & & & & & & & & \\
\hline G & & & & & & & & & & & \\
\hline 0 & & & & & & & & & & & \\
\hline 1 & & & & & & & & & & & \\
\hline A & & & & & & & & & & & \\
\hline D & Goliad & 10 & 36 & 32 & 36 & 33 & 33 & 11 & 15 & 4 & 210 \\
\hline $\mathbf{B}$ & & & & & & & & & & & \\
\hline u & & & & & & & & & & & \\
\hline $\mathbf{R}$ & & & & & & & & & & & \\
\hline $\mathbf{N}$ & Tonala & 1 & 1 & 0 & 1 & 0 & 0 & 0 & 0 & 0 & 3 \\
\hline 1 & Red Paste & 0 & 0 & 0 & 0 & 1 & 0 & 0 & 0 & 0 & 1 \\
\hline $\begin{array}{l}\mathrm{S} \\
\mathrm{H}\end{array}$ & Black & 0 & 0 & 0 & 0 & 1 & 0 & 0 & 0 & 0 & 1 \\
\hline $\mathrm{E}$ & Valero & 0 & 1 & 2 & 3 & 2 & 1 & 3 & 0 & 0 & 12 \\
\hline D & Flower Pot & 12 & 19 & 1 & 1 & 0 & 2 & 0 & 0 & 0 & 35 \\
\hline$u$ & & & & & & & & & & & \\
\hline $\mathbf{N}$ & & & & & & & & & & & \\
\hline G & & & & & & & & & & & \\
\hline L & & & & & & & & & & & \\
\hline A & & & & & & & & & & & \\
\hline $\mathrm{E}$ & & & & & & & & & & & \\
\hline $\mathrm{D}$ & Undecorated & 6 & 0 & 0 & 0 & 0 & 0 & 0 & 0 & 0 & 6 \\
\hline G & Olive Jar & 0 & 0 & 0 & 0 & 0 & 1 & 0 & 0 & 0 & 1 \\
\hline L & Sandy Paste & 7 & 15 & 18 & 18 & 10 & 13 & 7 & 1 & 0 & 89 \\
\hline $\begin{array}{ll}L A \\
L 7\end{array}$ & Galera & 7 & 5 & 16 & 13 & 8 & 12 & 5 & 0 & 0 & 66 \\
\hline A E & Red-brown & 0 & 0 & 1 & 0 & 0 & 0 & 0 & 0 & 0 & 1 \\
\hline D D & Other & 2 & 1 & 0 & 0 & 1 & 0 & 0 & 1 & 0 & 5 \\
\hline & Undecorated & 5 & 4 & 8 & 5 & 8 & 10 & 3 & 4 & 0 & 47 \\
\hline & San Augustin & 0 & 1 & 0 & 1 & 3 & 0 & 0 & 0 & 0 & 5 \\
\hline & Blue on White & 3 & 3 & 4 & 2 & 3 & 6 & 2 & 3 & 1 & 27 \\
\hline & Huejotzingo & 1 & 1 & 3 & 3 & 2 & 0 & 0 & 1 & 0 & 11 \\
\hline $\mathrm{T}$ & San Elizario & 1 & 1 & 2 & 3 & 2 & 4 & 1 & 1 & 0 & 15 \\
\hline $\mathrm{N}$ & $\begin{array}{l}\text { Thin Brown, Black, \& } \\
\text { Blue }\end{array}$ & 0 & 1 & 0 & 1 & 0 & 0 & 0 & 0 & 0 & 2 \\
\hline G & Monterey & 2 & 0 & 0 & 5 & 1 & 0 & 0 & 0 & 0 & 8 \\
\hline $\begin{array}{l}\mathrm{L} \\
\mathrm{A}\end{array}$ & $\begin{array}{l}\text { Puebla Blue on } \\
\text { White II }\end{array}$ & 0 & 0 & 0 & 0 & 1 & 0 & 1 & 0 & 0 & 2 \\
\hline $\mathrm{E}$ & Other & 3 & 1 & 3 & 1 & 1 & 1 & 2 & 0 & 0 & 12 \\
\hline D & Faience & 0 & 1 & 2 & 1 & 0 & 0 & 0 & 0 & 0 & 4 \\
\hline & Undecorated & 13 & 44 & 27 & 26 & 17 & 7 & 5 & 2 & 0 & 141 \\
\hline & Transfer & 6 & 12 & 10 & 6 & 1 & 2 & 1 & 0 & 0 & 38 \\
\hline & Hand Painted & 1 & 17 & 7 & 2 & 7 & 2 & 1 & 1 & 0 & 38 \\
\hline w & Spatter/Sponge & 3 & 2 & 2 & 1 & 0 & 0 & 0 & 0 & 0 & 8 \\
\hline H & Edged & 2 & 6 & 2 & 2 & 1 & 1 & 1 & 0 & 0 & 15 \\
\hline $\mathrm{T}$ & Banded Slip & 4 & 17 & 12 & 3 & 1 & 4 & 1 & 1 & 0 & 43 \\
\hline $\mathrm{E}$ & Plain Colored & 3 & 7 & 0 & 0 & 0 & 0 & 0 & 0 & 0 & 10 \\
\hline w & Other & 2 & 0 & 0 & 5 & 0 & 0 & 0 & 0 & 0 & 7 \\
\hline A & Porcelain & 0 & 0 & 1 & 0 & 0 & 0 & 0 & 0 & 0 & 1 \\
\hline $\mathrm{E}$ & Porcelain, European & 1 & 11 & 1 & 0 & 0 & 0 & 0 & 0 & 0 & 13 \\
\hline $\mathrm{s}$ & Porcelain, Oriental & 1 & 0 & 0 & 0 & 1 & 0 & 0 & 0 & 0 & 2 \\
\hline & & & & & & & & & & & 0 \\
\hline $\begin{array}{l}\mathrm{S} \\
\mathrm{T}\end{array}$ & & & & & & & & & & & 0 \\
\hline 0 & & & & & & & & & & & 0 \\
\hline $\mathbf{N}$ & & & & & & & & & & & 0 \\
\hline$E$ & & & & & & & & & & & 0 \\
\hline W & Salt Glazed & 1 & 1 & 1 & 0 & 0 & 1 & 0 & 0 & 0 & 4 \\
\hline $\mathbf{R}$ & Bristol Glaze & 0 & 0 & 0 & 0 & 1 & 0 & 0 & 0 & 0 & 1 \\
\hline$E$ & Other & 1 & 1 & 1 & 1 & 0 & 0 & 0 & 0 & 0 & 4 \\
\hline & & & & & & & & & & & 0 \\
\hline B & & & & & & & & & & & 0 \\
\hline 1 & & & & & & & & & & & 0 \\
\hline $\mathrm{s}$ & & & & & & & & & & & 0 \\
\hline u & & & & & & & & & & & 0 \\
\hline $\mathrm{E}$ & Painted & 0 & 0 & 0 & 0 & 1 & 0 & 0 & 0 & 0 & 1 \\
\hline & & & & & & & & & & & \\
\hline & & 98 & 209 & 156 & 140 & 107 & 100 & 44 & 30 & 5 & 889 \\
\hline
\end{tabular}



Appendix C

Faunal Remains 
Appendix C

\begin{tabular}{|c|c|c|c|c|c|c|c|}
\hline Lot & Unit & cm Below Surface & Count & Weight & Total Count & Total Weight & Wall Totals \\
\hline 001 & A & $0-10$ & 45 & 78.14 & & & \\
\hline 003 & A & $10-20$ & 41 & 74.60 & & & \\
\hline 006 & A & $20-30$ & 74 & 44.88 & & & \\
\hline 010 & A & $40-50$ & 8 & 12.64 & & & \\
\hline 013 & $A$ & $50-60$ & 4 & 8.16 & & & \\
\hline 016 & A & $60-70$ & 1 & 2.47 & & & \\
\hline \multirow[t]{2}{*}{018} & A & $70-80$ & 1 & 0.92 & & & \\
\hline & & & & & 174 & 221.81 & \\
\hline 002 & $B$ & $0-10$ & 49 & 82.85 & & & \\
\hline 002 & $B$ & $0-10$ & 33 & 53.58 & & & \\
\hline 004 & $B$ & $10-20$ & 31 & 69.59 & & & \\
\hline 007 & $\mathrm{~B}$ & $20-30$ & 41 & 64.69 & & & \\
\hline 009 & $B$ & $30-40$ & 25 & 44.88 & & & \\
\hline \multirow[t]{2}{*}{014} & $\mathrm{~B}$ & $50-60$ & 6 & 3.52 & & & \\
\hline & & & & & 185 & 319.11 & \\
\hline 110 & 16 & $0-10$ & 36 & 82.32 & & & \\
\hline 112 & 16 & $10-20$ & 15 & 95.39 & & & \\
\hline 121 & 16 & $30-40$ & 8 & 46.24 & & & \\
\hline 122 & 16 & $40-50$ & 6 & 45.78 & & & \\
\hline \multirow[t]{2}{*}{124} & 16 & $50-60$ & 6 & 8.58 & & & \\
\hline & & & & & 71 & 278.31 & \\
\hline 82 & 13 & $0-10$ & 27 & 31.26 & & & \\
\hline 85 & 13 & $10-20$ & 76 & 112.94 & & & \\
\hline 91 & 13 & $20-30$ & 17 & 16.19 & & & \\
\hline 97 & 13 & $30-40$ & 8 & 30.19 & & & \\
\hline 108 & 13 & $40-50$ & 32 & 45.83 & & & \\
\hline 123 & 13 & $50-60$ & 5 & 5.92 & & & \\
\hline \multirow{2}{*}{126} & 13 & $60-70$ & 7 & 12.89 & & & \\
\hline & & & & & 172 & 255.22 & \\
\hline 48 & 9 & $0-10$ & 11 & 10.83 & & & \\
\hline 50 & 9 & $0-10$ & 1 & 0.84 & & & \\
\hline 52 & 9 & $10-20$ & 62 & 47.06 & & & \\
\hline 63 & 9 & $20-30$ & 58 & 53.82 & & & \\
\hline 68 & 9 & $30-40$ & 122 & 172.38 & & & \\
\hline 94 & 9 & $40-50$ & 49 & 245.34 & & & \\
\hline 96 & 9 & $50-60$ & 13 & 46.40 & & & \\
\hline 100 & 9 & $60-70$ & 7 & 8.51 & & & \\
\hline \multirow[t]{2}{*}{104} & 9 & $70-80$ & 1 & 0.37 & & & \\
\hline & & & & & 324 & 585.55 & \\
\hline 44 & 8 & $0-10$ & 3 & 4.91 & & & \\
\hline 47 & 8 & $0-10$ & 9 & 15.15 & & & \\
\hline 49 & 8 & $0-20$ & 12 & 31.04 & & & \\
\hline $49 b$ & 8 & $0-20$ & 1 & 2.15 & & & \\
\hline 54 & 8 & $20-30$ & 47 & 64.85 & & & \\
\hline 59 & 8 & $30-40$ & 10 & 8.63 & & & \\
\hline $59 a$ & 8 & $30-40$ & 13 & 23.25 & & & \\
\hline $59 c$ & 8 & $30-40$ & 24 & 20.67 & & & \\
\hline $65 a$ & 8 & $40-50$ & 49 & 127.77 & & & \\
\hline $65 b$ & 8 & $40-50$ & 17 & 24.31 & & & \\
\hline 66 & 8 & $50-60$ & 21 & 44.17 & & & \\
\hline 74 & 8 & $60-70$ & 17 & 33.34 & & & \\
\hline \multirow[t]{2}{*}{79} & 8 & $70-80$ & 13 & 19.46 & & & \\
\hline & & & & & 236 & 419.70 & \\
\hline
\end{tabular}


Appendix C, continued...

\begin{tabular}{|c|c|c|c|c|c|c|c|c|}
\hline Lot & Unit & $\mathrm{cm}$ Below Surface & Count & Weight & Total Count & Total Weight & \multicolumn{2}{|c|}{ Wall Totals } \\
\hline 40 & 7 & $10-20$ & 21 & 37.27 & & & & \\
\hline 43 & 7 & $20-30$ & 27 & 147.24 & & & & \\
\hline 45 & 7 & $30-40$ & 63 & 113.75 & & & & \\
\hline 51 & 7 & $40-50$ & 57 & 84.77 & & & & \\
\hline 53 & 7 & $50-60$ & 49 & 159.87 & & & & \\
\hline 58 & 7 & $60-70$ & 34 & 69.25 & & & & \\
\hline 61 & 7 & $70-80$ & 16 & 71.11 & & & & \\
\hline \multirow[t]{2}{*}{67} & 7 & $80-90$ & 2 & 3.03 & & & & \\
\hline & & & & & 269 & 686.29 & & \\
\hline 88 & 15 & $0-10$ & 1 & 0.18 & & & & \\
\hline 89 & 15 & $10-20$ & 4 & 5.01 & & & & \\
\hline 92 & 15 & $20-30$ & 15 & 59.32 & & & & \\
\hline 99 & 15 & $30-40$ & 5 & 5.42 & & & & \\
\hline 101 & 15 & $40-50$ & 15 & 13.49 & & & & \\
\hline 106 & 15 & $50-60$ & 3 & 1.75 & & & & \\
\hline 109 & 15 & $60-70$ & 1 & 9.77 & & & & \\
\hline \multirow[t]{2}{*}{119} & 15 & $0-80$ & 1 & 3.82 & & & & \\
\hline & & & & & 45 & 98.76 & & \\
\hline 55 & 10 & $0-10$ & 7 & 2.74 & & & & \\
\hline 57 & 10 & $10-20$ & 40 & 42.66 & & & & \\
\hline 60 & 10 & $20-30$ & 9 & 32.10 & & & & \\
\hline 70 & 10 & $30-40$ & 5 & 34.04 & & & & \\
\hline 72 & 10 & $40-50$ & 10 & 10.78 & & & & \\
\hline 76 & 10 & $50-60$ & 1 & 3.62 & & & & \\
\hline \multirow[t]{2}{*}{78} & 10 & $60-70$ & 6 & 7.54 & & & & \\
\hline & & & & & 78 & 133.48 & & \\
\hline 1 & 1 & $0-10$ & 87 & 66.92 & & & & \\
\hline 3 & 1 & $10-20$ & 148 & 234.20 & & & & \\
\hline 6 & 1 & $20-30$ & 144 & 165.12 & & & & \\
\hline 7 & 1 & $30-40$ & 91 & 136.51 & & & & \\
\hline 14 & 1 & $40-50$ & 74 & 82.64 & & & & \\
\hline 17 & 1 & $50-60$ & 79 & 97.02 & & & & \\
\hline \multirow[t]{2}{*}{19} & 1 & $60-70$ & 20 & 27.13 & & & \multicolumn{2}{|c|}{ Wall 1 and 2 Totals: } \\
\hline & & & & & 643 & 809.54 & 2197 & 3807.77 \\
\hline 62 & 11 & $0-10$ & 1 & 1.12 & & & & \\
\hline 64 & 11 & $10-20$ & 65 & 123.30 & & & & \\
\hline 69 & 11 & $20-30$ & 13 & 49.39 & & & & \\
\hline 71 & 11 & $30-40$ & 127 & 200.95 & & & & \\
\hline 73 & 11 & $40-50$ & 75 & 126.36 & & & & \\
\hline 75 & 11 & $50-60$ & 102 & 96.21 & & & & \\
\hline 77 & 11 & $60-70$ & 12 & 45.22 & & & & \\
\hline \multirow[t]{2}{*}{80} & 11 & $70-80$ & 34 & 47.92 & & & & \\
\hline & & & & & 429 & 690.47 & & \\
\hline 84 & 14 & $0-10$ & 23 & 38.22 & & & & \\
\hline 87 & 14 & $10-20$ & 223 & 283.62 & & & & \\
\hline 90 & 14 & $20-30$ & 260 & 433.51 & & & & \\
\hline 95 & 14 & $30-40$ & 183 & 341.87 & & & & \\
\hline 98 & 14 & $40-50$ & 105 & 243.78 & & & & \\
\hline 102 & 14 & $50-60$ & 103 & 441.09 & & & & \\
\hline 105 & 14 & $60-70$ & 93 & 310.62 & & & & \\
\hline \multirow[t]{2}{*}{107} & 14 & $70-80$ & 78 & 272.35 & & & & \\
\hline & & & & & 1068 & 2365.06 & & \\
\hline
\end{tabular}


Appendix C, continued...

\begin{tabular}{|c|c|c|c|c|c|c|c|c|}
\hline Lot & Unit & cm Below Surface & Count & Weight & Total Count & Total Weight & \multicolumn{2}{|c|}{ Wall Totals } \\
\hline 2 & 2 & $0-10$ & 7 & 6.81 & & & & \\
\hline 4 & 2 & $10-20$ & 58 & 43.09 & & & & \\
\hline 5 & 2 & $20-30$ & 62 & 82.87 & & & & \\
\hline 8 & 2 & $30-40$ & 94 & 275.04 & & & & \\
\hline 113 & 2 & $30-40$ & 28 & 78.16 & & & & \\
\hline 114 & 2 & $40-50$ & 5 & 0.48 & & & & \\
\hline 116 & 2 & $50-60$ & 23 & 29.83 & & & & \\
\hline \multirow[t]{2}{*}{118} & 2 & $60-70$ & 12 & 27.99 & & & & \\
\hline & & & & & 289 & 544.27 & & \\
\hline 81 & 12 & $0-10$ & 7 & 60.70 & & & & \\
\hline 86 & 12 & $0-10$ & 22 & 23.59 & & & & \\
\hline 93 & 12 & $10-20$ & 11 & 73.21 & & & & \\
\hline 103 & 12 & $20-30$ & 15 & 149.10 & & & & \\
\hline 117 & 12 & $30-40$ & 116 & 191.63 & & & & \\
\hline 125 & 12 & $40-50$ & 69 & 64.39 & & & & \\
\hline 128 & 12 & $50-60$ & 242 & 578.14 & & & & \\
\hline 129 & 12 & $50-60$ & 61 & 117.73 & & & & \\
\hline \multirow[t]{2}{*}{132} & 12 & $70-80$ & 18 & 43.27 & & & & \\
\hline & & & & & 561 & 1301.76 & & \\
\hline 18 & 3 & $0-10$ & 20 & 8.85 & & & & \\
\hline 23 & 3 & $0-10$ & 25 & 15.26 & & & & \\
\hline 25 & 3 & $10-20$ & 3 & 6.25 & & & & \\
\hline 29 & 3 & $20-30$ & 59 & 91.20 & & & & \\
\hline 32 & 3 & $30-35$ & 2 & 1.06 & & & & \\
\hline $32 a$ & 3 & $30-35$ & 8 & 14.40 & & & & \\
\hline 37 & 3 & $35-45$ & 327 & 538.01 & & & & \\
\hline 42 & 3 & $45-55$ & 187 & 321.22 & & & & \\
\hline 56 & 3 & $55-60$ & 554 & 1113.56 & & & & \\
\hline 130 & 3 & $60-70$ & 71 & 129.11 & & & & \\
\hline 131 & 3 & $70-80$ & 36 & 87.09 & & & & \\
\hline \multirow[t]{2}{*}{133} & 3 & $80-90$ & 31 & 58.62 & & & & \\
\hline & & & & & 1323 & 2384.63 & & \\
\hline 20 & 4 & $0-10$ & 16 & 8.00 & & & & \\
\hline $26 a$ & 4 & $10-20$ & 22 & 53.74 & & & & \\
\hline $26 b$ & 4 & $10-20$ & 6 & 2.37 & & & & \\
\hline 30 & 4 & $20-30$ & 26 & 31.94 & & & & \\
\hline 33 & 4 & $30-40$ & 44 & 34.07 & & & & \\
\hline 39 & 4 & $40-50$ & 15 & 23.44 & & & & \\
\hline \multirow[t]{2}{*}{46} & 4 & $50-60$ & 9 & 9.16 & & & \multicolumn{2}{|c|}{ Wall 3 and 4 Totals: } \\
\hline & & & & & 138 & 162.72 & 3808 & 7448.91 \\
\hline 10 & 5 & $0-10$ & 10 & 29.58 & & & & \\
\hline 13 & 5 & $10-20$ & 28 & 31.25 & & & & \\
\hline 15 & 5 & $20-30$ & 43 & 65.01 & & & & \\
\hline 21 & 5 & $30-40$ & 26 & 11.24 & & & & \\
\hline $24 a$ & 5 & $40-50$ & 27 & 49.19 & & & & \\
\hline $24 b$ & 5 & $40-50$ & 1 & 3.35 & & & & \\
\hline 28 & 5 & $50-60$ & 7 & 3.13 & & & & \\
\hline $35 a$ & 5 & $60-70$ & 6 & 26.44 & & & & \\
\hline $36 a$ & 5 & $70-80$ & 4 & 6.81 & & & & \\
\hline $35 b$ & 5 & $0-80$ & 3 & 21.92 & & & & \\
\hline & & & & & 155 & 247.92 & & \\
\hline
\end{tabular}


Appendix C, continued...

\begin{tabular}{|c|c|c|c|c|c|c|c|c|}
\hline Lot & Unit & cm Below Surface & Count & Weight & Total Count & Total Weight & \multicolumn{2}{|c|}{ Wall Totals } \\
\hline & & & & & 155 & 247.92 & & \\
\hline 12 & 6 & $0-10$ & 19 & 46.16 & & & & \\
\hline 16 & 6 & $10-20$ & 86 & 162.94 & & & & \\
\hline 22 & 6 & $20-30$ & 49 & 61.19 & & & & \\
\hline 27 & 6 & $30-40$ & 43 & 31.57 & & & & \\
\hline 31 & 6 & $40-50$ & 8 & 17.68 & & & & \\
\hline 34 & 6 & $50-60$ & 5 & 6.25 & & & & \\
\hline 41 & 6 & $60-70$ & 2 & 5.93 & & & \multicolumn{2}{|c|}{ Wall 5 Totals: } \\
\hline & & & & & 212 & 331.72 & 367 & 579.64 \\
\hline \multicolumn{8}{|c|}{ Miscellaneous Collection: } & \\
\hline 137 & W2 & $0-80$ & 8 & 50.33 & & & & \\
\hline 136 & W4 & $0-80$ & 99 & 645.39 & & & & \\
\hline \multirow[t]{2}{*}{135} & W5 & $0-80$ & 3 & 66.25 & & & & \\
\hline & & & & & 110 & 761.97 & & \\
\hline
\end{tabular}

